\title{
Surgery in metastatic breast cancer
}

Citation for published version (APA):

Ruiterkamp, J. (2012). Surgery in metastatic breast cancer. [Doctoral Thesis, Maastricht University]. Maastricht University. https://doi.org/10.26481/dis.20120621jr

Document status and date:

Published: 01/01/2012

DOI:

10.26481/dis.20120621jr

Document Version:

Publisher's PDF, also known as Version of record

\section{Please check the document version of this publication:}

- A submitted manuscript is the version of the article upon submission and before peer-review. There can be important differences between the submitted version and the official published version of record.

People interested in the research are advised to contact the author for the final version of the publication, or visit the DOI to the publisher's website.

- The final author version and the galley proof are versions of the publication after peer review.

- The final published version features the final layout of the paper including the volume, issue and page numbers.

Link to publication

\footnotetext{
General rights rights.

- You may freely distribute the URL identifying the publication in the public portal. please follow below link for the End User Agreement:

www.umlib.nl/taverne-license

Take down policy

If you believe that this document breaches copyright please contact us at:

repository@maastrichtuniversity.nl

providing details and we will investigate your claim.
}

Copyright and moral rights for the publications made accessible in the public portal are retained by the authors and/or other copyright owners and it is a condition of accessing publications that users recognise and abide by the legal requirements associated with these

- Users may download and print one copy of any publication from the public portal for the purpose of private study or research.

- You may not further distribute the material or use it for any profit-making activity or commercial gain

If the publication is distributed under the terms of Article $25 \mathrm{fa}$ of the Dutch Copyright Act, indicated by the "Taverne" license above, 


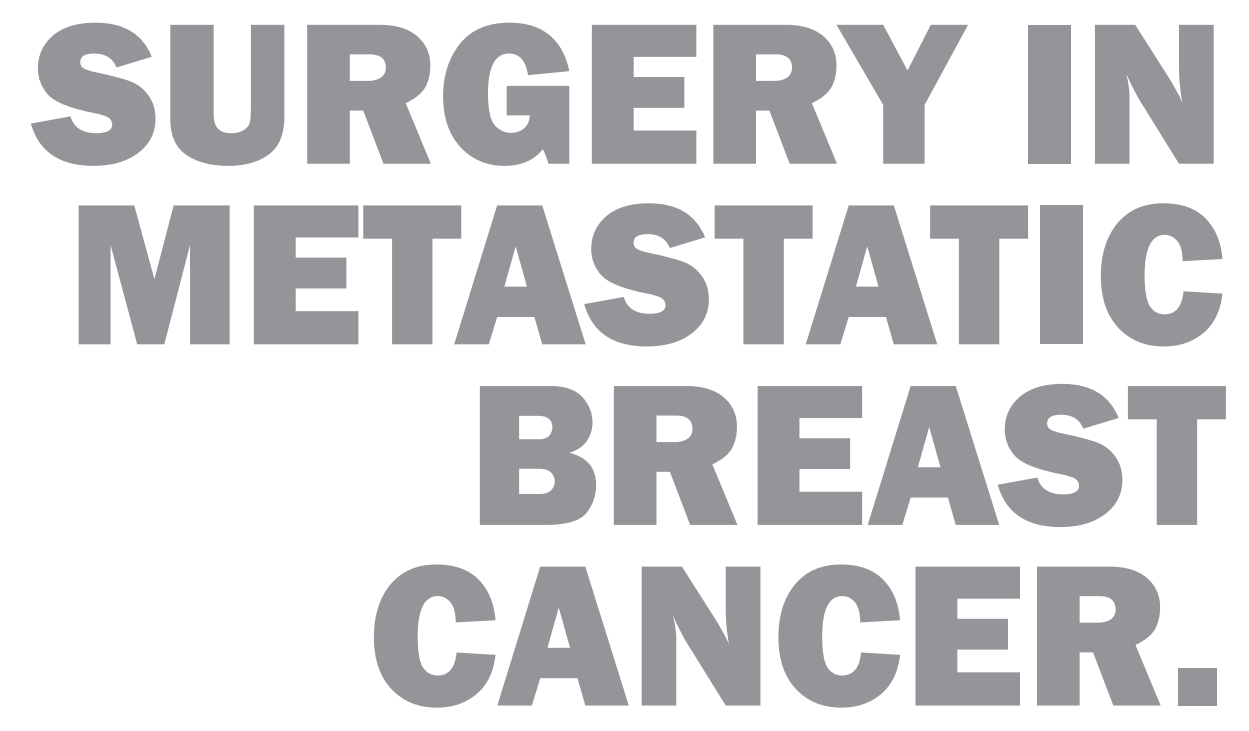


(C) Jetske Ruiterkamp, Maastricht 2012

Cover design: Marcia Teeuwen

Layout: Tiny Wouters

Production: Buijten \& Schipperheijn

ISBN: 978-90-9026789-0

Printing of this thesis was financially supported by:

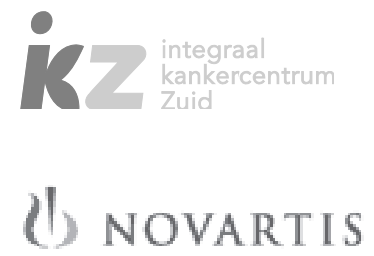

Roche

SANOFI ONCOLOGY 


\section{SURGERY IN}
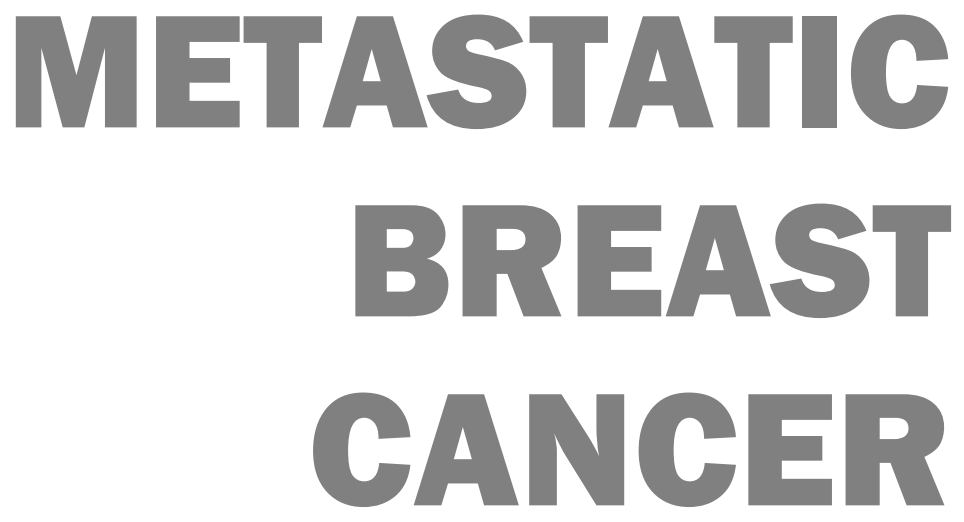

Proefschrift

ter verkrijging van de graad van doctor aan de Universiteit Maastricht, op gezag van de Rector Magnificus, Prof. mr. G.P.M.F. Mols volgens het besluit van het College van Decanen, in het openbaar te verdedigen op donderdag 21 juni 2012 12:00 uur

door

Jetske Ruiterkamp 


\section{Promotor}

Prof. dr. V.C.G. Tjan-Heijnen

\section{Copromotores}

Dr. M.F. Ernst

Dr. A.C. Voogd

Beoordelingscommissie

Prof. dr. M.F. von Meyenfeldt (voorzitter)

Dr. P.S.G.J. Hupperets

Prof. dr. M.H. Prins 


\section{Contents}

Chapter 1 Introduction and outline of this thesis 7

Chapter 2 Improved survival of patients with primary distant metastatic $\quad 15$ breast cancer in the period of $1995-2008$. A nationwide population-based study in the Netherlands

Chapter 3 Surgical resection of the primary tumor is associated with improved survival in patients with metastatic breast cancer at diagnosis

Chapter 4 Presence of symptoms and timing of surgery do not affect the prognosis of patients with primary metastatic breast cancer

Chapter 5 Impact of breast surgery on survival in patients with distant 55 metastases at initial presentation. A systematic review of the literature

Chapter 6 Systemic therapy with or without up front surgery of the primary 69 tumor in breast cancer patients with distant metastatic disease at initial presentation. SUBMIT study protocol

Chapter 7 The role of surgery in breast cancer liver and lung metastases

Chapter 8 Summary, conclusions and future perspectives

Nederlandse samenvatting, conclusies en toekomstige ontwikkelingen

Dankwoord

Curriculum vitae 



\section{CHAPTER 1}

INTRODUCTION AND OUTLINE OF THIS THESIS 
8 Chapter 1 


\section{Breast cancer and metastases}

Breast cancer is a worldwide health problem affecting more than 1 million women annually. ${ }^{1,2}$ It is the most frequently diagnosed cancer and the leading cause of cancer death in females; in 2008 it accounted for $23 \%$ of the total new cancer cases worldwide. ${ }^{2}$ The standard of care for the treatment of early breast cancer consists of resection of the breast tumor by breast conserving surgery or mastectomy, combined with a (staging) procedure of the axilla, and (if indicated) followed by radiotherapy and adjuvant systemic therapy. Ultimately, 25-30\% of all patients treated for early stage breast cancer will develop distant metastases. Sites of metastases in these patients with so called "secondary metastatic breast cancer" are bone (85\%), liver (40$50 \%)$, pleura (20\%), lung (15-25\%) and brain (6-16\%). ${ }^{3}$ Metastatic breast cancer is a heterogeneous disease with respect to clinical presentation, ranging from patients with a solitary metastatic site to those with diffuse and multiple organ involvement. ${ }^{4}$ Once metastatic disease is diagnosed, prognosis becomes rather poor, with a median survival time between 18 and 24 months. ${ }^{5}$ Factors associated with a good prognosis in secondary metastatic breast cancer are a long disease-free interval, a positive estrogen receptor status of the primary tumor, a dominant metastatic site in bone or soft tissue and a limited volume of metastases. During the last fifteen years, important changes have taken place in the systemic treatment of patients with metastasized breast cancer, such as the introduction of taxanes in the late nineties and aromatase inhibitors and targeted therapy like trastuzumab in the beginning of the twenty-first century. A systematic review of trials has demonstrated that increased efficacy of chemotherapy and targeted treatments have resulted in important improvements in the survival of patients with metastatic or recurrent disease, especially in patients with HER2 positive disease. ${ }^{6}$

A small part of the patients with breast cancer are diagnosed with distant metastases at the same time as the diagnosis of the breast tumor, which is referred to as "primary metastatic breast cancer". It concerns approximately $5 \%$ of all breast cancer patients. ${ }^{7}$ Because metastatic breast cancer is considered to be an incurable disease, the aim of the treatment is to provide palliation and prolongation of survival. Patients may be treated with hormonal treatment, chemotherapy, targeted therapy and/or radiotherapy. Usually, breast surgery is reserved for patients whose tumor is symptomatic, to obtain local control and avoid uncontrolled chest wall disease. ${ }^{8}$

\section{Surgery in metastatic breast cancer}

Until recently, it was generally accepted that once metastases have occurred, aggressive local breast therapy provides no survival advantage and should not be pursued in patients with primary metastatic breast cancer. ${ }^{9}$ However, the assumption 
that local therapy provides no survival benefit has never been sustained with randomized clinical trials. ${ }^{10}$

Since 2008, seven studies were published on surgery of the breast tumor in patients with primary distant metastatic breast cancer. Six of them indicated that these patients had a survival benefit from resection of the breast tumor. ${ }^{9-15}$ This insight may change the perspective on the treatment of primary distant metastatic breast cancer and is further examined in this thesis.

Moreover, if breast surgery in patients with primary distant metastatic disease may appear to improve survival, the question rises whether this also accounts for resection of breast cancer metastases in secondary metastatic breast cancer. Palliative antitumor treatment in these patients is considered to be effective if the size of metastatic tumor deposits is reduced at treatment evaluation. To obtain this result, several courses of chemotherapy and/or targeted therapy or several months of hormonal therapy is needed. In theory, a quicker result might be obtained by resection of oligometastatic disease. Therefore, metastasectomy is nowadays increasingly considered for patients who have limited liver and lung metastases, in order to prolong survival in selected patients who are fit enough to undergo an operation. Surgery and other local therapeutic approaches like radiofrequency ablation are, however, still not commonly offered to these patients, and only a few (retrospective) studies refer to the subject. 


\section{Outline of this thesis}

This thesis discusses trends in the prognosis of patients with primary metastatic breast cancer and the impact of breast surgery on survival in these patients. It also provides an overview on metastasectomy of liver and lung metastases in breast cancer.

Chapter 2 reviews the prognosis of patients with primary distant metastatic breast cancer in the Netherlands. Patients were selected from the population based Netherlands Cancer Registry. Information on histology and cytopathology was provided by the nationwide Dutch network, called PALGA and trained registry personnel from the Netherlands Cancer Registry collected data on patient and tumor characteristics, diagnosis, staging and treatment. Between 1995 and 2008, 160,595 new patients were diagnosed with invasive breast cancer. Of these patients, 8,031 (5.0\%) had distant metastases at diagnosis. Patients were divided into three periods, based on the year of diagnosis of their disease. Information on age at time of diagnosis and size of the primary tumor was recorded. Additionally, information on type of treatment, including systemic treatment, locoregional radiotherapy and surgery of the primary tumor was collected.

A population-based study was conducted in the South of the Netherlands and is presented in chapter $\mathbf{3}$. In this study the impact of surgical resection of the primary tumor on survival in patients with primary distant metastatic disease was investigated, also taking into account the presence of comorbidity. The Eindhoven Cancer Registry (ECR) of the Comprehensive Cancer Centre South was used to obtain information on all patients diagnosed with primary metastatic breast cancer between 1993 and 2004. The region covered by the ECR comprises 2.3 million inhabitants and 16 general hospitals. Ten hospitals and 2 radiotherapy institutes participate in the ECR. This study included 728 patients $(4.6 \%$ of all patients diagnosed with breast cancer in that period) with distant metastatic disease at initial presentation. This was defined as the diagnosis of metastases within one month after the diagnosis of the breast tumor. Data on primary treatment were recorded, including surgery, locoregional radiotherapy, chemotherapy (with or without targeted therapy) or hormonal therapy, as well as details on the surgical procedure, such as breastconserving surgery, mastectomy and axillary dissection. Information on the dominant site of metastatic disease and the number of organs involved was also collected.

In chapter 4, potential confounders of the effect of a surgical resection of the breast tumor in patients with primary distant metastatic disease, like presence of symptoms of metastases and timing of surgery, are examined, as well as the prognostic effect of surgical margin status on survival. To collect information on these potential confounders and margin status, individual charts of 279 patients with primary 
metastatic breast cancer were reviewed. These patients were derived from the patient group that was used for the previous study (chapter 3). They were selected out of four large teaching hospitals in the South of the Netherlands, diagnosed between 1995 and 2005.

In a systematic review of the literature in chapter 5, studies on surgery of the breast tumor in patients with primary metastatic breast cancer are discussed to weigh the evidence for and against breast surgery with respect to its effect on survival. Ten retrospective studies were analysed in which the use of breast surgery in primary metastatic breast cancer and its impact on survival was examined, including our own population-based study (chapter 4). The hazard ratio's of the studies were pooled to provide an estimate of the overall effect of surgery, and the results and conclusions of the studies were analyzed. Further, literature was explored to look for possible biological mechanisms explaining the findings from clinical studies.

In chapter 6 the protocol of the study "Systemic therapy with or without Up front surgery in Breast cancer patients with distant Metastases at Initial presenTation" (SUBMIT) is presented. This randomized controlled trial will be performed to assess whether breast surgery in patients with primary distant metastatic breast cancer will improve survival. Patients with primary distant metastatic breast cancer, with no prior treatment of the breast cancer, who are 18 years or older are eligible. Important exclusion criteria are prior invasive breast cancer and synchronous bilateral breast cancer. Patients will either be randomized for up front surgery of the breast tumor followed by systemic therapy, or for systemic therapy followed by delayed local treatment of the breast tumor if indicated. The primary endpoint is 2-year survival. Quality of life and local tumor control are the most important secondary endpoints. Approximately 500 patients are needed, with a total accrual time of 60 months. More than 25 hospitals in the Netherlands will participate in this multicenter study.

In general, patients with secondary metastatic breast cancer are treated with systemic therapy, whereas metastasectomy of liver and lung metastases might improve overall survival of these patients. In order to analyze the effect of metastasectomy of liver and lung metastases on survival, an overview of the literature on this subject is given in chapter 7. A systematic review was conducted to weigh the evidence for and against metastasectomy. The results and conclusions of reports on metastasectomy in hepatic metastases, minimally invasive techniques for liver metastases and studies regarding metastasectomy in patients with pulmonary metastases were analyzed and compared. 


\section{References}

1. Stuckey A. Breast cancer: epidemiology and risk factors. Clin Obstet Gynecol. 2011;54:96-102

2. Jamal A, Fray F, Center MM, Ferlay J, Ward E, Forman D. Global cancer statistics. CA Cancer J Clin. 2011;61:69-90

3. Giordano SH, Buzdar AU, Smith TL, Kau SW, Yang Y, Hortobagyi GN. Is breast cancer survival improving? Trends in survival for patients with recurrence breast cancer diagnosed form 1974 through 2000. Cancer. 2004;100:44-52

4. Pagani O, Senkus E, Wood W, Colleoni M, Cufer T, Kyriakides S, Costa A, Winer EP, Cardoso F. International guidelines for management of metastatic breast cancer: Can metastatic breast cancer be cured? J Natl Cancer Inst. 2010;102:456-463

5. Dawood S, Broglio K, Ensor J, Hortobagyi GN, Giordano SH. Survival differences among women with de novo stage IV and relapsed breast cancer. Ann Oncol. 2010;21:2169-2174

6. Mauri D, Polyzos NP, Salanti G, Pavlidis N, loannidis JPA. Multiple-treatments meta-analysis of chemotherapy and targeted therapies in advanced breast cancer. J Natl Cancer Inst. 2008;100: 1780-1791

7. Ernst MF, van de Poll-Franse LV, Roukema JA, Coebergh JW, van Gestel CM, Vreugdenhil G, Louwman MJ, Voogd AC. Trends in the prognosis of patients with primary metastatic breast cancer diagnosed between 1975 and 2002. Breast. 2007;16:344-351

8. Hazard HW, Gorla SR, Scholtens D, Kiel K, Gradishar WJ, Khan SA. Surgical resection of the primary tumor, chest wall control, and survival in women with metastatic breast cancer. Cancer. 2008;113:2011-2019

9. Khan SA, Stewart AK, Morrow M. Does aggressive local therapy improve survival in metastatic breast cancer? Surgery. 2002;132:620-627

10. Rapiti E, Verkooijen HM, Vlastos G, Fioretta G, Neyroud-Caspar I, Sappino AP, et al. Complete excision of primary breast tumor improves survivial of patients with metastatic breast cancer at diagnosis. J Clin Oncol. 2006; 24:2743-2749

11. Babiera GV, Rao R, Feng L, Meric-Bernstam F, Kuerer HM, Singletary SE, Hunt KK, Ross MI, Gwyn KM, Feig BW, Ames FC, Hortobagyi GN. Effect of primary tumor extirpation in breast cancer patients who present with stage IV disease and an intact primary tumor. Ann Surg Oncol. 2005;13:776-782

12. Fields RC, Jeffe DB, Trinkaus K, Zhang $Q$, Arthur C, Aft R, Dietz JR, Eberlein TJ, Gillanders WE, Margenthaler JA. Surgical resection of the primary tumor is associated with increased long-term survival in patients with stage IV breast cancer after controlling for site of metastasis. Ann Surg Oncol. 2007; 14:3345-3351

13. Gnerlich J, Jeffe DB, Deshpande AD, Beers C, Zander C, Margenthaler JA. Surgical removal of the primary tumor increases overall survival in patients with metastatic breast cancer. Analysis of the 1988-2003 SEER data. Ann Surg Oncol. 2007;14:2187-2194

14. Blanchard DK, Shetty PB, Hilsenbeck SG, Elledge RM. Association of surgery with improved survival in stage IV breast cancer patients. Ann Surg. 2008;247:732-738

15. Cady B, Nathan NR, Michaelson JS, Golshan M, Smith BL. Matched pair analyses of stage IV breast cancer with or without resection of primary breast site. Ann Surg Oncol. 2008;15:3384-3395 


\title{
CHAPTER 2

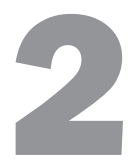

IMPROVED SURVIVAL OF PATIENTS WITH PRIMARY DISTANT METASTATIC BREAST CANCER IN THE PERIOD OF 1995 - 2008

\author{
A nationwide population-based study \\ in the Netherlands
}

\author{
J Ruiterkamp \\ MF Ernst \\ L de Munck \\ $M$ van der Heiden-van der Loo \\ E Bastiaannet \\ LV van de Poll-Franse \\ $\mathrm{K}$ Bosscha \\ VCG Tjan-Heijnen \\ AC Voogd
}




\section{Abstract}

\section{Objective}

In this study changes in prognosis for more than 8000 patients with primary distant metastatic breast cancer were analyzed, using nation-wide data of the Netherlands Cancer Registry. Besides the role of systemic treatment, the effect of surgery of the primary tumor was evaluated.

\section{Methods}

Between 1995 and 2008, 160,595 new patients were diagnosed with invasive breast cancer. Of these patients, $8,031(5.0 \%)$ had distant metastases at diagnosis. Patients were divided into three periods, based on the year of diagnosis of their disease.

\section{Results}

The median survival was 1.42 years for patients diagnosed in the period 1995-1999, 1.61 years in the period 2000-2004 and 1.95 years in the period 2005-2008. The improvement of the median survival was most pronounced for patients younger than 50 years. Patients receiving systemic treatment, loco-regional radiotherapy or breast surgery had a significantly lower risk of death compared to patients not receiving these treatments.

\section{Conclusions}

An improvement of 6 months is observed in the median survival of patients with primary distant metastatic breast cancer between 1995 and 2008. The increased efficacy of chemotherapy and the introduction of targeted treatments are the most likely explanations for this improvement, which was most marked for younger patients. 


\section{Introduction}

Approximately $3-10 \%$ of all patients with breast cancer have distant metastases at initial presentation, and this proportion has decreased only slightly during the last three decades. ${ }^{1,2}$ As in general metastatic breast cancer cannot be cured, patients receive palliative treatment. These include hormonal treatment, chemotherapy and targeted therapy. Local treatment of the primary tumor is usually not part of the standard therapy and is only recommended in case of symptomatic local disease.

During the last fifteen years, important changes have taken place concerning systemic treatment for patients with metastasized breast cancer, such as the introduction of taxanes in the late nineties and aromatase inhibitors and targeted therapy like trastuzumab in the beginning of the twenty-first century. A systematic review of trials has demonstrated that increased efficacy of chemotherapy and targeted treatments have resulted in important improvements in the survival of patients with metastatic or recurrent disease. ${ }^{3}$ It would be interesting to know whether these improvements have also taken place in the general population among the patients with primary distant metastatic breast cancer, treated in routine clinical practice outside clinical trials.

In a previous study we reported an increased survival in the Netherlands of patients with primary metastatic breast cancer. In this study, which was based on 1,089 patients diagnosed in South-East Netherlands in the period 1975-2002, the median survival remained unchanged between 1975 and 1984, but increased from 17 months for the patients diagnosed in the period 1985-1994 to 20.5 months for those diagnosed in the period 1995-2002. ${ }^{4}$

In the current study, we analyzed the changes in prognosis for more than 8,000 patients with primary distant metastatic breast cancer diagnosed between 1995 and 2008 and followed until 2010, using nation-wide data of the Netherlands Cancer Registry. As described above, surgery of the primary tumor is not standard treatment in these patients, though several retrospective studies have shown an improvement in overall survival in patients who have received breast surgery. ${ }^{5-11}$ Therefore, we also analyzed the impact of surgical resection of the primary breast tumor, besides the role of systemic treatment.

\section{Patients and methods}

\section{Patients}

Patients were selected from the population based Netherlands Cancer Registry. PALGA, the nationwide Dutch network and registry of histo- and cytopathology, regularly submits reports of all diagnosed malignancies to the regional cancer registries. The national hospital discharge databank, which receives discharge 
diagnoses of admitted patients from all Dutch hospitals, completes case ascertainment. Following this notification, trained registry personnel from the Netherlands Cancer Registry collect data on patient and tumor characteristics, diagnosis, staging and treatment. Coding of the items is based on the registration and coding manual of the Dutch Association of Comprehensive Cancer Centers. According to the database the Netherlands Cancer Registry, 160,595 new patients were diagnosed with invasive breast cancer in the period 1995-2008. Of these patients, $8,031(5.0 \%)$ had distant metastases at diagnosis (stage IV disease).

To establish whether improvement of prognosis had taken place, patients were divided into three periods, based on the year of diagnosis of their disease; 1995-1999, 2000-2004 and 2005-2008. The follow-up of these patients was completed until January 1, 2010. Information about the age of the patients at time of diagnosis and tumor size of the primary tumor was recorded. Clinical tumor size was used for patients who did not undergo surgery. Also, information was collected about the type of treatment received by the patients, including systemic treatment, loco-regional radiotherapy and surgery of the primary tumor. No details on the extent and completeness of the surgical procedure were available. Only the first line of systemic therapy was documented by the Netherlands Cancer Registry and information on the type of systemic treatment was only available for the type of treatment (hormone treatment, chemotherapy, targeted treatment), but not for the exact drugs used. Use of targeted treatment has only been documented since 2005.

\section{Statistical analyses}

Survival time was defined as the period between the date of diagnosis and the date of death or January 2010 for the patients who were still alive. Overall survival rates were calculated using the Kaplan-Meier method. The log-rank test was performed to evaluate significant differences between survival curves in univariate analyses. Multivariable analyses were carried out using Cox proportional hazards regression models. The variables inserted into the model were period of diagnosis (2000-2004 and 2005-2008 versus 1995-1999), age at diagnosis (50-69 and 70+ versus $<50$ years), tumor size (T3-4 versus T1-2), surgery of the primary tumor (yes versus no), locoregional radiotherapy of the primary tumor (yes versus no) and the use of systemic treatment (yes versus no). Hazard ratios (HR) with $95 \%$ confidence intervals $(\mathrm{Cl})$ and $P$ values were estimated with respect to the reference category for each covariate. The SAS computer package (version 9.2) was used for all statistical analysis (SAS Institute Inc., Cary, NC, USA, 1999). 


\section{Results}

\section{Patient characteristics}

The proportion of patients with primary metastatic breast cancer (stage IV disease) decreased from $5.3 \%(2,688 / 51,226)$ in the period $1995-1999$, to $5.0 \%(2,916 / 58,679)$ in the period $2000-2004$ and to $4.8 \%(2,427 / 50,690)$ in the period $2005-2008$ $(P=0.003)$. The proportion of patients with a breast tumor of five centimeter or smaller (T1 and T2 classification) increased from 47\% in the period 1995-1999 to 55\% in the period 2005-2008 (Table 2.1). More than $20 \%$ of all patients with stage IV breast cancer were younger than 50 years, $37 \%$ were between 50 and 70 years and $42 \%$ were 70 years or older (Table 2.1). The proportion of patients in the age group of 50 69 year was somewhat higher in the period 2005-2008.

Table 2.1 Characteristics of patients with primary metastatic breast cancer, according to period of diagnosis $(n=8031)$.

\begin{tabular}{|c|c|c|c|c|c|c|c|}
\hline \multirow[t]{3}{*}{ Characteristic } & \multicolumn{6}{|c|}{ Period of diagnosis } & \multirow[b]{3}{*}{$P$} \\
\hline & \multicolumn{2}{|c|}{$\begin{array}{c}1995-1999 \\
(n=2688)\end{array}$} & \multicolumn{2}{|c|}{$\begin{array}{c}2000-2004 \\
(n=2916)\end{array}$} & \multicolumn{2}{|c|}{$\begin{array}{c}2005-2008 \\
(n=2427)\end{array}$} & \\
\hline & $n$ & (\%) & $n$ & (\%) & $n$ & (\%) & \\
\hline Age at diagnosis (year) & & & & & & & 0.003 \\
\hline$<50$ & 543 & (20) & 642 & (22) & 519 & (21) & \\
\hline $50-69$ & 961 & (36) & 1065 & (37) & 965 & (40) & \\
\hline $70+$ & 1182 & (44) & 1209 & (41) & 943 & (39) & \\
\hline Tumor size & & & & & & & $<0.0001$ \\
\hline T1-2 & 1098 & (47) & 1275 & (50) & 1198 & (55) & \\
\hline T3-4 & 1233 & (53) & 1286 & (50) & 992 & (45) & \\
\hline Missing & 357 & & 299 & & 237 & & \\
\hline Surgery & & & & & & & $<0.0001$ \\
\hline Yes & 831 & (31) & 810 & (28) & 563 & (23) & \\
\hline No & 1857 & (69) & 2106 & (72) & 1864 & (77) & \\
\hline Radiotherapy & & & & & & & 0.002 \\
\hline Yes & 367 & (14) & 428 & (15) & 278 & (11) & \\
\hline No & 2321 & (86) & 2488 & (85) & 2149 & (89) & \\
\hline Systemic treatment & & & & & & & 0.001 \\
\hline Yes & 2404 & (89) & 2514 & (86) & 2142 & (88) & \\
\hline No & 284 & (11) & 402 & (14) & 285 & (12) & \\
\hline Chemotherapy & & & & & & & 0.001 \\
\hline Yes & 883 & (33) & 1086 & (37) & 906 & (37) & \\
\hline No & 1805 & (67) & 1830 & (63) & 1527 & (63) & \\
\hline Hormonal treatment & & & & & & & 0.001 \\
\hline Yes & 1763 & (66) & 1781 & (61) & 1571 & (65) & \\
\hline No & 925 & (34) & 1135 & (39) & 856 & (35) & \\
\hline Targeted treatment & Not a & lable & Not & lable & & & Not \\
\hline Yes & & & & & 245 & (10) & applicable \\
\hline No & & & & & 2182 & (90) & \\
\hline
\end{tabular}


The proportion of patients receiving first-line systemic therapy remained rather stable during the three periods (Table 2.1). Loco-regional radiotherapy as first-line treatment was administered to $14 \%$ of all patients in the period $1995-1999$, to $15 \%$ in the period 2000-2004 and to $11 \%$ in the period 2005-2008 (Table 2.1). The proportion of patients who underwent a resection of the breast tumor (either ablation of the breast or lumpectomy, with or without axillary lymph node dissection) decreased from $31 \%$ in the period $1995-1999$ to $23 \%$ in the last period (Table 2.1).

Older patients were less likely to receive chemotherapy and targeted treatment and more likely to receive hormonal treatment as first-line treatment (Table 2.2). In the period $2005-2008,20 \%$ of the patients $<50$ years received a targeted treatment, compared to $11 \%$ of the patients of $50-69$ years and $3 \%$ of those of 70 years or older $(P<0.0001)$. Older patients were also less likely to undergo surgery and to receive locoregional radiotherapy (Table 2.2). In the period $2005-2008,38 \%$ of the patients $<50$ years underwent surgery, compared to $24 \%$ of the patients of $50-69$ years and $15 \%$ of those of 70 years or older $(P<0.0001)$.

Table 2.2 Treatment characteristics of patients with primary metastatic breast cancer, according to age group $(n=8031)$.

\begin{tabular}{|c|c|c|c|c|c|c|c|c|}
\hline \multirow[t]{3}{*}{ Characteristic } & & \multicolumn{6}{|c|}{ Age at diagnosis (years) } & \multirow[b]{3}{*}{$P$} \\
\hline & & \multicolumn{2}{|c|}{$\begin{array}{c}<50 \\
(n=1706)\end{array}$} & \multicolumn{2}{|c|}{$\begin{array}{c}50-69 \\
(n=2991)\end{array}$} & \multicolumn{2}{|c|}{$\begin{array}{c}70+ \\
(n=3334)\end{array}$} & \\
\hline & & $\mathrm{n}$ & $(\%)$ & $\mathrm{n}$ & $(\%)$ & $\mathrm{n}$ & $(\%)$ & \\
\hline \multirow[t]{2}{*}{ Surgery } & Yes & 676 & (40) & 875 & (29) & 653 & (20) & $<0.0001$ \\
\hline & No & 1030 & (60) & 2116 & (71) & 2681 & $(80)$ & \\
\hline \multirow{2}{*}{ Radiotherapy } & Yes & 315 & (18) & 453 & (15) & 305 & (9) & $<0.0001$ \\
\hline & No & 1391 & (82) & 2238 & (85) & 3029 & (91) & \\
\hline \multirow{2}{*}{ Systemic treatment } & Yes & 1604 & (94) & 2660 & (89) & 2796 & (84) & $<0.0001$ \\
\hline & No & 102 & (6) & 331 & (11) & 538 & (16) & \\
\hline \multirow{2}{*}{ Chemotherapy } & Yes & 1169 & (69) & 1336 & (45) & 370 & (11) & $<0.0001$ \\
\hline & No & 537 & (31) & 1655 & (55) & 2964 & (89) & \\
\hline \multirow[t]{2}{*}{ Hormonal treatment } & Yes & 819 & (48) & 1746 & (58) & 2550 & (76) & $<0.0001$ \\
\hline & No & 887 & (52) & 1245 & (42) & 784 & (24) & \\
\hline \multirow[t]{2}{*}{ Targeted treatment* } & Yes & 104 & (20) & 109 & (11) & 32 & (3) & $<0.0001$ \\
\hline & No & 415 & (80) & 856 & (89) & 911 & (97) & \\
\hline
\end{tabular}

* Only available for patients diagnosed in the period 2005-2008

\section{Median survival}

The median survival was 1.42 years for patients diagnosed in the period 1995-1999, 1.61 years in the period 2000-2004 and 1.95 years in the period 2005-2008 (Table 2.3 and Figure 2.1). The difference between the periods 1995-1999 and 2000-2004 and between the periods 2000-2004 and 2005-2008 were both statistically significant ( $P=0.012$ and $P<0.0001$, respectively). When analyzed according to age group, the improvement of the median survival was most pronounced for patients of 50 years or 
younger between the periods 2000-2004 and 2005-2008 (Figure 2.2a and Table 2.3), with an increase of 2.44 to 3.60 years $(P<0.0001)$ and for patients aged $50-69$ years between the periods 1995-1999 and 2000-2004 (Figure 2.2b and Table 2.3), with an increase from 1.34 to 1.83 years $(P=0.009)$. The median survival in patients of 70 years and older did not differ significantly between the three periods (Figure $2.2 \mathrm{c}$ and Table 2.3). In the first period the median survival was 1.10 years, in the second 1.07 years and in the last period 1.25 years.

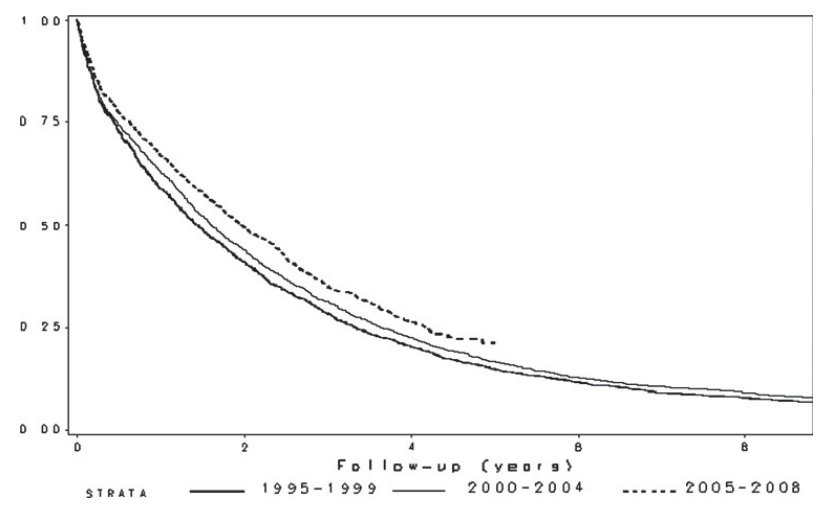

Figure 2.1 Overall survival of patients with primary metastatic breast cancer according to period of diagnosis.

Table 2.3 Median survival (yrs) and 95\% confidence intervals of patients with primary metastatic breast cancer, according to age group and period of diagnosis.

\begin{tabular}{lcccc}
\hline \multirow{2}{*}{ Age group } & \multicolumn{3}{c}{ Period of diagnosis } & \multirow{2}{*}{$P$} \\
\cline { 2 - 4 } & $1995-1999$ & $2000-2004$ & $2005-2008$ & \\
\hline$<50$ yrs & $2.29(2.09-2.74)$ & $2.44(2.12-2.78)$ & $3.60(2.88-4.14)$ & $<0.0001$ \\
$50-69$ yrs & $1.34(1.20-1.51)$ & $1.83(1.64-2.03)$ & $2.07(1.90-2.40)$ & $<0.0001$ \\
$70+$ yrs & $1.10(0.92-1.25)$ & $1.07(0.92-1.18)$ & $1.25(1.08-1.38)$ & 0.200 \\
All patients & $1.42(1.33-1.53)$ & $1.61(1.51-1.70)$ & $1.95(1.80-2.08)$ & $<0.0001$ \\
\hline
\end{tabular}

\section{Multivariable analysis}

In the multivariable analysis, taking into account the age of the patients, the size of the primary tumor and the use of systemic treatment, surgery and radiotherapy, the $H^{\prime}$ 's for mortality in the second and third period as compared to the first period were $0.95(P=0.08)$ and $0.83(P<0.0001)$, respectively (Table 2.4$)$. Older age and larger primary tumor size were associated with a higher mortality risk. Patients receiving systemic treatment (HR 0.34, 95\% Cl 0.32-0.37), loco-regional radiotherapy (HR 0.79, $95 \% \mathrm{Cl} 0.73-0.86$ ) or breast surgery (HR $0.64,95 \% \mathrm{Cl} 0.60-0.68$ ) had a significantly lower risk of death compared to the patients not receiving these treatments. The 
median survival of the patients undergoing surgery was 2.56 years, compared to 1.33 years for the patients without surgical treatment of the primary tumor (Figure 2.3).
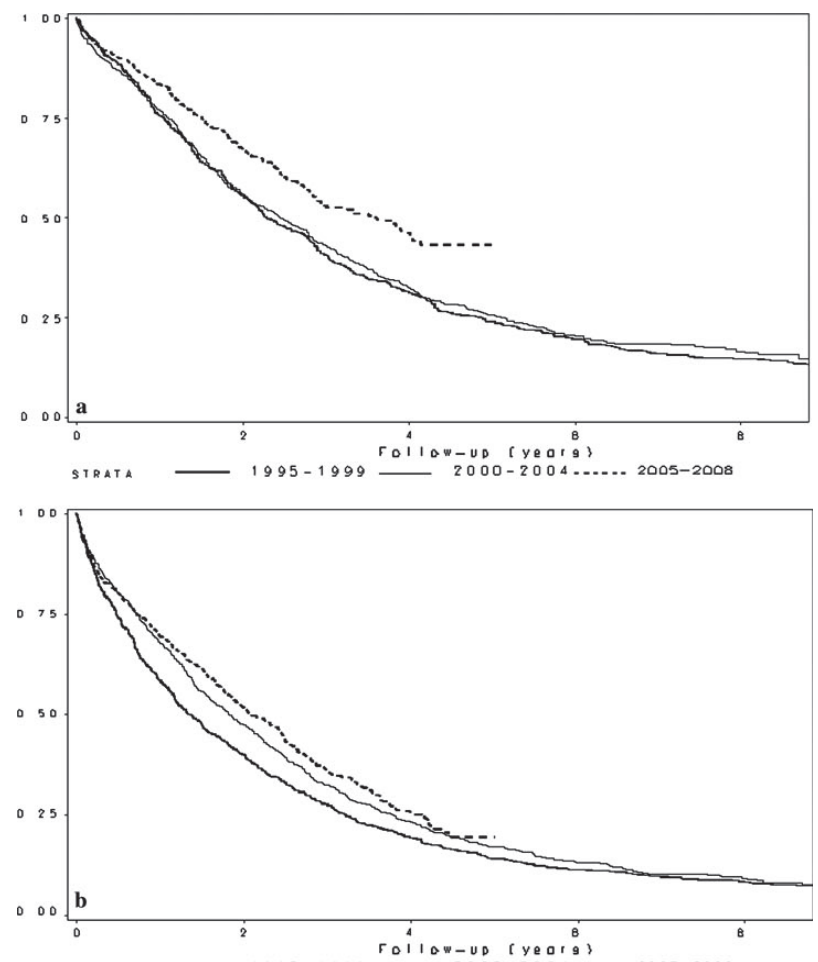

STRATA $1995-1999-2000-2004 \ldots \ldots$ 2005-2008

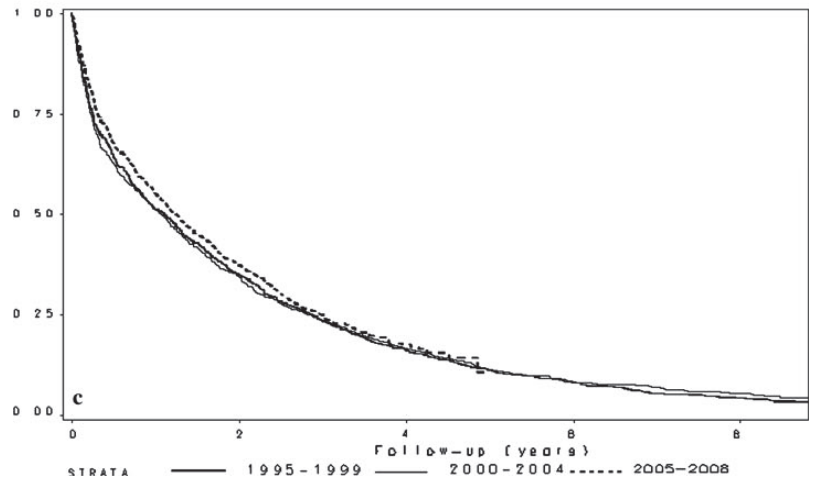

Figure 2.2 a Overall survival of patients with primary metastatic breast cancer aged younger than 50 years, according to period of diagnosis. b Overall survival of patients with primary metastatic breast cancer aged 50-69 years, according to period of diagnosis. c Overall survival of patients with primary metastatic breast cancer aged 70 years or older, according to period of diagnosis. 
Table 2.4 Multivariable analysis for time until death for patients with primary metastatic breast cancer $(n=7073)$ * $^{*}$

\begin{tabular}{llccc}
\hline Characteristic & & $\mathrm{HR}^{* *}$ & $(95 \% \mathrm{Cl})$ & $P$ \\
\hline Period of diagnosis & $1995-1999$ & 1 (Ref) & & \\
& $2000-2003$ & 0.95 & $(0.89-1.01)$ & 0.081 \\
Age at diagnosis (years) & $2004-2007$ & 0.83 & $(0.77-0.89)$ & $<0.0001$ \\
& $<50$ & 1 (Ref) & & \\
Tumor size & $50-69$ & 1.33 & $(1.24-1.44)$ & $<0.0001$ \\
& $70+$ & 1.59 & $(1.48-1.71)$ & $<0.0001$ \\
Surgery & T1-2 & 1 (Ref) & & \\
& T3-4 & 1.14 & $(1.08-1.20)$ & $<0.0001$ \\
Systemic treatment & No & 1 (Ref) & & \\
\multirow{2}{*}{ Radiotherapy } & Yes & 0.64 & $(0.60-0.68)$ & $<0.0001$ \\
& Yes & 1 (Ref) & & $<0.0001$ \\
& No & 0.34 & $(0.32-0.37)$ & $<0.0001$ \\
\hline
\end{tabular}

* 958 patients were not included in the multivariable because of missing information on tumor size. ${ }^{* *} \mathrm{HR}=$ Hazard Ratio

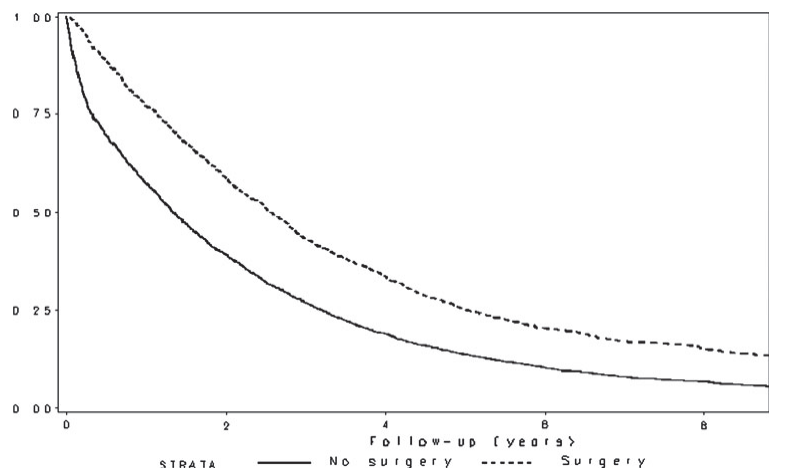

Figure 2.3 Overall survival of patients with primary distant metastatic breast cancer, according to surgical removal of the primary tumor.

A multivariable analysis according to age group, confirmed the increased prognosis of the patients treated in the period 2005-2008 (Table 2.5). The HR's for the patients treated in this period, as compared to those treated in the period 1994-1999 were $0.66(95 \% \mathrm{Cl} 0.55-0.79)$ for patients younger than 50 years, 0.81 (95\% Cl $0.72-0.91)$ for those of $50-69$ years old and 0.85 (95\% $\mathrm{Cl} 0.77-0.95)$ for patient of 70 years or older. In all age groups, the patients receiving systemic treatment, loco-regional radiotherapy or breast surgery had a significantly lower risk of death compared to the patients not receiving these treatments. 
24 Chapter 2

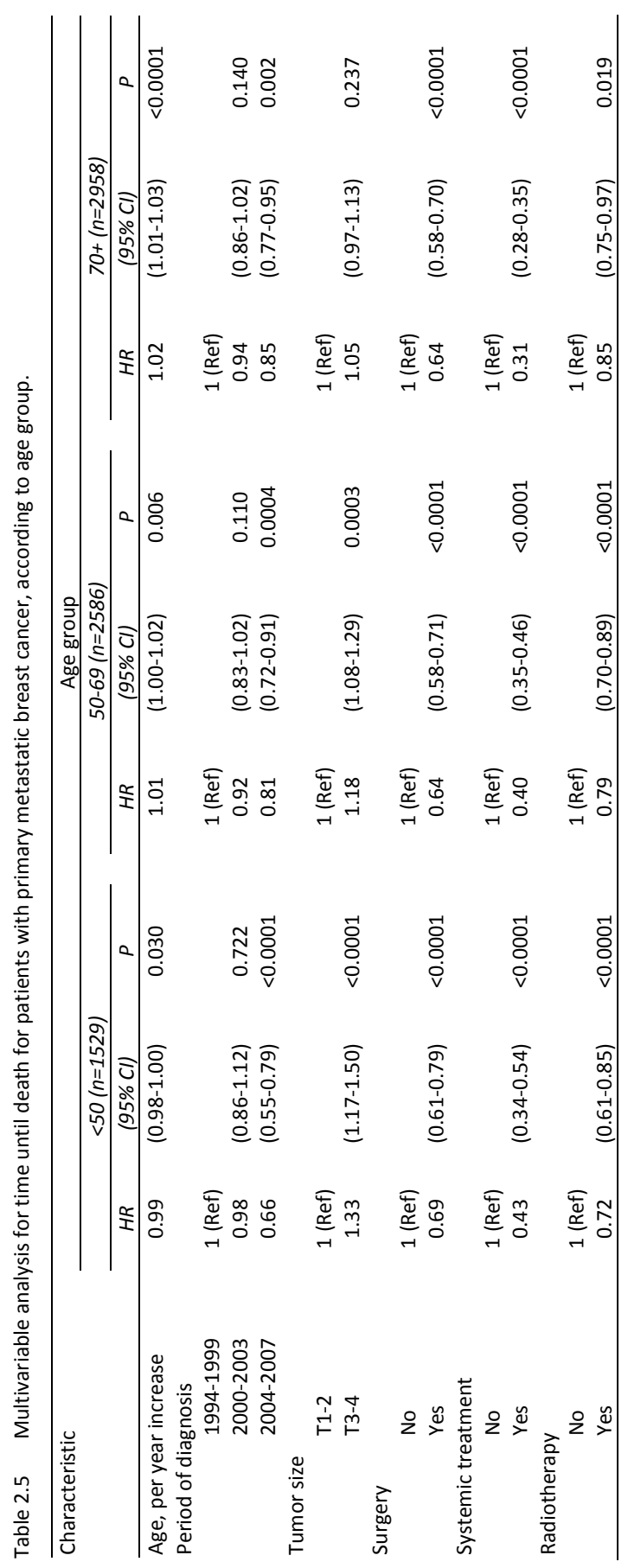




\section{Discussion}

According to the data of the Netherlands Cancer Registry, the median survival of patients with primary distant metastatic breast cancer has improved with 6 months in the period 1995-2008, now reaching almost 2 years. The improvement was most pronounced in the period 2000-2004 for patients aged 50-69 years and in the period 2005-2008 for the patients younger than 50 years. These improvements were also confirmed by the results of the multivariable analysis, adjusting for potential confounders.

Our nationwide study is one of the few large population-based studies on trends in prognosis of patients with primary metastatic breast cancer. Two other populationbased studies analyzed data from the Surveillance, Epidemiology, and End Results (SEER) program. ${ }^{9,12}$ The study by Dawood et al., involving 15,438 patients, showed an improvement of the median survival of 4 months between 1988 and $2003 .{ }^{12}$ In both studies, the increased prognosis of patients treated more recently was confirmed in a multivariable analysis. In a population-based study by Rapiti et al., based on 300 patients diagnosed between 1977 and 1996 and documented by the Geneva Cancer Registry, an improvement of the breast cancer-specific survival was demonstrated in the unadjusted but not in the adjusted multivariable analysis. ${ }^{7}$ In a previous population-based study, involving 1,089 patients treated in the southern part of the Netherlands, we observed an improvement of the median survival of 2.5 months for the patients treated in the period 1995-2002 as compared to those treated in the period 1975-1984. ${ }^{4}$

Most studies on trends in prognosis of patients with primary metastatic breast cancer are hospital-based, ${ }^{13}$ or also included patients with secondary metastatic disease or patients participating in randomized clinical trials comparing different lines of chemotherapy. ${ }^{14-17}$ The interval between the primary tumor and the diagnosis of metastatic disease is an important prognostic factor. Therefore, including patients with secondary metastatic disease might introduce bias when differences in the metastasis-free interval exist between patients treated in different time-periods. Inclusion of patients treated in trials could also lead to biased results as they tend to have a better prognosis than patients receiving the same treatment outside trials, probably because of the strict in- and exclusion criteria applied to trial populations. ${ }^{18,19}$ Similar to our study, a hospital-based study by Andre et al., including 724 patients, also showed an improvement in the median survival of 6 months; being diagnosed between 1994 and 2000 was associated with a 37\% lower risk of mortality in comparison to patients diagnosed between 1987 to $1993 .^{13}$ None of the studies described above covered a patient group treated after 2003. Our study, which contains data of patients treated until 2009, is the first to evaluate the possible impact in daily practice of the treatments that have been introduced mainly since that time, such as trastuzumab. 
Patients with primary metastatic disease are thought to have more aggressive disease than patients with metastases diagnosed during follow-up after treatment of primary breast cancer, and therefore their prognosis might be poorer. On the other hand, use of chemotherapy and endocrine treatment in the adjuvant setting may induce drug resistance and leave fewer options for optimal systemic treatment when metastases occur. A large population-based study from Canada by Chia et al. on 2,150 patients with metastatic breast cancer, of whom only $21 \%$ had primary metastatic disease, showed that the median survival improved from 1.2 years for patients diagnosed in the period 1991-1992 to 1.6 years for those diagnosed in the period 1999-2001. ${ }^{15}$ These figures suggest that there is not a large difference in the survival between patients with primary and secondary metastatic breast cancer.

The proportion of patients with stage IV breast cancer receiving first-line systemic treatment did not change during the study period. Therefore, the introduction of more effective drugs is the most likely explanation for the better prognosis of patients treated after 1999. The fact that the benefit was larger for patients younger than 50 years is supported by the more frequent use of targeted treatment among this age group in the period of $2005-2008$, when $20 \%$ received targeted therapy as first-line treatment, compared to $11 \%$ of the patients between 50 and 70 years old and only $3 \%$ of those older than 70 years.

Patients of 70 years and older had a poor prognosis, which improved only slightly during the study period. This may be explained by the fact that chemotherapy and targeted treatment were less frequently used in the elderly. Elderly patients were also less likely to undergo surgery or receive loco-regional radiotherapy. Other studies, with respect to the prognosis of elderly patients, show a significantly higher mortality risk in older patients with metastatic disease. ${ }^{7,9,11}$ Comorbidity and frailty are more common among older patients and limit the therapeutic choices. ${ }^{20}$ This may be an important explanation for the fact that the prognosis in elderly women with metastatic breast cancer has improved much less than in women younger than 70 years.

In our study, surgical treatment of the primary tumor was associated with lower mortality in all age groups. During the study period, the proportion of patients treated with surgery decreased. In a previously published review of the literature we found a pooled hazard ratio of $0.65(95 \% \mathrm{Cl}, 0.59-0.72)$ in favour of surgical treatment of the breast tumor, ${ }^{21}$ which is almost equal to the HR calculated in the current study. One of the explanations for the effect of surgery is that removing the tumor will lower the tumor load and reduce the amount of circulating tumor cells in the blood, which is known to be an independent predictor of overall survival in patients with metastatic breast cancer. ${ }^{22}$ Nevertheless, the observational nature of our study does not allow us to draw strong conclusions about the causality of the association between surgery and survival. Loco-regional radiotherapy also appeared to be associated with a significant improvement of the median survival. A similar association was found in a study by Le 
Scodan et al., in which radiotherapy was an independent prognostic factor in multivariate analysis, with a hazard ratio of $0.70(95 \% \mathrm{Cl}, 0.58$ to 0.85$){ }^{23}$

Our population-based study is based on information from more than 8,000 patients with primary distant metastatic breast cancer, gathered by the Netherlands Cancer Registry and including virtually all patients with stage IV breast cancer in the Netherlands. Information of patients diagnosed until 2009 was available, with followup until 2010, which allowed us to provide up-to-date results. Unfortunately, only first-line treatment was recorded and no data were available on the specific drugs used. This is clearly a limitation of a retrospective analysis based on cancer registry data. This may also explain why the sum of first-line hormonal therapy and chemotherapy is larger than $100 \%$, that is, for some patients more than one treatment modality may have been recorded, perhaps in those who had an early switch because of non-responsiveness to the first initiated treatment. Obviously, also other biases may have occurred, for instance by patient selection for specific therapies like radiotherapy or surgery.

Twelve percent of the patients in our study did not receive systemic treatment. Some underreporting cannot be ruled out. However, in two other studies on prognosis of primary metastatic breast cancer by Blanchard et al. and Kahn et al. similar percentages, of $8 \%$ and $22 \%$ respectively, were reported. ${ }^{5,10}$ Apparently, a substantial part of these patients present with very advanced, rapidly progressive disease for which systemic treatment is no viable option anymore.

Information on the use of targeted treatment was only available since 2005, as was also the case for the site of distant metastatic involvement. However, it is not very likely that these sites and the number of metastatic sites have changed much during the three time periods. Our study is covering a relatively short period, which makes it less likely that changes in radiologic facilities (except perhaps for the introduction of positron emission tomography) have had a large impact on the detection of metastatic disease. Moreover, the percentage of patients with metastatic disease has remained rather stable during the different time periods, also indicating that screening methods and indications for peri-operative screening for patients without clinical signs of metastases have not changed between 1995 and 2008. An increase in the amount of patients participating in the breast cancer screening program may have caused the increase in the proportion of patients with T1 and T2 tumors. However, in the multivariable analysis adjustments have been made for this shift in tumor size.

In conclusion, an overall improvement of 6 months is observed between 1995 and 2008 in the median survival of patients with primary distant metastatic breast cancer, resulting in a median survival of almost 2 years for the patients treated in the last period. This improvement was most pronounced in patients younger than 50 years. The increased efficacy of chemotherapy and the introduction of targeted treatments are the most likely explanation. Surgical removal of the primary breast tumor and loco-regional radiotherapy do also seem to have a positive impact on survival, but to be able to rule out selection bias, it would require a randomized study to quantify the 
added value of loco-regional treatment and tumor control to systemic therapy in the management of patients with stage IV breast cancer. 


\section{References}

1. Coebergh JW, Janssen-Heijnen ML, Louwman WJ, et al. Cancer incidence, care and survival in the South of the Netherlands, 1955-1999: a report of the Eindhoven cancer registry with cross-border implications. Eindhoven: Comprehensive Cancer Centre South (IKZ); 2001:29

2. Ries LA, Harkins D, Krapch M et al. SEER cancer statistics review. Bethesda, MD: National Cancer Institute; 1975-2003 http://seer.cancer.gov/csr/1975_2003

3. Mauri D, Polyzos NP, Salanti G, Pavlidis N, loannidis JPA. Multiple-treatments meta-analysis of chemotherapy and targeted therapies in advanced breast cancer. J Natl Cancer Inst. 2008;100:17801791

4. Ernst MF, van de Poll-Franse LV, Roukema JA, Coebergh JW, van Gestel CM, Vreugdenhil G, Louwman MJ, Voogd AC. Trends in the prognosis of patients with primary metastatic breast cancer diagnosed between 1975 and 2002. Breast. 2007;16:344-351

5. Khan SA, Stewart AK, Morrow M. Does aggressive local therapy improve survival in metastatic breast cancer? Surgery. 2002;132:620-627

6. Babiera GV, Rao R, Feng L, Meric-Bernstam F, Kuerer HM, Singletary SE, Hunt KK, Ross MI, Gwyn KM, Feig BW, Ames FC, Hortobagyi GN. Effect of primary tumor extirpation in breast cancer patients who present with stage IV disease and an intact primary tumor. Ann Surg Oncol. 2006;13:776-782

7. Rapiti E, Verkooijen HM, Vlastos G, Fioretta G, Neyroud-Caspar I, Sappino AP, Chappuis PO, Bouchardy C. Complete excision of primary breast tumor improves survival of patients with metastatic breast cancer at diagnosis. J Clin Oncol. 2006;24:2743-2749

8. Fields RC, Jeffe DB, Trinkaus K, Zhang Q, Arthur C, Aft R, Dietz JR, Eberlein TJ, Gillanders WE, Margenthaler JA. Surgical resection of the primary tumor is associated with increased long-term survival in patients with stage IV breast cancer after controlling for site of metastasis. Ann Surg Oncol. 2007;14:3345-3351

9. Gnerlich J, Jeffe DB, Deshpande AD, Beers C, Zander C, Margenthaler JA. Surgical removal of the primary tumor increases overall survival in patients with metastatic breast cancer. Analysis of the 1988-2003 SEER data. Ann Surg Oncol. 2007;14:2187-2194

10. Blanchard DK, Shetty PB, Hilsenbeck SG, Elledge RM. Association of surgery with improved survival in stage IV breast cancer patients. Ann Surg. 2008;247:732-738

11. Ruiterkamp J, Ernst MF, van de Poll-Franse LV, Bosscha K, Tjan-Heijnen VC, Voogd AC. Surgical resection of the primary tumour is associated with improved survival in patients with distant metastatic breast cancer at diagnosis. Eur J Surg Oncol. 2009;35:1146-1151

12. Dawood S, Broglio K, Gonzalez-Angulo AM, Buzdar AU, Hortobagyi GN, Giordano SH. Trends in survival over the past to decades among white and black patients with newly diagnoses stage IV breast cancer. J Clin Oncol. 2008;26:4891-4898

13. Andre F, Slimane K, Bachelot T, Dunant A, Namer M, Barrelier A, Kabbaj O, Spano JP, Marsiglia H, Rouzier R, Delaloge S, Spielmann M. Breast cancer with synchronous metastases: trends in survival during a 14-year period. J Clin Oncol. 2004;22:3302-3308

14. Dafni U, Grimani I, Zyrafas A, Eleftheraki AG, Fountzilas G. Fifteen-year trends in metastatic breast cancer survival in Greece. Breast Cancer Res Treat. 2010;119:621-631

15. Chia SK, Speers CH, D'yachkova Y, Kang A, Malfair-Taylor S, Barnett J, Coldman A, Gelmon KA, O'reilly $\mathrm{SE}$, Olivotto IA. The impact of new chemotherapeutic and hormone agents on survival in a populationbased cohort of women with metastatic breast cancer. Cancer. 2007;110:973-979

16. Gennari A, Conte P, Rosso R, Orlandini C, Bruzzi P. Survival of metastatic breast carcinoma patients over a 20-year period. Cancer. 2005;104:1742-1750

17. Largillier R, Ferrero JM, Doyen J, Barriere J, Namer M, Mari V, Courdi A, Hannoun-Levi JM, Ettore F, Birtwisle-Peyrottes I, Balu-Maestro C, Marcy PY, Raoust I, Lallement M, Chamorey E. Prognostic factors in 1038 women with metastatic breast cancer. Ann Oncol. 2008;19:2012-2019

18. Bijker N, Peterse JL, Fentiman IS, Julien JP, Hart AA, Avril A, Cataliotti L, Rutgers EJ. Effects of patient selection on the applicability of results from a randomised clinical trial (EORTC 10853) investigating breast-conserving therapy for DCIS. Br J Cancer. 2002;87:615-620 
19. [no authors listed] Results of chemotherapy for unselected patients with acute myeloblastic leukaemia: effect of exclusions on interpretation of results. The Toronto Leukemia Study Group. Lancet. 1986;1:786-788

20. Louwman WJ, Janssen-Heijnen ML, Houterman S, Voogd AC, van der Sangen MJ, Nieuwenhuijzen GA, Coebergh JW. Less extensive treatment and inferior prognosis for breast cancer patients with comorbidity: a population-based study. Eur J Cancer. 2005;41:779-785

21. Ruiterkamp J, Voogd AC, Bosscha K, Tjan-Heijnen VCG, Ernst MF. Impact of breast surgery on survival in patients with distant metastases at initial presentation. A systematic review of the literature. Breast Cancer Res Treat. 2010;120:9-16

22. Cristofanilli M, Budd GT, Ellis MJ, Stopeck A, Matera J, Miller MC, Reuben JM, Doyle GV, Allard WJ, Terstappen LW, Hayes DF. Circulating tumor cells, disease progression, and survival in metastatic breast cancer. N Engl J Med. 2004;351:781-791

23. Le Scodan R, Stevens D, Brian E, Floiras JL, Cohen-Solal C, De La Lande B. Breast cancer with synchronoius metastases: survival impact of exclusive localregional radiotherapy. J Clin Oncol. 2009;27:1375-1381 


\title{
CHAPTER 3
}

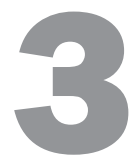

SURGICAL RESECTION OF THE PRIMARY TUMOR IS ASSOCIATED WITH IMPROVED SURVIVAL IN PATIENTS WITH DISTANT METASTATIC BREAST CANCER AT DIAGNOSIS

\author{
J Ruiterkamp \\ MF Ernst \\ LV van de Poll-Franse \\ K Bosscha \\ VCG Tjan-Heijnen \\ AC Voogd
}




\section{Abstract}

\section{Objective}

Recent studies indicate that removal of the primary tumor may have a beneficial effect on mortality risk of patients with primary distant metastatic breast cancer (stage IV), although most of them did not rule out confounding by the presence of comorbidity. In this retrospective study the impact of surgical resection of the primary tumor on the survival of patients with primary distant metastatic disease is investigated, taking into account the presence of comorbidity and other potential confounders.

\section{Methods}

Between 1993 and 2004, 15769 patients with breast cancer were diagnosed in the South of the Netherlands. This study included the patients with distant metastatic disease at initial presentation, which was $5 \%$ of all patients. Of them, $40 \%$ had surgery of the primary tumor. Follow-up was completed until 1 July 2006.

\section{Results}

Median survival of the patients who had surgery of their primary tumor was significantly longer than for the patients who did not have surgery (31 vs. 14 months). The 5-year survival rates were $24.5 \%$ and $13.1 \%$, respectively $(P<0.0001)$. In a multivariable Cox regression analysis, adjusting for age, period of diagnosis, T-classification, number of metastatic sites, comorbidity, use of loco-regional radiotherapy and use of systemic therapy, surgery appeared to be an independent prognostic factor for overall survival ( $\mathrm{HR}=0.62 ; 95 \% \mathrm{Cl} 0.51-0.76)$.

\section{Conclusions}

Removal of the primary tumor in patients with primary distant metastatic disease was associated with a reduction of the mortality risk of around $40 \%$. The association was independent of age, presence of comorbidity and other potential confounders, but a randomized controlled trial will be needed to rule out residual confounding. 


\section{Introduction}

Distant metastatic breast cancer is considered to be an incurable disease and therefore is only treated with palliative intent. Local treatment is recommended only if the primary tumor is symptomatic. In contrast to the current treatment strategy, recent studies indicate that (complete) resection of the primary tumor significantly may prolong survival of patients with primary distant metastatic breast cancer. ${ }^{1-6}$ Most of these studies did not rule out confounding of their findings by the presence of comorbidity. Patients with comorbidity may be less likely to undergo surgery, which might explain part of the difference in prognosis between patients with and without surgery. In this retrospective study the impact of surgical resection of the primary tumor on the survival of patients with primary distant metastatic breast cancer is investigated, taking into account the presence of comorbidity and other potential confounders.

\section{Patients and methods}

\section{Patients}

The Eindhoven Cancer Registry (ECR) of the Comprehensive Cancer Centre South records data on all patients newly diagnosed with cancer in the South of the Netherlands. The region covered by the ECR comprises 2.3 million inhabitants and 16 general hospitals, but no academic centre. Ten hospitals and the 2 radiotherapy institutes participate in the ECR. In these hospitals 15769 patients were diagnosed with breast cancer in the period 1993-2004. This study included the 728 patients with distant metastatic disease at initial presentation (4.6\%). Data were collected by the ECR from copies of the pathology reports and the medical records. Primary treatment (as planned within 6 months of diagnosis) was recorded, including surgery, locoregional radiotherapy, chemotherapy (with or without targeted therapy) or hormonal therapy, as well as details on the surgical procedure, such as breast-conserving surgery, mastectomy and axillary dissection. The patients were staged according to the TNM system of the UICC. ${ }^{7}$ For patients who did not undergo surgery and/or for whom the postoperative tumor size was unknown, we used the clinical tumor size as measured on the mammogram or at palpation, to determine the T-classification. Information on the dominant localization of metastatic disease and the number of metastatic sites was also recorded. Noted different sites were bone, liver, lung/pleurae, brain, skin and unknown/not specified sites. Also a separation was made between patients with only non-visceral metastases and patients with visceral metastases. 


\section{Comorbidity}

Since 1993, the registry also records comorbidity according to a slight adaptation of the list of serious diseases drawn up by Charlson and colleagues. ${ }^{8}$ In short, the following important conditions were recorded: chronic obstructive pulmonary diseases (COPD), cardiovascular and cerebrovascular diseases, other malignancies (excluding basal cell carcinoma of the skin), and diabetes mellitus. Connective tissue diseases, rheumatoid arthritis, kidney, bowel, and liver diseases, dementia, tuberculosis and other chronic infections were also recorded. ${ }^{9}$

\section{Follow-up}

Follow-up was completed until 1 July 2006. This information was obtained from the municipal registries in the area of the ECR and the Central Bureau for Genealogy. The latter is an institution that collects data on all deceased Dutch citizens via the municipal registries. In this way, information on patients who had moved outside the registry area was also obtained. Patients who died outside the Netherlands were wrongly considered as 'being alive'. However, the estimated proportion of these patients is less then $0.3 \%$.

\section{Statistical analyses}

Survival time was defined as the period between the date of diagnosis and the date of death or 1 July 2006 for the patients who were still alive. Crude survival rates were calculated using the life-table method. The log-rank test was performed to evaluate significant differences between survival curves of surgically and non-surgically treated patients in univariate analyses. Stratified analyses were performed to compare surgically and non-surgically treated patients in subgroups defined by age $(<50,50-69$ or 70+ years), T-classification (T1-2 or T3-4), number of metastatic sites (1 or $>1$ ), presence of visceral metastases (yes or no) and comorbidity (present or absent). To examine the independent contribution of surgery of the primary tumor, a multivariable Cox regression analysis was performed, including the following variables: age, period of diagnosis, T-classification, number of metastatic sites, presence of visceral metastases, comorbidity, use of loco-regional radiotherapy and use of systemic therapy.

Information on clinical and postoperative axillary nodal status was missing for more than $30 \%$ of the patients and was therefore not included in the univariate and multivariable analysis.

Hazard ratios (HR) with 95\% confidence intervals $(\mathrm{Cl})$ and $P$ values were estimated with respect to the reference category for each co-variate.

The SAS computer package (version 9.1) was used for all statistical analyses (SAS Institute Inc., Cary, NC, USA, 1999). 


\section{Results}

\section{Patient, tumor, and treatment characteristics}

Of the 728 patients diagnosed with primary metastatic breast cancer, diagnosed in the period 1993-2004, 288 had surgery of the primary tumor. Patient, tumor and treatment characteristics for surgically and non-surgically treated patients are listed in Table 3.1. The patients who had surgery of the primary tumor were younger than the patients whose primary tumor remained in situ. They were also less likely to have metastatic involvement of multiple sites or visceral metastases and had smaller primary tumors. Patients who had surgery were also less likely to have concomitant diseases; $54 \%$ of the surgically treated patients had no comorbidity versus $37 \%$ in the non-surgically treated patients, and the proportion of patients with 2 or more concomitant diseases was smaller ( $11 \%$ vs. $19 \%)$. The use of loco-regional radiotherapy was higher among the patients who had surgery (34\% vs. $10 \%$ ) as was the use of systemic therapy ( $89 \%$ vs. $79 \%$ ). The proportion of patients who had surgery decreased from $55 \%$ in the period $1993-1996$, to $39 \%$ in the period $1997-2000$ and to $30 \%$ in the period 2001-2004 $(P<0.0001)$.

Of the 288 patients who received surgery, 85 had breast-conserving surgery and 189 mastectomy. Type of surgery could not be retrieved for 14 patients. Axillary dissection was performed in 190 patients, of whom 44 had breast-conserving surgery and 146 mastectomy.

\section{Univariate analyses}

Median survival of the patients who had surgery of their primary tumor was significantly longer than for the patients who did not have surgery (31 vs. 14 months) and the 5-year survival rates were $24.5 \%$ (95\% Cl 18.9-30.1) and $13.1 \%$ (95\% Cl 9.516.7), respectively (Figure 3.1). A stratified analysis according to age, tumor size, number of metastatic sites, and localization of metastases (non-visceral or visceral) and presence of concomitant diseases showed that surgery was strongly associated with a prolonged survival in all strata $(P<0.01)$. A somewhat weaker, but still statistically significant, association was found for patients with more than one metastatic site, where the median survival was 16 months for the patients with surgery, compared to 10 months for the patients without surgery $(P=0.02)$.

For the patients who had surgery, no significant difference in overall survival was observed between those with breast-conserving surgery or mastectomy $(P=0.80)$. Patients undergoing axillary dissection tended to have a better overall survival than those without axillary dissection, but this difference was restricted to the first year after treatment. 
Table 3.1 Comparison of characteristics of surgically versus non-surgically treated patients with distant metastatic breast cancer at diagnosis $(n=728)$.

\begin{tabular}{|c|c|c|c|c|c|}
\hline & \multicolumn{4}{|c|}{ Surgical removal of primary tumour } & \multirow[b]{3}{*}{$P$} \\
\hline & \multicolumn{2}{|c|}{ Yes $(n=288)$} & \multicolumn{2}{|c|}{ No $(n=440)$} & \\
\hline & $\mathrm{n}$ & (\%) & $\mathrm{n}$ & (\%) & \\
\hline Age (years) & & & & & 0.003 \\
\hline$<50$ & 74 & (26) & 81 & (18) & \\
\hline $50-69$ & 126 & (44) & 172 & (39) & \\
\hline $70+$ & 88 & (31) & 187 & (43) & \\
\hline Mean (range) & 60.2 & $(24-92)$ & 64.8 & $(28-93)$ & \\
\hline Period of diagnosis & & & & & $<0.0001$ \\
\hline 1993-1996 & 109 & (38) & 89 & (20) & \\
\hline $1997-2000$ & 92 & (32) & 145 & (33) & \\
\hline 2001-2004 & 87 & (30) & 206 & (47) & \\
\hline T classification & & & & & $<0.0001$ \\
\hline $\mathrm{T} 1$ & 61 & (21) & 56 & (13) & \\
\hline $\mathrm{T} 2$ & 112 & (39) & 106 & (24) & \\
\hline T3 & 20 & (7) & 32 & (7) & \\
\hline $\mathrm{T} 4$ & 91 & (32) & 188 & (43) & \\
\hline Missing & 4 & (1) & 58 & (13) & \\
\hline More than 1 distant metastatic site* & & & & & $<0.0001$ \\
\hline No & 213 & (74) & 249 & (57) & \\
\hline Yes & 60 & (21) & 164 & (37) & \\
\hline Missing & 15 & (5) & 27 & (6) & \\
\hline Visceral metastases* & & & & & 0.09 \\
\hline No & 120 & (42) & 148 & (34) & \\
\hline Yes & 153 & (53) & 265 & (60) & \\
\hline Missing & 15 & (5) & 27 & (6) & \\
\hline Number of concomitant diseases & & & & & $<0.0001$ \\
\hline 0 & 155 & (54) & 163 & (37) & \\
\hline 1 & 72 & (25) & 140 & (32) & \\
\hline$\geq 2$ & 32 & (11) & 82 & (19) & \\
\hline Missing & 29 & (10) & 55 & (13) & \\
\hline Loco-regional radiotherapy & & & & & $<0.0001$ \\
\hline No & 190 & (66) & 396 & (90) & \\
\hline Yes & 98 & (34) & 44 & (10) & \\
\hline Systemic treatment & & & & & 0.0003 \\
\hline No & 32 & (11) & 94 & (21) & \\
\hline Yes & 256 & (89) & 346 & (79) & \\
\hline
\end{tabular}

* situation at the time of first presentation 


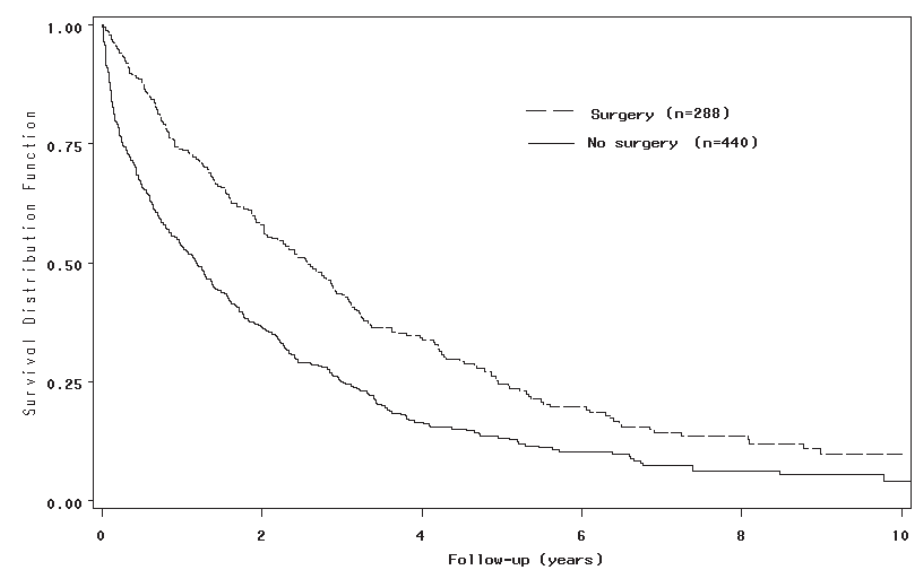

Figure 3.1 Relative survival of patients with primary distant metastatic breast cancer, according to surgical removal of the primary tumor $(P<0.0001)$.

\section{Multivariable analyses}

The results of the multivariable Cox regression analysis are listed in Table 3.2. Due to missing values for one or more of the co-variates, 174 of the 728 patients could not be included in the multivariable model. Surgery appeared to be an independent prognostic factor associated with overall survival ( $\mathrm{HR}=0.62 ; 95 \% \mathrm{Cl} 0.51-0.76)$. Other independent prognostic factors, besides surgery, were the number of metastatic sites, use of systemic treatment and age, with patients with one metastatic site and with systemic treatment having a better survival, and older age being associated with worse survival. The presence of concomitant diseases was associated with a worse survival, but this association was not statistically significant $(P=0.06)$. Prognosis did not improve over time. No statistically significant interaction was found between surgery and any of the co-variates included in the multivariable model.

To reduce the number of missing values, a separate multivariable model was run, not including concomitant diseases as a co-variate. This model included 626 patients, but did not substantially alter the risk estimates for the other co-variates, and surgery was still associated with a significantly reduced risk of death ( $\mathrm{HR}=0.66 ; 95 \% \mathrm{Cl} 0.55-0.80)$. Finally, a separate multivariable analysis for the patients undergoing surgery, adjusting for the same factors as demonstrated in Table 3.2, did not demonstrate a significant association between the type of surgery (i.e., breast-conserving surgery versus ablation) or use of axillary dissection on overall survival $(P=0.59$ and $P=0.35$, respectively). 
Table 3.2 Multivariable Cox' regression analysis predicting overall survival in patients with distant metastatic breast cancer at diagnosis $(n=554)$.

\begin{tabular}{|c|c|c|c|c|}
\hline Characteristic & & $\mathrm{HR}$ & $(95 \% \mathrm{Cl})$ & $P$ \\
\hline \multirow[t]{2}{*}{ Surgery } & No & 1 (Ref) & & \\
\hline & Yes & 0.62 & $(0.51-0.76)$ & $<0.0001$ \\
\hline \multirow[t]{3}{*}{ Age at diagnosis } & $<50$ & 1 (Ref) & & \\
\hline & $50-69$ & 1.32 & $(1.02-1.70)$ & 0.03 \\
\hline & $70+$ & 1.71 & $(1.23-2.11)$ & 0.0005 \\
\hline \multirow[t]{3}{*}{ Period of diagnosis } & 1993-1996 & 1 (Ref) & & \\
\hline & $1997-2000$ & 0.91 & $(0.72-1.14)$ & 0.41 \\
\hline & 2001-2004 & 1.00 & $(0.77-1.28)$ & 0.98 \\
\hline \multirow[t]{2}{*}{ Tumour classification } & T1-T2 & 1 (Ref) & & \\
\hline & T3-T4 & 1.07 & $(0.89-1.30)$ & 0.47 \\
\hline \multirow[t]{2}{*}{ More than one distant metastatic site* } & No & 1 (Ref) & & \\
\hline & Yes & 1.58 & $(1.24-2.01)$ & 0.0002 \\
\hline \multirow[t]{2}{*}{ Visceral metastases } & No & 1 (Ref) & & \\
\hline & Yes & 1.13 & $(0.90-1.42)$ & 0.30 \\
\hline \multirow[t]{2}{*}{ Concomitant disease(s) } & No & 1 (Ref) & & \\
\hline & Yes & 1.21 & $(1.00-1.48)$ & 0.06 \\
\hline \multirow[t]{2}{*}{ Radiotherapy } & No & 1 (Ref) & & \\
\hline & Yes & 1.00 & $(0.79-1.27)$ & 0.98 \\
\hline \multirow[t]{2}{*}{ Systemic therapy } & No & 1 (Ref) & & \\
\hline & Yes & 0.45 & $(0.34-0.58)$ & $<0.0001$ \\
\hline
\end{tabular}

$\mathrm{HR}=$ hazard ratio $95 \% \mathrm{Cl}=95 \%$ confidence interval. * situation at the time of first presentation

\section{Discussion}

Our results demonstrate that patients with primary distant metastatic breast cancer who underwent surgical removal of the primary tumor had a median survival that was 16 months longer than for patients who did not undergo surgery. This result is difficult to interpret, as the patients with surgery were younger, had smaller tumors, were less likely to have comorbidity, more than one metastatic site or visceral metastases and were more often treated in combination with loco-regional radiotherapy and/or systemic treatment. However, the impact of surgical resection of the tumor persisted in a multivariable analysis adjusting for these potential confounders, with a hazard ratio of 0.62 and a $95 \%$ confidence interval ranging from 0.51 to 0.76 . Among the surgically treated patients, no difference in overall survival was observed between those who underwent lumpectomy or mastectomy. In our study, the proportion of patients with primary distant metastatic breast cancer undergoing surgery decreased from $55 \%$ in the period $1993-1996$ to $30 \%$ in the period 2001-2004. At the same time, no improvement was observed in the prognosis of these patients, despite the introduction of more effective drugs, such as trastuzumab, taxanes and aromatase inhibitors. A careful conclusion might be that the life-prolonging effects of these new drugs have been counterbalanced by the decrease in the use of surgery. 


\section{Type of surgery and surgical margins}

All studies conducted to analyze the impact of local surgical therapy in women presenting with stage IV disease and an intact primary tumor show that surgical resection of the tumor is associated with a better prognosis ${ }^{1-6}$. Hazard ratios for mortality vary from 0.53 to 0.63 and are thus comparable with the result from our study. However, some studies taking into account surgical resection margins, indicated that the improved survival remained limited to or was larger for those patients whose primary breast lesion had been removed with free surgical margins. ${ }^{1,3}$ In our study, no information on margin status was available. It could be argued that clear margins were more likely to be obtained in patients who underwent mastectomy. Thus, type of surgery could be interpreted as a proxy for margin status, but no difference in overall survival could be observed between patients who underwent lumpectomy or mastectomy. Axillary dissection also did not appear to have an additional benefit, which is in line with the study by Khan et al., which also took into account this factor, as well as the number of involved axillary nodes. ${ }^{1}$

\section{Comorbidity and performance status}

Our study is the second, in which an attempt was made to control for bias due to an unequal distribution of comorbidity among the patients with and without surgery. $A$ direct comparison with the results from the study by Field and colleagues is hampered by the lack of information on the results of the multivariable analysis in their study. ${ }^{11}$ Adjusting for presence of comorbidity and age at the same time had little additional effect on the risk estimates, when compared to adjusting for age alone. As was illustrated by the hazard ratios in Table 3.2, the association of overall survival with comorbidity was much weaker than with age. It could be that comorbidity is not a very accurate descriptor of the general condition of a patient. Measures of general performance, such as the WHO-scale or the Karnofsky score may be more suitable for that, but will also not be sufficient to rule out the risk of residual confounding by other factors.

\section{Timing of surgery and systemic treatment}

No information on timing of surgery was available for our study. Distant metastases could have been found directly following surgery with curative intent, after the metastatic work-up was completed, or could already have been identified at the time of surgery, with the primary aim of surgery being loco-regional tumor control. The first group is probably small, as it was generally accepted and recommended in the treatment guidelines that there is no need for peri-operative screening for metastases in patients with a pre-operative diagnosis of early stage breast cancer without clinical signs of distant tumor spread, unless the post-operative tumor stage appears to be poorer than anticipated. Chest X-ray, bone scanning and liver ultrasound were 
generally recommended for patients with tumors larger than $5 \mathrm{~cm}$ (i.e. T3), tumors with direct extension to the chest wall or skin (i.e. T4a-d) and/or patients with evidence of extensive regional disease at clinical examination.

Information was also lacking on the timing of systemic treatment in the patients who underwent surgery. In a recent study by Cady et al., it is suggested that most of the survival advantage for patients undergoing surgery is explained by case selection bias, meaning that patients with a good response to initial systemic therapy also more likely to undergo surgery than those with a poor response. ${ }^{10}$

Review of the individual charts of the patients would be indicated, to analyse if such biases are also likely to have taken place in our study.

\section{Biological rationale behind the findings}

One possible explanation for the beneficial effect of surgery is that lowering the tumor load will reduce the number of circulating tumor cells in the blood, which are an important source of new metastatic deposits. Number of circulating tumor cells is known to be an independent predictor of progression-free survival and overall survival in patients with metastatic breast cancer. ${ }^{11}$ In that view, the removal of the primary tumor should be considered as part of a multimodal strategy to prevent dissemination of tumor cells, also including radiotherapy and systemic treatment. Other positive effects of removal of the primary tumor have also been postulated, such as the restoration of the immune system and improvement of the nutritional status of the patient.

\section{Conclusions}

In summary, our results are in line with previous studies and provide additional evidence that surgical removal of the primary tumor is associated with a significantly longer survival time in patients with distant metastatic breast cancer at diagnosis. The main limitation of our study, which it has in common with all other retrospective studies on this subject, is that surgery has not been assigned by randomisation. Even the adjustment for the presence of concurrent diseases at the time of diagnosis, as was done in our study, does not rule out residual confounding by other, unrecorded prognostic factors. ${ }^{12}$ The only way to overcome this problem is to perform a welldesigned prospective study. More specific questions of such a trial are the optimal sequencing of systemic treatment and surgery and the prognostic value of the response the primary tumor to systemic treatment, with or without surgery. Finally, translational research, assessing the role of circulating tumor cells, should also be integrated, to understand the tumor biological mechanism underlying a potentially beneficial effect of surgical excision of the primary tumor in women with stage IV breast cancer. 


\section{References}

1. Khan SA, Stewart AK, Morrow M. Does aggressive local therapy improve survival in metastatic breast cancer? Surgery. 2002;132:620-626

2. Gnerlich J, Jeffe DB, Deshpande AD, Beers C, Zander C, Margenthaler JA. Surgical removal of the primary tumor increases overall survival in patients with metastatic breast cancer: analysis of the 1988-2003 SEER data. Ann Surg Oncol. 2007;14:2187-2194

3. Rapiti E, Verkooijen HM, Vlastos G, Fioretta G, Neyroud-Caspar I, Sappino AP, Chappuis PO, Bouchardy C. Complete excision of primary breast tumor improves survival of patients with metastatic breast cancer at diagnosis. J Clin Oncol. 2006;24:2743-2749

4. Fields RC, Jeffe DB, Trinkaus K, Zhang Q, Arthur C, Aft R, Dietz JR, Eberlein TJ, Gillanders WE, Margenthaler JA. Surgical resection of the primary tumor is associated with increased long-term survival in patients with stage IV breast cancer after controlling for site of metastasis. Ann Surg Oncol. 2007; 14:3345-3351

5. Babiera GV, Rao R, Feng L, Meric-Bernstam F, Kuerer HM, Singletary SE, Hunt KK, Ross MI, Gwyn KM, Feig BW, Ames FC, Hortobagyi GN. Effect of primary tumor extirpation in breast cancer patients who present with stage IV disease and an intact primary tumor. Ann Surg Oncol. 2006;13:776-782

6. Blanchard DK, Shetty PB, Hilsenbeck SG, Elledge RM. Association of surgery with improved survival in stage IV breast cancer patients. Ann Surg. 2008;247:732-738

7. Hermanek P, Sobin LH, editors. UICC TNM classification of malignant tumours. Berlin: Springer-Verlag. 1987:94-99

8. Charlson ME, Pompei P, Ales KL, MacKenzie CR. A new method of classifying prognostic comorbidity in longitudinal studies: development and validation. J Chronic Dis. 1987;40:373-383

9. Coebergh JW, Janssen-Heijnen ML, Post PN, Razenberg PP. Serious co-morbidity among unselected cancer patients newly diagnosed in the southeastern part of The Netherlands in 1993-1996. J Clin Epidemiol. 1999;52:1131-1136

10. Cady B, Nathan NR, Michaelson JS, Golshan M, Smith BL. Matched pair analyses of stage IV breast cancer with or without resection of primary breast site. Ann Surg Oncol. 2008;15:3384-3395

11. Cristofanilli M, Budd GT, Ellis MJ, Stopeck A, Matera J, Miller MC, Reuben JM, Doyle GV, Allard WJ, Terstappen LW, Hayes DF. Circulating tumor cells, disease progression, and survival in metastatic breast cancer. N Engl J Med. 2004;351:781-791

12. Khan SA. Primary tumor resection in stage IV breast cancer: consistent benefit, or consistent bias? Ann Surg Oncol. 2007;14:3285-3287 


\title{
CHAPTER 4
}

PRESENCE OF SYMPTOMS AND TIMING OF SURGERY DO NOT AFFECT THE PROGNOSIS OF PATIENTS WITH PRIMARY METASTATIC BREAST CANCER

\author{
J Ruiterkamp \\ AC Voogd \\ K Bosscha \\ JA Roukema \\ GAP Nieuwenhuijzen \\ VCG Tjan-Heijnen \\ MF Ernst
}




\section{Abstract}

\section{Objective}

Though most studies on surgical resection of the breast tumor in patients with primary distant metastatic breast cancer (MBC) indicated that surgery is associated with prolonged overall survival, some state that this effect has been confounded by indication and timing of surgery. In this study we analysed these possible confounders and their relation to overall survival.

\section{Methods}

To determine the impact of potential confounders, individual charts of 279 patients with primary $\mathrm{MBC}$ were reviewed.

\section{Results}

The median survival in patients treated with surgery of the breast tumor was 39 months, compared to 15 months for those without surgery $(P<0.0001)$. The median survival of patients with symptomatic metastatic disease $(n=112)$ was 19 months, compared to 22 months for those without symptomatic disease ( $n=167)(P=0.15)$. Patients who received surgery and whose metastases were detected before surgery of the breast tumor had taken place $(n=40)$ had a median survival of 38 months, compared to 40 months for patients in whom the metastatic disease was diagnosed after surgery $(n=43)(P=0.81)$.

\section{Conclusion}

Presence of symptomatic metastatic disease was no significant prognostic factor for patients with distant metastasis at diagnosis, neither was the timing of surgery. It is unlikely that the prolonged survival after surgery is explained by these potentials confounders. 


\section{Introduction}

In recent years, several studies have been published on the effect of surgical resection of the primary tumor in breast cancer patients with distant metastatic disease at initial presentation. Most of these studies indicate that surgery of the primary tumor is associated with prolonged overall survival in these patients. ${ }^{1-7}$

The decision to perform surgery of the primary tumor depends on many factors, such as age, tumor size, the number of metastatic sites, co-morbidity and performance status. Although the analyses were adjusted for these potential confounders, bias could not be ruled out completely because of the retrospective designs of all studies. Other researchers have investigated additional confounding factors and they concluded that the survival benefit, seen in patients who were treated with a surgical resection of the primary tumor, was not as strong as reported previously or could be fully explained by these additional confounders. ${ }^{8-10}$ For instance, in one of these studies the authors concluded that the benefit of surgery is confined to patients operated upon before diagnosis of metastatic disease, as there was no survival advantage in patients who received an operation of the breast tumor after the diagnosis of the metastatic disease had taken place. ${ }^{9}$

So far, most studies have been performed with data from population-based or hospital-based cancer registries, which lack information on the timing of surgery or other potential confounders and which might suffer from missing values or coding errors.

Earlier we reported on 728 patients with distant metastatic breast cancer at diagnosis in the south of the Netherlands in the period 1993-2004, using data from the population-based Eindhoven Cancer Registry. A improved survival was demonstrated in patients treated with breast surgery. ${ }^{6}$ We questioned if the aforementioned biases could be identified in our study and whether these might explain part of the positive effect of breast surgery. To answer this question we meticulously reviewed the individual charts of 279 patients with primary distant metastatic breast cancer. Among others, we recorded information on presence of symptoms of metastatic disease and timing of surgery (before or after diagnosis of metastatic disease). Furthermore, in some studies the effect of surgery on overall survival was smaller or even absent in patients with positive surgical margins. ${ }^{1,3}$ To confirm these findings we also collected information on surgical margins for those patients who underwent surgical resection of the primary tumor. 


\section{Patients and methods}

\section{Patients}

The Eindhoven Cancer Registry (ECR) of the Comprehensive Cancer Centre South records data on all newly diagnosed patients with cancer in the south of the Netherlands. With these data we already performed a study on 728 patients with primary distant metastatic breast cancer. ${ }^{6}$ The current study includes a selection of the patients, derived from four large teaching hospitals in the south of the Netherlands, resulting in 318 eligible patients diagnosed between 1995 and 2005 for whom extensive analysis was possible.

\section{Definitions}

Primary metastatic breast cancer was defined as diagnosis of distant metastases before or within one month after the diagnosis of the breast tumor. Presence or absence of symptomatic metastatic disease was recorded. Symptomatic metastases were defined as metastases causing complains before the primary tumor was diagnosed and therefore were the first sign of disease. Timing of surgery of the primary tumor related to timing of diagnoses of the metastases was defined as (1) surgery before diagnosis of the metastases (all within 60 days of diagnosis of the primary tumor); (2) surgery after diagnosis of the metastases; (3) delayed surgery in order to gain local control (in symptomatic local disease). The third group consisted of four patients, they were included and analyzed in the non surgical group.

\section{Data collection and follow-up}

Details on surgical procedure, such as margin status, were noted. Type of systemic treatment was documented including hormonal treatment and chemotherapy. Radiotherapy was divided in loco-regional radiotherapy and radiotherapy in case of painful bone metastases or cerebral metastases. Based on the chart review 39 patients were excluded: 22 patients were excluded because they did not have primary distant metastatic disease according to our definition, 15 because they did not have breast cancer, but another primary tumor and 2 because they did not have metastatic disease. Thus 279 patients were eligible for analysis. Follow-up was completed until the 1st of January 2010. Data were collected by the ECR from the pathology reports and medical records. We collected information (JR) on age at diagnosis, TNM classification, receptor status, symptoms of metastases and specific information on site and number of metastases. Noted different sites were bone, liver, lung/pleurae, cutaneous, central nervous system and other sites. 


\section{Statistical analysis}

The aim of this study was to analyze the effect of surgery on overall survival with respect to presence of symptomatic metastases, timing of surgery and margin status after surgery.

Survival time was defined as the period between the date of diagnosis of the primary tumor and the date of death or 1 January 2010 for the patients who were still alive. Crude survival rates were calculated using the life-table method. Characteristics of patients with symptomatic and asymptomatic metastatic disease were compared with respect to age, T-classification, receptor status, site of metastases, number of metastatic sites, symptomatic metastatic disease and margin status by using Chisquare test or Fisher's Exact test for class variables and t-test for continuous variables. The same tests were used to compare the characteristics of patients treated with surgery versus those without surgery and of patients who had surgery before and after the diagnosis of metastatic disease. The log-rank test and Kaplan-Meier analyses were performed to compare the survival rates.

The SAS computer software package (version 9.1) was used for all statistical analyses (SAS Institute Inc., Cary, NC, USA, 1999).

\section{Results}

Of the 279 patients with primary metastatic breast cancer, 84 underwent surgery of the breast tumor as part of their treatment. Patients who underwent surgery were somewhat younger (60 vs. 62 yrs), but this difference was not statistically significant. Patients undergoing surgery were more likely to have a tumor with a positive progesterone receptor status and less likely to have metastases at more than one site (9 vs. $45 \%$ ) compared to patients who did not receive surgery. They were also less likely to have lung or pleural metastases (10 vs. $30 \%$ ). No other significant differences were observed between both groups with respect to the site of metastatic disease.

\section{General characteristics according to symptomatic or non-symptomatic metastases}

Of the 279 patients with primary metastatic breast cancer 112 had symptomatic disease, related to their metastases (Table 4.1). Those patients were somewhat older than the patients without metastatic symptoms (median survival 65 vs. 60 years), but this was not statistically significant. No significant differences were observed between both groups with respect to tumor size (49 vs. 45\% T1-2), the expression of oestrogen and progesterone receptors and Her2neu expression. Patients presenting with symptomatic metastatic disease were more likely to have cutaneous metastases (13 vs. $4 \%, P=0.002$ ) and metastases of the central nervous system ( 4 vs. $1 \%, P=0.03$ ). 
Table 4.1 General characteristics of patients with symptomatic and with asymptomatic primary metastatic breast cancer $(n=279)$.

\begin{tabular}{|c|c|c|c|}
\hline & $\begin{array}{c}\text { Symptomatic } \\
(n=112) \\
n\end{array}$ & $\begin{array}{c}\text { Asymptomatic } \\
(n=167) \\
n\end{array}$ & $P$ \\
\hline Age at diagnosis (years) & & & 0.74 \\
\hline$<50$ & 24 & 40 & \\
\hline $50-69$ & 49 & 76 & \\
\hline$\geq 70$ & 39 & 51 & \\
\hline Median age [range] & $65.0[27.1-89.1]$ & $60.3[29.4-93.6]$ & \\
\hline T-classification & & & 0.46 \\
\hline $\mathrm{T} 1$ & 24 & 28 & \\
\hline $\mathrm{T} 2$ & 31 & 47 & \\
\hline T3 & 6 & 14 & \\
\hline $\mathrm{T} 4$ & 32 & 58 & \\
\hline Unknown & 19 & 20 & \\
\hline \multicolumn{4}{|l|}{ Oestrogen receptor status } \\
\hline ER positive & 81 & 115 & 0.50 \\
\hline ER negative & 20 & 39 & \\
\hline ER other/unknown & 11 & 13 & \\
\hline \multicolumn{4}{|l|}{ Progesterone receptor status } \\
\hline PR positive & 62 & 88 & 0.67 \\
\hline PR negative & 39 & 66 & \\
\hline PR other/unknown & 11 & 13 & \\
\hline Her2neu & & & 0.53 \\
\hline Overexpression & 5 & 13 & \\
\hline No overexpression & 36 & 50 & \\
\hline Unknown & 71 & 104 & \\
\hline \multicolumn{4}{|l|}{ Site of metastases } \\
\hline Bone & 75 & 104 & 0.42 \\
\hline Liver & 34 & 52 & 0.89 \\
\hline Lung/pleural & 29 & 38 & 0.55 \\
\hline Cutaneous & 15 & 6 & 0.002 \\
\hline CNS & 5 & 1 & 0.03 \\
\hline Other/unknown & 15 & 18 & 0.51 \\
\hline Number of metastatic sites & & & 0.006 \\
\hline 1 & 62 & 112 & \\
\hline 2 & 31 & 39 & \\
\hline$\geq 3$ & 18 & 9 & \\
\hline Unknown & 1 & 7 & \\
\hline \multicolumn{4}{|l|}{ Treatment } \\
\hline Surgery & 18 & 66 & $<0.0001$ \\
\hline Hormonal therapy & 86 & 124 & 0.63 \\
\hline Chemotherapy & 51 & 100 & 0.02 \\
\hline Radiotherapy, loco-regional & 9 & 35 & 0.004 \\
\hline Radiotherapy, bone & 52 & 56 & 0.03 \\
\hline Radiotherapy, cns & 7 & 9 & 0.76 \\
\hline
\end{tabular}

No other differences were observed between both groups with respect to the site of metastatic disease. The number of metastatic sites differed significantly; in patients with symptomatic disease $16 \%$ had three or more metastatic sites, compared to $5 \%$ in patients without symptomatic disease $(P=0.006)$. Regarding surgery only $16 \%$ of the patients with symptomatic metastases had an operation of the breast tumor, compared with $40 \%$ of the patients without symptomatic disease $(P<0.0001)$. Patients with symptomatic metastases were less often treated with chemotherapy (46 vs. $60 \%$, 
$P=0.02$ ) and with locoregional radiotherapy (8 vs. $21 \%, P=0.004$ ). They were more likely to be treated with radiotherapy for bone metastases (46 vs. $34 \%, P=0.03$ ). Treatment with hormonal therapy was comparable between the two groups.

\section{General characteristics according to timing of surgery}

Of the 84 patients whose primary tumor was removed surgically, 43 underwent surgery before metastatic disease was diagnosed and 40 after the diagnosis of metastatic disease. For one patient the timing of the surgical treatment was not known.

Of the 40 patients who had surgery after diagnosis of metastatic disease, the interval between the diagnosis of primary tumor and the date of surgery varied between 0 and 61 months, with a mean interval of 5 months. Eighteen patients received surgery within 2 months after the diagnosis of the primary tumor, in nine patients surgery was performed after good response of the tumor to systemic treatment and in the remaining thirteen patients information on the motivation for surgery was not available.

Patients who underwent surgery of the primary tumor before metastatic disease was diagnosed had significantly smaller tumors (74 vs. 33\% T1-2), were less likely to have hormone receptor positive tumors (70 vs. $95 \%$ ER and/or PR positive) and tended to be more likely to have liver metastases, were less likely to have bone metastases (56 vs. $75 \%$ ) and less likely to have symptomatic metastases at diagnosis (5 vs. 40\%) (Table 4.2).

\section{Survival}

The median survival in patients treated with surgery of the breast tumor was 39 months, compared to 15 months for those without surgery $(P<0.0001)$ (Figure 4.1). The median survival of patients with symptomatic metastases ( $n=112)$ was 19 months, compared to 22 months for those without symptomatic disease $(n=167) \quad(P=0.15)$ (Figure 4.2). Patients who underwent surgery of the breast tumor and whose metastases were detected before surgery $(n=40)$ had a median survival of 38 months, compared to 40 months for the patients with metastatic disease diagnosed after surgery $(n=43)(P=0.81)$ (Figure 4.3$)$.

\section{Margin status}

Of the patients who underwent surgery, 61 had a complete resection of the primary tumor and 15 were reported by the pathologist to have tumor-positive resection margins. For 11 patients information on margin status was not available. The median survival of patients with a complete resection was 41 months, compared to 28 months for those with tumor-positive margins $(P=0.06)$. 
Table 4.2 Characteristics of patients who had surgery before or after the diagnosis of the metastases $(n=83)$.

\begin{tabular}{|c|c|c|c|}
\hline & \multirow{2}{*}{\multicolumn{2}{|c|}{ Surgery before $(n=43) \quad$ Surgery after $(n=40)$}} & \multirow[t]{3}{*}{$P$} \\
\hline & & & \\
\hline & $\mathrm{n}$ & $\mathrm{n}$ & \\
\hline Age at diagnosis (years) & & & 0.53 \\
\hline$<50$ & 15 & 10 & \\
\hline $50-69$ & 17 & 16 & \\
\hline$\geq 70$ & 11 & 14 & \\
\hline Median age [range] & $54.6[32.6-88.7]$ & $64.8[27.1-92.1]$ & \\
\hline T-classification & & & 0.0001 \\
\hline T1-2 & 32 & 13 & \\
\hline T3-4 & 5 & 21 & \\
\hline Unknown & 6 & 6 & \\
\hline Hormone receptor status & & & 0.01 \\
\hline ER and/or PR positive & 30 & 38 & \\
\hline ER and PR negative & 11 & 2 & \\
\hline ER/PR unknown & 2 & 0 & \\
\hline \multicolumn{4}{|l|}{ Site of metastases } \\
\hline Bone & 24 & 30 & 0.07 \\
\hline Liver & 14 & 6 & 0.06 \\
\hline Lung/pleural & 3 & 5 & 0.39 \\
\hline Cutaneous & 2 & 1 & 0.30 \\
\hline CNS & 0 & 1 & 0.60 \\
\hline Other/unknown & 3 & 3 & 0.93 \\
\hline Number of metastatic sites & & & 0.52 \\
\hline 1 & 39 & 35 & \\
\hline$\geq 2$ & 3 & 5 & \\
\hline Unknown & 1 & 0 & \\
\hline Symptomatic metastases & & & $<0.0001$ \\
\hline Yes & 2 & 16 & \\
\hline No & 41 & 24 & \\
\hline Margin status & & & 0.86 \\
\hline Complete resection & 33 & 28 & \\
\hline Positive margins & 7 & 8 & \\
\hline Unknown & 3 & 4 & \\
\hline
\end{tabular}

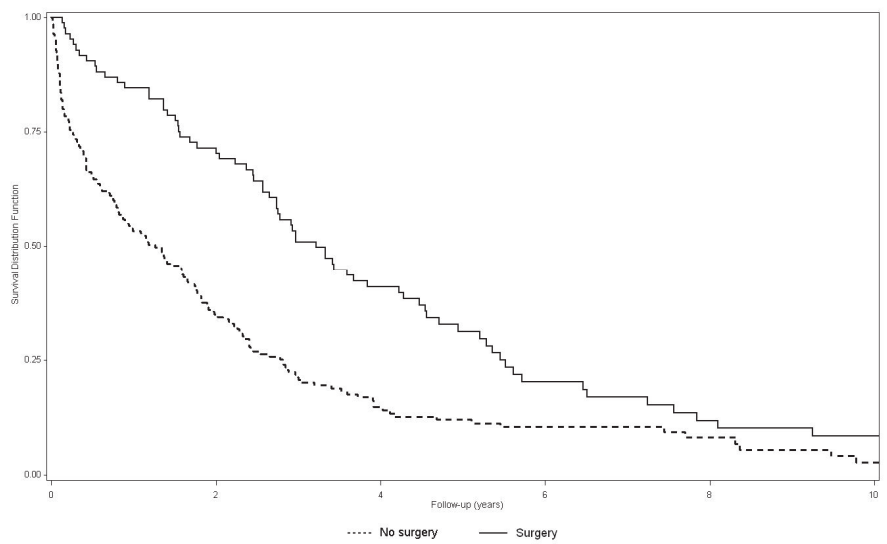

Figure 4.1 Survival according to surgery. 


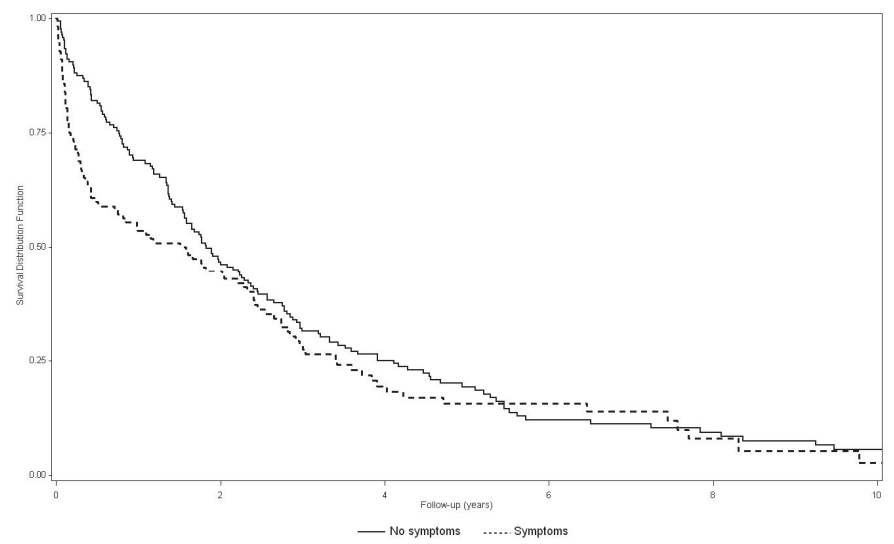

Figure 4.2 Survival according to symptoms of metastatic disease.

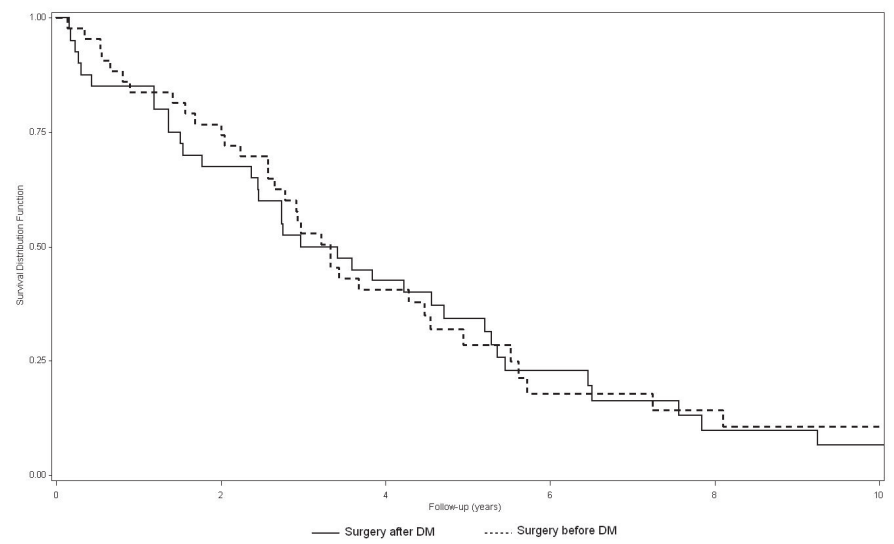

Figure 4.3 Survival according to detection of metastases (DM) before or after surgery.

\section{Discussion}

In the present study, based on detailed chart review, we showed a similar benefit of breast surgery on overall survival as has been reported in previous studies in patients with primary metastatic breast cancer. ${ }^{1-7}$ Also, the presence of symptomatic metastatic disease and timing of surgery were very unlikely to be important confounders of this association. Finally, the median survival of patients treated with a complete resection of the breast tumor tended to be better than of patients who had tumor-positive margins. 


\section{Patient differences}

In line with our current observations, other studies showed that patients who were selected for surgery of the primary tumor were significantly younger, ${ }^{2-6,8,10-13}$ had smaller tumors, ${ }^{3-7,11}$ were less likely to have metastases at more than one site, ${ }^{1-3,5-7,9}$ and were less likely to have visceral metastases, ${ }^{1-3,5,6,9,11,13}$ compared to patients who were not treated with surgery of the breast tumor. Information from our detailed chart review also indicated that patients who were treated with surgery, were less likely to have symptomatic metastases and less likely to have lung or pleural metastases.

\section{Symptomatic metastases}

Our study is the first one examining the differences between patients with and without symptomatic primary metastatic breast cancer. Patients with symptomatic metastases were more likely to have three or more metastatic sites and less likely to receive surgery of the breast tumor as part of their treatment. These differences are in line with what one would expect regarding the presentation and clinical management of patients with symptomatic metastases.

\section{Timing of surgery}

A distinction was made between patients whose metastases were detected before and after surgery of the primary tumor. It appeared that half of the patients were diagnosed with metastases after surgery. Our results showed no significant difference in median survival between both groups. This is an interesting finding, because the patients who underwent surgery before the diagnosis of metastatic disease had smaller tumors and were less likely to have hormone receptor positive tumors, compared with patients who had surgery after metastatic disease was diagnosed. One would expect that this first patient group would have a better prognosis, but the median survival between both groups was comparable. A possible explanation is that the first group had more aggressive tumors with a higher metastatic potential, which had a negative influence on their survival, compared to those who had surgery after diagnosis of the metastases. It should be noted, however, that patient numbers in the subgroups were relatively small, thus decreasing the power to detect clinically relevant differences. Three other studies compared patients who were diagnosed with metastasis preoperatively to those diagnosed postoperatively and also found no significant differences between these two subgroups in overall survival. ${ }^{7,9,12}$

\section{Resection margins}

We observed that patients who had a complete resection of the tumor tended to have a better survival than patients with positive tumor margins. These results are in 
agreement with other studies. ${ }^{1,3,14}$ Only one study did not report a survival advantage for patients treated with a complete resection of the primary tumor. ${ }^{7}$ The association between margin status and survival in patients with primary distant metastatic breast cancer seems to indicate that tumors with positive margins have a more aggressive behaviour or that the primary tumor is in some way controlling the growth of the metastatic sites. Other investigators have found a significant relationship between margin involvement in patients with localized breast cancer and the risk of subsequent distant disease, which indicates that margin involvement in some way may be a marker of the aggressiveness of the tumor. ${ }^{15}$ Further research, for example on circulating tumor or endothelial cells in blood and the immune response and angiogenic potential of metastases, should be performed in order to provide an answer to the question which mechanism is causing the survival benefit in the patients with tumor-free surgical margins of the primary tumor.

\section{Data collection}

This study contains detailed information from clinical charts, compared to many other studies relying on databases of cancer registries without information on the timing of surgery and margin status. The charts also revealed some coding errors and missing information in the original database, provided by the cancer registry. This indicates that studies based on existing databases may benefit from chart review to complete missing information and check the quality of the data.

\section{Conclusions}

There were several differences between the patients who had surgery before or after the diagnosis of the metastases. Patients who had their operation before the diagnosis of the metastases had smaller tumors, were less likely to have hormone positive tumors, were less likely to have bone metastases and were less likely to have symptomatic metastases at diagnosis. Still, there was no significant difference in median survival between both groups. This leads to the conclusion that both timing of surgery and detection method of metastases are no important confounders. A future randomized controlled trial (RCT) that investigates the effect of surgery of the breast tumor in patients with primary metastatic breast cancer should include a protocol for (pre-operative) screening for metastases and pre-stratification for important confounders, such as age, dominant location of distant metastases, hormonal receptor status and HER2Neu status. Currently, studies are running in India (RCT, ongoing, not recruiting), Turkey (RCT, recruiting at the moment, no results published), United States (observational study, recruiting at the moment) and Austria (RCT, ongoing). ${ }^{16}$ In the Netherlands we will start a RCT on this very interesting subject Autumn 2011. 


\section{References}

1. Khan SA, Stewart AK, Morrow M. Does aggressive local therapy improve survival in metastatic breast cancer? Surgery. 2002;132:620-627

2. Babiera GV, Rao R, Feng L, Meric-Bernstam F, Kuerer HM, Singletary SE, Hunt KK, Ross MI, Gwyn KM, Feig BW, Ames FC, Hortobagyi GN. Effect of primary tumor extirpation in breast cancer patients who present with stage IV disease and an intact primary tumor. Ann Surg Oncol. 2006;13:776-782

3. Rapiti E, Verkooijen HM, Vlastos G, Fioretta G, Neyroud-Caspar I, Sappino AP, Chappuis PO, Bouchardy C. Complete excision of primary breast tumor improves survival of patients with metastatic breast cancer at diagnosis. J Clin Oncol. 2006;24:2743-2749

4. Gnerlich J, Jeffe DB, Deshpande AD, Beers C, Zander C, Margenthaler JA. Surgical removal of the primary tumor increases overall survival in patients with metastatic breast cancer. Analysis of the 1988-2003 SEER data. Ann Surg Oncol. 2007;14:2187-2194

5. Blanchard DK, Shetty PB, Hilsenbeck SG, Elledge RM. Association of surgery with improved survival in stage IV breast cancer patients. Ann Surg. 2008;247:732-738

6. Ruiterkamp J, Ernst MF, van de Poll-Franse LV, Bosscha K, Tjan-Heijnen VC, Voogd AC. Surgical resection of the primary tumor is associated with improved survival in patients with distant metastatic breast cancer at diagnosis. Eur J Surg Oncol. 2009;35:1146-1151

7. Neuman HB, Morrogh M, Gonen M, Van Zee KJ, Morrow M, King TA. Stage IV breast cancer in the era of targeted therapy. Does surgery of the primary tumor matter? Cancer. 2010;116:1226-1233

8. Cady B, Nathan NR, Michaelson JS, Golshan M, Smith BL. Matched pair analyses of stage IV breast cancer with or without resection of primary breast site. Ann Surg Oncol. 2008; 15:3384-3395

9. Bafford AC, Burstein HJ, Barkley CR, Smith BL, Lipsitz S, Iglehart JD, Winer EP, Golshan M. Breast surgery in stage IV breast cancer: impact of staging and patient selection on overall survival. Breast Cancer Res Treat. 2009;115:7-12

10. Leung AM, Vu HN, Nguyen KA, Thacker LR, Bear HD Effects of surgical excision on survival of patients with stage IV breast cancer. J Surg Res. 2010;161:83-88

11. Fields RC, Jeffe DB, Trinkaus K, Zhang Q, Arthur C, Aft R, Dietz JR, Eberlein TJ, Gillanders WE, Margenthaler JA. Surgical resection of the primary tumor is associated with increased long-term survival in patients with stage IV breast cancer after controlling for site of metastasis. Ann Surg Oncol. 2007; 14:3345-3351

12. Hazard HW, Gorla SR, Scholtens D, Kiel K, Gradishar WJ, Khan SA. Surgical resection of the primary tumor, chest wall control, and survival in women with metastatic breast cancer. Cancer. 2008;113:8;2011-2019

13. Shien $T$, Kinoshita T, Shimizu C, Hojo T, Taira N, Doihara H, Akashi-Tanaka S. Primary tumor resection improves the survival of younger patients with metastatic breast cancer. Oncol Rep. 2009;21:827-832

14. Rao R, Feng L, Kuerer HM, Singletary SE, Bedrosian I, Hunt KK, Ross MI, Hortobagyi GN, Feig BW, Ames FC, Babiera GV. Timing of surgical intervention for the intact primary in stage IV breast cancer patients. Ann Surg Oncol. 2008;15:1696-1702

15. Voogd AC, Nielsen M, Peterse JL, Blichert-Toft M, Bartelink H, Overgaard $M$, van Tienhoven $G$, Andersen KW, Sylvester RJ, van Dongen JA; Danish Breast Cancer Cooperative Group. Breast Cancer Cooperative Group of the European Organization for Research and Treatment of Cancer. Differences in risk factors for local and distant recurrence after breast-conserving therapy or mastectomy stage I and II breast cancer: pooled results of two large European randomized trials. J Clin Oncol. 2001;19:1688-1697

16. http://clinicaltrials.gov 


\section{CHAPTER 5}

IMPACT OF BREAST SURGERY ON SURVIVAL IN PATIENTS WITH DISTANT METASTASES AT INITIAL PRESENTATION

A systematic review of the literature

J Ruiterkamp AC Voogd

$\mathrm{K}$ Bosscha

VCG Tjan-Heijnen

MF Ernst 


\section{Abstract}

\section{Objective}

According to current treatment standards, patients with metastatic breast cancer at diagnosis receive palliative therapy. Local treatment of the breast is only recommended if the primary tumor is symptomatic. Recent studies suggest that surgical removal of the primary tumor has a favorable impact on the prognosis of patients with primary metastatic breast cancer. We performed a systematic review of the literature to weigh the evidence for and against breast surgery in this patient group.

\section{Methods}

Ten retrospective studies were found in which the use of breast surgery in primary metastatic breast cancer and its impact on survival was examined. The hazard ratios of the studies were pooled to provide an estimate of the overall effect of surgery, and the results and conclusions of the studies were analyzed.

\section{Results}

A crude analysis, without adjustment for potential confounders, showed that surgical removal of the breast lesion in stage IV disease was associated with a significantly higher overall survival rate in seven of the ten studies, and a trend towards a better survival in the three remaining studies. Surgery of the primary tumor appeared to be an independent factor for an improved survival in the multivariate analyses from the individual studies, with hazard ratios ranging from 0.47 to 0.71 . The pooled hazard ratio for overall mortality was $0.65(95 \% \mathrm{Cl} 0.59-0.72)$ in favor of the patients undergoing surgery.

\section{Conclusions}

This systematic review of the literature suggests that surgery of the primary breast tumor in patients with stage IV disease at initial presentation does have a positive impact on survival. In order to provide a definite answer on whether local tumor control in patients with primary metastatic disease improves survival, a randomized controlled trial comparing systemic therapy with and without breast surgery is needed. 


\section{Introduction}

About $11 \%$ of all women in the western world will develop breast cancer. Of all breast cancer patients $3-10 \%$ have distant metastases at initial presentation. ${ }^{1}$ Median survival of these patients is in the range of 16 to 24 months and is determined by several factors, including number and site of metastatic lesions, and tumor characteristics like hormone receptor and HER2neu status. ${ }^{2,3}$ During the last decades, the treatment of metastatic breast cancer has undergone considerable changes, with taxanes and third-generation aromatase-inhibitors being introduced in the nineties of the previous century and, among others, trastuzumab and bevacizumab in the current decade. $^{4-6}$

Until now, we continue to adhere to the concept that metastatic breast cancer is an incurable disease. In line with this concept, aggressive local therapy is thought to provide no survival advantage, and the primary goals of local treatment are the prevention or palliation of symptoms. Therefore, local treatment of the primary tumor is only recommended if the primary tumor is symptomatic. However, recent studies suggest that breast surgery has a favorable impact on the prognosis of patients with primary metastatic breast cancer, and that it may be time to reconsider the treatment paradigm "no surgery of the primary tumor"..$^{7-13}$ On the other hand, not all studies addressing this subject have reported a better prognosis for the patients undergoing surgery ${ }^{14-16}$, and the investigators of these studies suggest that the beneficial effect seen in other studies may be the result of selection bias.

In this review of the literature we try to weigh the evidence for and against breast surgery in patients with primary metastatic breast cancer. We also explored the literature to look for possible biological mechanisms explaining the findings from clinical studies. We conclude with an overall summary of our review and with a final recommendation on further research on this topic.

\section{Methods}

A search was performed in PubMed in May 2009. The following search strategy was used: breast cancer AND (stage IV OR metastatic) AND surgery AND ("primary tumour" OR "primary tumor"). English journals were taken into account, and only full papers were included. This resulted in 784 hits. After reviewing the abstracts, eleven retrospective studies were found in which the use of local therapy in primary metastatic breast cancer and its impact on survival was examined. One study was excluded as it did not contain a control group without surgery (Carmichael 2003). ${ }^{17}$ References of selected studies were checked, but no additional studies were found. The literature search was done by two authors (JR and AV). 


\section{Statistical pooling of study results}

Overall survival was the outcome of interest. Breast cancer specific survival was used for studies that did not report overall survival. The decision to combine these outcome measures was justified by the fact that the difference between overall survival and breast cancer specific survival is usually very small because of the poor prognosis of patients with stage IV breast cancer. The hazard ratios (HRs) of the studies were pooled using the Review Manager software (RevMan 5.0.21). ${ }^{18}$ The HR is the preferred statistic for pooling time-to-event outcomes because it incorporates data from the entire Kaplan-Meier curve and allows for censoring. When available, the HR was extracted directly from the papers. The standard errors of the HR estimates were calculated from the reported $95 \%$ confidence intervals $(95 \% \mathrm{Cl})$ or $P$-values using the methods described by Parmar et al.. ${ }^{19}$ These values were analyzed using the generic inverse variance method. A random effects model was used to calculate the overall effect. Pooled results are expressed as $\mathrm{HRs}$ with $95 \% \mathrm{Cl}$. HRs less than one favor surgery and HRs greater than one favor no surgery.

\section{Results}

An overview of the study characteristics is shown in Table 5.1. All ten studies selected for the review were retrospective in design. Seven studies were based on more than 200 patients. For four studies data from population-based registries were used, including up to 16,023 patients in one study. The remaining studies were based on hospital registries, including 147 to 622 patients. Most studies were based on registries from the nineties and onwards, four studies were initiated in the seventies or eighties. In all studies, one third to half of all patients was treated with surgery of the primary tumor.

\section{Univariate results from the individual studies}

A crude analysis, without adjustment for potential confounders, showed that surgical removal of the breast lesion in stage IV disease was associated with a significantly higher overall survival rate $(P<0.05)$ in seven of the ten studies, and a trend towards a better survival in the three remaining studies.

Of the two studies that took into account the surgical margins, one showed that the better survival was only observed in the patients whose primary breast tumor had been removed with free surgical margins, whereas the other study showed that the survival benefit was more pronounced in patients with free surgical margins. ${ }^{7,9}$

The few studies addressing the impact of axillary lymph node dissection did not find a significant contribution of nodal dissection to the prognosis. ${ }^{9,13}$ 


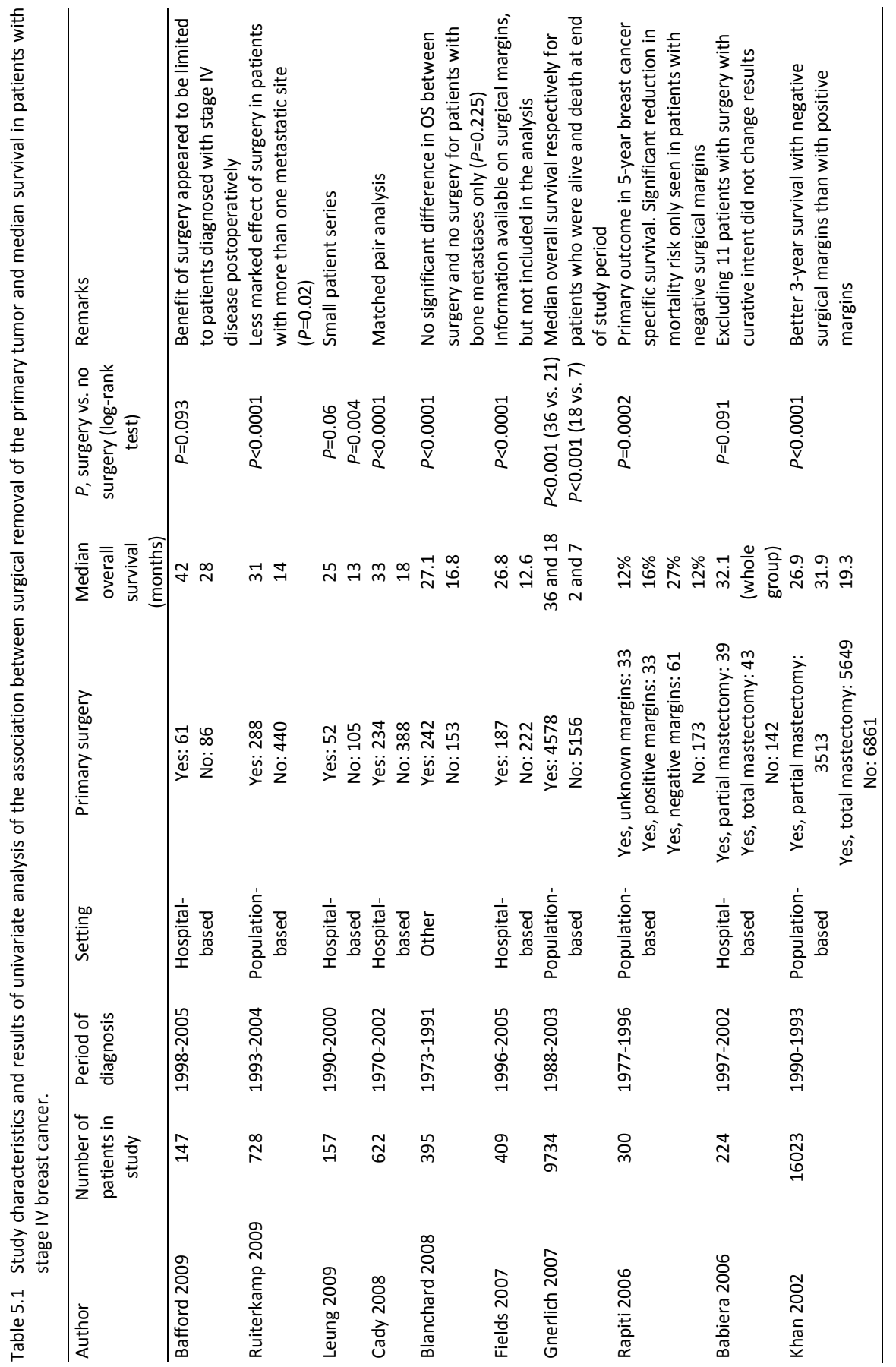




\section{Separate discussion on 'negative' studies}

Three studies did not find a positive effect of surgery on overall survival in patients with primary metastatic breast cancer. ${ }^{14-16}$

Bafford et al. found that, although on multivariate analysis survival was significantly superior in the surgery group (median survival 4.13 years versus 2.36 years; HR 0.47; $P=0.003$ ), this benefit was confined to the patients operated upon before diagnosis of metastatic disease (median survival 4.05 years). ${ }^{14}$ The authors argued that the effect of surgery may be caused by "stage migration bias", meaning that patients who benefited from surgery probably are the ones with smaller breast tumors and asymptomatic metastases, who already had a better overall survival from the start. However, in this study the authors adjusted for age, number of sites of metastases, use of systemic therapy and ER and HER2neu status, thus taking into account possible confounders. A univariate comparison of two subgroups (stage IV diagnosis before or after surgery) with the no-surgery group provides a lower level of evidence compared with the overall multivariate analysis. Therefore, we are not convinced by these data that breast surgery only benefits patients who had a diagnosis of metastatic disease after primary breast surgery.

Leung et al. compared survival between different patient groups. ${ }^{15}$ Median survival for patients who underwent surgery was 25 months, compared with 13 months for patients who did not receive surgery $(P=0.004)$. Of 157 patients, 84 were treated with chemotherapy whereas 73 not. Median survival was 25 months for the patients treated with chemotherapy compared with only 8 months for those not treated with chemotherapy. When taking the effects of chemotherapy into account, surgery by itself no longer appeared to have a significant impact on survival. An obvious limitation of the study, also stated by the authors, is the limited number of patients included.

In the largest 'negative' study, it was suggested that case selection bias and coding errors may explain an important part of the survival advantage observed in stage IV breast cancer patients undergoing surgery. ${ }^{16}$ The investigators used case-matching, according to age, year of diagnosis, site of metastatic disease, hormone receptor status and use of systemic therapy, to make patients with and without surgery more comparable and to remove bias by these factors. Overall, there was a statistically significant survival benefit for patients treated with surgery. Moreover, the evidence pointed at the same direction in the various subgroup-analyses. In nearly all casematched subgroups there was still a significant survival benefit from breast surgery. In some subgroups there was no statistical significance difference, however, the survival curves yet were more favorable for the surgery-treated groups, and lack of significance may have resulted from the small numbers of patients included per subgroup; for example one subgroup contained only eight patients. In conclusion, we consider this study as a positive study with respect to impact of breast surgery in stage IV disease. 


\section{Multivariate analyses from the individual studies}

Interpretation of the results of the univariate analysis is limited by the fact that the decision to remove the primary tumor may have been guided by factors that are themselves related to the outcome of the disease. In most studies, the patients who had surgery were significantly younger compared to the patients who did not had surgery. ${ }^{7-10,12,13}$ These patients had also smaller primary tumors and more often just one metastatic localization. ${ }^{8,9,12,13}$ Some studies reported that patients who had surgery also had less extensive regional disease. ${ }^{8,15}$ The patients who received surgery were also less likely to have concomitant diseases. ${ }^{13}$ They were more likely to be Caucasian and to have tumors with positive estrogen and progesterone receptors. ${ }^{10,12}$ They also received more often local radiotherapy. ${ }^{9,13,14}$ Some studies reported that the use of chemotherapy was lower among women who underwent surgery. ${ }^{9}$ In contrast, other studies found that these women were more likely to receive chemotherapy, hormonal therapy or both than patients who did not have surgery. ${ }^{8,13}$ In one study patients who received surgery were significant older than patients who were not treated with surgery. ${ }^{12}$ Thus, a multivariable analysis is required to adjust for these potential confounders.

In Table 5.2 the results of the studies in which a multivariable analysis has been performed are summarized. In general, results of the univariate analysis were confirmed. Surgery of the primary tumor appeared to be an independent factor for an improved survival in patients with stage IV breast cancer. HRs range from 0.47 to 0.71 . Most studies adjusted for age, tumor size, hormone receptor status and site of metastatic disease. Some of the studies also adjusted for the use of systemic therapy (mostly for chemotherapy), sometimes also for hormonal treatment and radiotherapy, and axillary lymph node status. Only two studies corrected for comorbidity. The following variables with significant impact on survival have been identified: age, estrogen receptor (ER) and progesterone receptor (PR) status, (number of) sites of metastases, use of systemic therapy (chemotherapy and sometimes hormonal treatment) and surgical margins.

\section{Statistical pooling of study results}

HRs for overall mortality and standard errors for the estimated HRs were reported or could be calculated for al studies, except for the study by Cady et al., which was a matched pair analysis, and the study by Leung et al. (Figure 5.1). The papers by Rapiti et al. and Khan et al. did not report the HR for the total group of patients undergoing surgery versus no surgery, but only for patients with free and positive surgical margins (vs. no surgery) separately. The HRs for these subgroups were both included in the pooled analysis, together with the HRs of the other studies (Figure 5.1). For the study by Khan et al., the HR for the patients with positive surgical margins was significantly different from the HR for patients with negative margins. Significant heterogeneity 
was observed by visual inspection of the forest plot and by calculating the Chi-square test for heterogeneity $(P<0.0001)$ and the $\mathrm{I}^{2}$ percentage $(81 \%)$. For that reason a random effects model was chosen to pool the HRs. The pooled HR for overall mortality was $0.65(95 \% \mathrm{Cl} 0.59-0.72)$ in favor of the patients undergoing surgery (Figure 5.1).

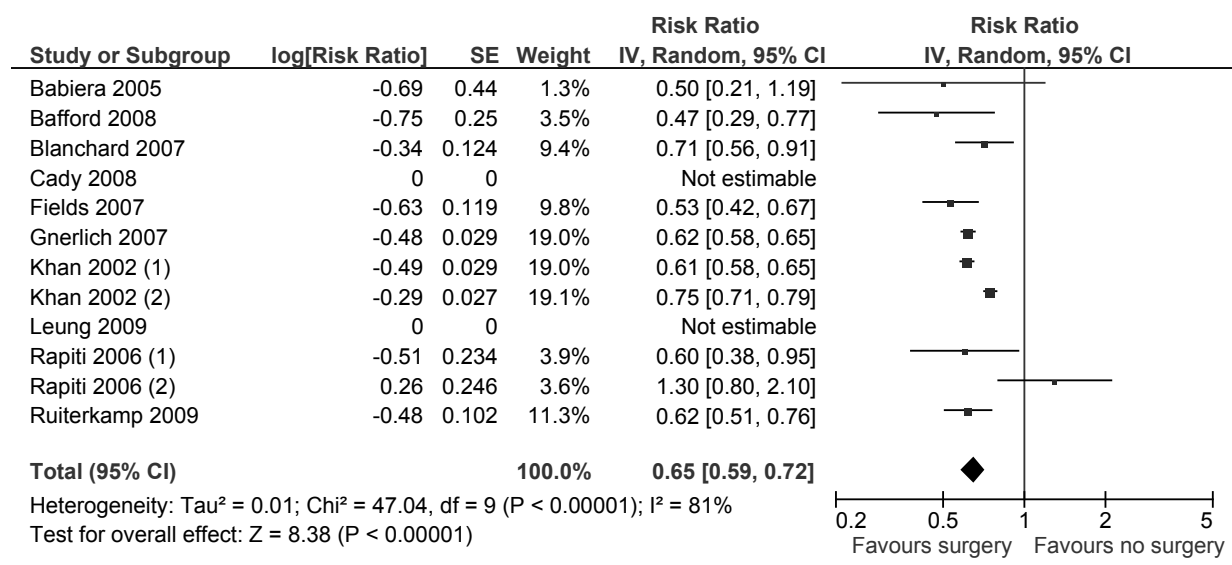

Figure 5.1 Pooled analysis of Hazard Ratios for overall mortality for surgery versus no surgery for patients with stage IV breast cancer.

(1): patients with free surgical margins; (2): patients with positive surgical margins

\section{Discussion}

In this systematic review we weighted the evidence for and against breast surgery in patients with primary metastatic breast cancer. Surgery of the breast tumor was associated with a statistically significant better overall survival in seven of the ten studies, and a trend for significant better survival in the three remaining studies. All studies were non-randomized and conducted retrospectively. Surgery with free surgical margins even caused a larger difference in overall survival. There were several other factors contributing to a better overall survival, like younger age, smaller primary tumor and having just one metastatic site. In the multivariate analyses, there has been a correction for these factors. In retrospective analyses, however, there is still a risk of residual confounding, even if multivariate analyses on known prognostic and therapeutic factors have been performed. Evident limitations of the existing literature are that patients who underwent surgery also receive effective systemic therapy at the same time, whereas patients with a better prognosis are also more likely to get their tumor resected. 


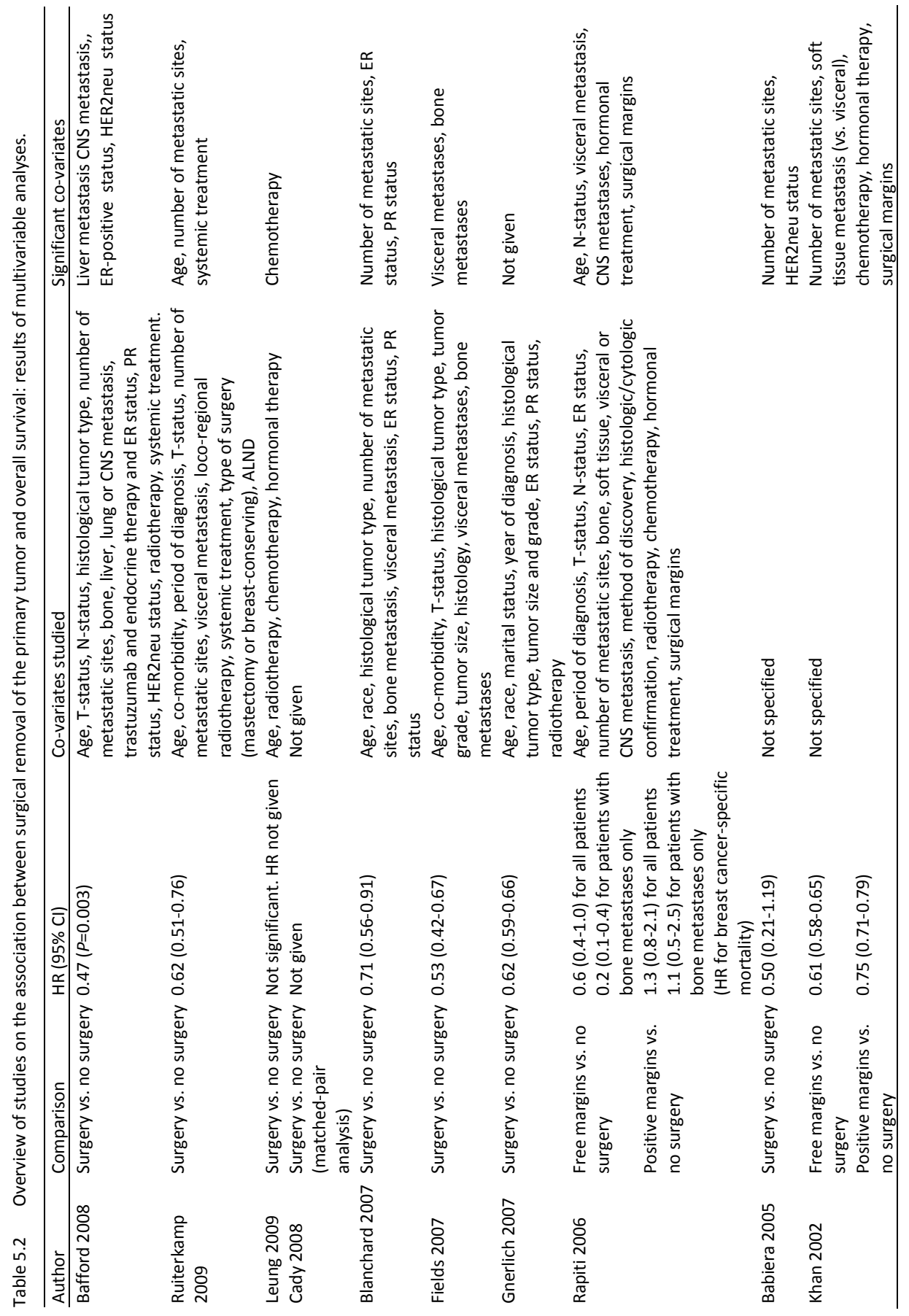


Two recent retrospective studies evaluated whether locoregional treatment, either surgery or radiotherapy, would impact survival apart from protection against uncontrolled chest wall disease and irrespective of treatment of the primary breast tumor. Local control was maintained in $82 \%$ of all patients in the surgical group versus $34 \%$ in the group without surgery $(P=0.001)$. Moreover, chest wall control was associated with improved overall survival regardless of whether surgical resection of the tumor was performed, with a hazard ratio of $0.42(P<0.0002) .{ }^{20}$ Another study also analyzed the effect of locoregional treatment, locoregional radiotherapy and/or surgery, and its effect on overall survival. Patients who received locoregional treatment had a 3 -year survival rate of $43.3 \%$, whereas patients who did not receive locoregional therapy had a 3-year survival rate of $26.7 \%(P=0.00002)$. In multivariable analysis, locoregional treatment was associated with a $30 \%$ reduction in the risk of death (HR: $0.70,95 \% \mathrm{Cl}: 0.58-0.85) .^{21}$

Axillary dissection has been regarded as a staging rather than a therapeutic procedure, but a meta-analysis including nearly 3,000 patients showed an average survival benefit of more than $5 \%$ from axillary lymph node dissection in the nonmetastasized setting. ${ }^{22}$ Several studies now support the idea that uncontrolled regional disease in the axilla can also act as a source for systemic tumor (re)seeding in the metastasized setting. ${ }^{23,24}$ The study of Kahn et al. provides some evidence of an additional beneficial effect of axillary clearance when performed in the same session as the breast tumor removal. ${ }^{7}$ This was confirmed by an other study that shows that patients who underwent an axillary lymph node dissection tended to have a better overall survival than those without axillary dissection, though the difference was restricted to the first year after treatment. ${ }^{13}$

If the total tumor burden really plays a role in survival and the primary tumor can be considered as a metastatic site, then the removal of the breast lesion is part of a multimodality strategy in preventing further growth and dissemination of the disease. ${ }^{6}$ This hypothesis was confirmed by several studies which found a strong correlation between the level of circulating tumor cells (CTCS) and the prognosis of metastatic breast cancer by showing that the number of circulating tumor cells before treatment is an independent predictor of overall survival in patients with metastatic breast cancer. ${ }^{25-27}$ Also patients who after treatment converted from elevated CTCs to nonelevated levels show a clinical response. ${ }^{28}$ Thereby, an association is found between the median CTC level, determined in the course of the treatment, and the time to progression in metastatic breast cancer. ${ }^{29}$ This may indicate that the clinical response is correlated with a decrease in CTCs and thus with a reduction of tumor burden. 
Improvement in survival can also be caused by the fact that surgical resection restores the immune system, even in patients with metastatic disease. ${ }^{30}$ Tumor-induced immunosuppression is a mechanism allowing tumors to escape immune destruction. It is thought that immunosuppression intensifies with increasing tumor burden. Surgery reduces the quantity of immunosuppressive factors and allowing the immune response to recover. Opposite to the proposed biological mechanisms in favor of surgical removal of the primary tumor, there have been observations indicating that surgical resection of the breast lesion in metastatic disease may accelerate relapse by two mechanisms: 1 . due to removal of inhibitors of angiogenesis there will be an angiogenic surge; 2 . surgical wounding will lead to the release of growth and immunosuppressive factors. ${ }^{10,31}$ Some other studies also suggest that the growth of distant metastases even may be stimulated after the primary breast tumor has been removed, this hypothesis is partly sustained by experimental studies and partly by doctor's personal experience. ${ }^{32}$ Our analysis of available retrospective studies does not support this view.

In conclusion, our literature review suggests that surgery of the primary breast tumor in patients with stage IV disease at initial presentation does have a positive impact on survival. In order to provide a definite answer on whether local tumor control in patients with primary metastatic disease improves survival, a randomized controlled trial comparing systemic therapy with or without breast surgery is needed. Such a trial may run for many years to include enough patients, but we feel that this next step is logical in the light of the retrospective evidence. In the Netherlands as well as in the United States plans for such a trial are made. In such prospective trials, it may also be feasible to add quality of life questionnaires, in order to determine psychological effects of locoregional treatment. Hopefully these efforts will result in an evidence based conclusion on this very important subject of the treatment of patients with primary metastatic breast cancer. 


\section{References}

1. Hédelin G, Macè-Lesech J, Garcia CM, Møller H, Paci E, Raverdy N, Tretarre B, Williams EM; European Concerted Action on Survival and Care of Cancer Patients (EUROCARE) Working Group. Breast carcinoma survival in Europe and the United States. Cancer 2004;100:715-722

2. Ellis MJ, Hayes DF, Lippman ME. Treatment of metastatic breast cancer. In: Harris J et al. (ed) Diseases of the breast, 2nd edn. Williams and Wilkins, Philadelphia, 2000:749-797

3. Wood WC, Muss HB, Solin LJ, Olopade OI. Malignant tumors of the breast. In: DeVita VT Jr, Hellman S, Rosenberg SA. Cancer Principles and Practice of Oncology, 7th edn, 2005:1415-1478

4. Ernst MF, van de Poll-Franse LV, Roukema JA, Coebergh JW, van Gestel CM, Vreugdenhil G, Louwman MJ, Voogd AC. Trends in the prognosis of patients with primary metastatic breast cancer diagnosed between 1975 and 2002. Breast 2002;16:344-351

5. Miller K, Wang M, Gralow J, Dickler M, Cobleigh M, Perez EA, Shenkier T, Cella D, Davidson NE. Paclitaxel plus bevacizumab versus paclitaxel alone for metastatic breast cancer. N Engl J Med 2007;357: 26:2666-2676

6. Amar S, Roy V, Perez EA. Treatment of metastatic breast cancer: looking towards the future. Breat Cancer Res Treat 2009;114:413-422

7. Khan SA, Stewart AK, Morrow M. Does aggressive local therapy improve survival in metastatic breast cancer. Surgery 2002;132:620-627

8. Babiera GV, Rao R, Feng L, Meric-Bernstam F, Kuerer HM, Singletary SE, Hunt KK, Ross MI, Gwyn KM, Feig BW, Ames FC, Hortobagyi GN. Effect of primary tumor extirpation in breast cancer patients who present with stage IV disease and an intact primary tumor. Ann of Surg Oncol 2006;13:776-782

9. Rapiti E, Verkooijen HM, Vlastos G, Fioretta G, Neyroud-Caspar I, Sappino AP, Chappuis PO, Bouchardy C.) Complete surgical excision of primary breast tumor improves survival of patients with metastatic breast cancer at diagnosis. J Clin Oncol 2006;24:2743-2749

10. Gnerlich J, Jeffe DB, Deshpande AD, Beers C, Zander C, Margenthaler JA. Surgical removal of the primary tumor increases overall survival in patients with metastatic breast cancer: Anlysis of the 19882003 SEER data. Ann of Surg Oncol 2007; 14:2187-2194

11. Fields RC, Jeffe DB, Trinkaus K, Zhang Q, Arthur C, Aft R, Dietz JR, Eberlein TJ, Gillanders WE, Margenthaler JA. Surgical resection of the primary tumor is associated with increased long-term survival in patients with stage IV breast cancer after controlling for site of metastasis. Ann Surg Oncol 2007; 14:3345-3351

12. Blanchard DK, Shetty PB, Hilsenbeck SG, Elledge RM. Association of surgery with improved survival in stage IV breast cancer patients. Ann Surg 2008;247:732-738

13. Ruiterkamp J, Ernst MF, van de Poll-Franse LV, Bosscha K, Tjan-Heijnen VC, Voogd AC. Surgical resection of the primary tumour is associated with improved survival in patients with distant metastatic breast cancer at diagnosis. Eur J Surg Oncol 2009;35:1146-1151.

14. Bafford AC, Burstein HJ, Barkley CR, Smith BL, Lipsitz S, Iglehart JD, Winer EP, Golshan M. Breast surgery in stage IV breast cancer: impact of staging and patient selection on overall survival. Breast Cancer Res Treat 2009;115:7-12

15. Leung AM, Vu HN, Nguyen KA, Thacker LR, Bear HD. Effects of surgical excision on survival of patients with stage IV breast cancer. J Surg Res 2010;161:83-8.

16. Cady B, Nathan NR, Michaelson JS, Golshan M, Smith BL. Matched pair analyses of stage IV breast cancer with or without resection of primary breast site. Ann Surg Oncol 2008;15:3384-3395

17. Carmichael AR, Anderson EDC, Chetty U, Dixon JM. Does local surgery have a role in the management of stage IV breast cancer? Eur J Surg Oncol 2003;29:17-19

18. Review Manager (RevMan) [Computer program]. Version 5.0. Copenhagen: The Nordic Cochrane Centre, The Cochrane Collaboration. 2008

19. Parmar MKB, Torri V, Stewart L. Extracting summary statistics to perform meta-analyses of the published literature for survival endpoints. Stat Med 1998;17:2815-2834

20. Hazard WH, Gorla SR, Scholtens D, Kiel K, Gradishar WJ, Khan SA. Surgical resection of the primary tumor, chest wall control, and survival in women with metastatic breast cancer. Cancer 2008;113: 2011-2019 
21. Le Scodan R, Stevens D, Brian E, Floiras JL, Cohen-Solal C, De La Lande B. Breast cancer with synchronous metastases: survival impact of exclusive localregional radiotherapy. J Clin Oncol 2009;27: 1375-1381

22. Orr RK. The impact of prophylactic axillary node dissection on breast cancer survival - A Bayesian meta-analysis. Ann Surg Oncol 1998;6:109-116

23. Ragaz J, Jackson SM, Le N, Plenderleith IH, Spinelli JJ, Basco VE, Wilson KS, Knowling MA, Coppin CM, Paradis $\mathrm{M}$, Coldman AJ, Olivotto IA. Adjuvant radiotherapy and chemotherapy in node-positive premenopausal women with breast cancer. N Engl J Med 1997;337:956-962

24. Overgaard M, Hansen PS, Overgaard J, Rose C, Andersson M, Bach F, Kjaer M, Gadeberg CC, Mouridsen HT, Jensen MB, Zedeler K. Postoperative radiotherapy in high-risk premenopausal women with breast cancer who receive adjuvant chemotherapy. N Engl J Med 1997;337:949-955

25. Budd GT, Cristofanilli M, Ellis MJ, Stopeck A, Borden E, Miller MC, Matera J, Repollet M, Doyle GV, Terstappen LWMM, Hayes DF. Circulating tumor cells versus imaging - predicting overall survival in metastatic breast cancer. Cancer Res 2006;12:6403-6409

26. Cristofanilli M, Budd GT, Ellis MJ, Stopeck A, Matera J, Miller MC, Reuben JM, Doyle GV, Allard WJ, Terstappen LW, Hayes DF. Circulating tumor cells, disease progression, and survival in metastatic breast cancer. N Engl J Med 2004;351:781-791

27. Cristofanilli M, Hayes DF, Budd GT, Ellis MJ, Stopeck A, Reuben JM, Doyle GV, Matera J, Allard WJ, Miller MC, Fritsche HA, Hortobagyi GN, Terstappen LW. Circulating tumor cells: a novel prognostic factor for newly diagnosed metastatic breast cancer. J Clin Oncol 2005;23:1420-1430

28. Hayes DF, Cristofanilli M, Budd GT, Ellis M, Stopeck A, Miller MC, Matera J, Allard WJ, Doyle GV, Terstappen LWWM. Circulating tumor cells at each follow-up time point during therapy of metastatic breast cancer patients predict progression-free and overall survival. Clin Cancer Res 2006;12: 4218-4224

29. Wong NS, Kahn HJ, Zhang L, Oldfield S, Yang LY, Marks A, Trudeau ME. Prognostic significance of circulating tumour cells enumerated after filtration enrichment in early and metastatic breast cancer patients. Breast Cancer Res Treat 2006;99:96-93

30. Danna EA, Sinha P, Gilbert M, Clements VK, Pulaski BA, Ostrand-Rosenberg S. Surgical removal of primary tumor reverses tumor-induced immunosuppression despite the presence of metastatic disease. Cancer Res 2004;64:2205-2211

31. Retsky M, Bonadonna G, Demicheli R, Folkman J, Hrushesky W, Valagussa P. Hypothesis: induced angiogenesis after surgery in premenopausal node-positive breast cancer patients is a major underlying reason why adjuvant chemotherapy works particularly well for those patients. Breast Cancer Res 2004;6:372-374

32. Baum M, Demicheli R, Hrushesky W, Retsky M. Does surgery unfavourably perturb the "natural history" of early breast cancer by accelerating the appearance of distant metastases? Eur J Cancer 2005;41:508-515 


\section{CHAPTER 6}

SYSTEMIC THERAPY WITH OR WITHOUT UP FRONT SURGERY OF THE PRIMARY TUMOR IN BREAST CANCER PATIENTS WITH DISTANT METASTATIC DISEASE AT INITIAL PRESENTATION

SUBMIT study protocol

J Ruiterkamp AC Voogd

VCG Tjan-Heijnen

K Bosscha

YM van der Linden

EJTh Rutgers

E Boven

MJC van der Sangen

MF Ernst 


\section{Abstract}

\section{Objective}

Five percent of all patients with breast cancer have distant metastatic disease at initial presentation. Because metastatic breast cancer is considered to be an incurable disease, it is generally treated with a palliative intent. Recent non-randomized studies have demonstrated that (complete) resection of the primary tumor is associated with a significant improvement of the survival of patients with primary metastatic breast cancer. However, other studies have suggested that the claimed survival benefit by surgery may be caused by selection bias. Therefore, a randomized controlled trial will be performed to assess whether breast surgery in patients with primary distant metastatic breast cancer will improve the prognosis.

\section{Methods}

Randomization will take place after the diagnosis of primary distant metastatic breast cancer. Patients will either be randomized to up front surgery of the breast tumor followed by systemic therapy or to systemic therapy, followed by delayed local treatment of the breast tumor if clinically indicated.

Patients with primary distant metastatic breast cancer, with no prior treatment of the breast cancer, who are 18 years or older and fit enough to undergo surgery and systemic therapy are eligible. Important exclusion criteria are: prior invasive breast cancer, surgical treatment or radiotherapy of this breast tumor before randomization, irresectable T4 tumor and synchronous bilateral breast cancer. The primary endpoint is 2-year survival. Quality of life and local tumor control are among the secondary endpoints.

Based on the results of prior research it was calculated that 258 patients are needed in each treatment arm, assuming a power of $80 \%$. Total accrual time is expected to take 60 months. An interim analysis will be performed to assess any clinically significant safety concerns and to determine whether there is evidence that up front surgery is clinically or statistically inferior to systemic therapy with respect to the primary endpoint.

\section{Conclusions}

The SUBMIT study is a randomized controlled trial that will provide evidence on whether or not surgery of the primary tumor in breast cancer patients with metastatic disease at initial presentation results in an improved survival. 


\section{Introduction}

In most western countries, around five percent of all patients with breast cancer have distant metastatic disease at initial presentation. ${ }^{1,2}$ This accounts for 500 newly diagnosed patients each year in the Netherlands. ${ }^{1}$ Because metastatic breast cancer is considered to be an incurable disease, the aim of the treatment for these patients is to provide palliation amongst mothers with systemic therapy. Usually, breast surgery is restricted to those patients in whom the breast tumor is symptomatic. The rationale behind this strategy is based on the fact that once distant metastases have occurred, (aggressive) local therapy provides no survival advantage.

Research on the effect of systemic therapy in women with metastatic disease has demonstrated that their prognosis has improved significantly during the last 10 to 15 years, primarily due to increased efficacy of chemotherapy and the introduction of targeted treatments. ${ }^{2-4}$ Recent retrospective studies have demonstrated that resection of the breast tumor in patients with primary metastatic breast cancer is associated with a significant improvement of the prognosis (Table 6.1). ${ }^{5-12}$ The hazard ratios $(H R)$ for overall survival in these studies ranged from 0,50 to 0,71 in favor of surgery of the breast tumor. Furthermore, in studies taking surgical resection margins into account, better survival was observed in patients with a primary breast lesion that had been removed with free surgical margins. ${ }^{5,7,13}$ In the review of Ruiterkamp et al. a pooled HR of 0.65 (95\% confidence interval 0.59-0.72) was calculated for overall survival for surgery versus no surgery, in favor of surgery (Figure 6.1). ${ }^{14}$ Results of a stratified analysis, done by Rapiti et al. suggest a greater effect for surgery among women with only bone metastases at diagnosis. ${ }^{7}$

Table 6.1 Results of retrospective studies.

\begin{tabular}{|c|c|c|c|c|c|c|c|c|c|}
\hline \multirow[t]{3}{*}{ Author } & \multirow[t]{3}{*}{ Year } & \multirow{3}{*}{$\begin{array}{c}\mathrm{Nr} \text { of } \\
\text { patients }\end{array}$} & \multirow{3}{*}{$\begin{array}{c}\text { Surgery } \\
(\%)\end{array}$} & \multirow[t]{3}{*}{$\mathrm{HR}$} & \multirow[t]{3}{*}{$95 \% \mathrm{Cl}$} & \multicolumn{4}{|c|}{ Median survival (months) } \\
\hline & & & & & & \multicolumn{3}{|c|}{ Surgery } & \multirow[t]{2}{*}{ No surgery } \\
\hline & & & & & & Not specified & Lumpec & Mastec & \\
\hline Khan $^{5}$ & 2002 & 16023 & 57 & 0.61 & $0.58-0.65$ & - & 27 & 32 & 19 \\
\hline Babiera $^{6}$ & 2006 & 224 & 37 & 0.50 & $0.21-1.19$ & - & & & - \\
\hline Rapiti $^{7}$ & 2006 & 300 & 42 & 0.60 & $0.4-1.0$ & $-{ }^{a}$ & & & - \\
\hline Fields $^{8}$ & 2007 & 409 & 46 & 0.53 & $0.42-0.67$ & 32 & & & 15 \\
\hline Gnerlich $^{9}$ & 2007 & 9734 & 47 & 0.63 & $0.60-0.66$ & 36 & & & 21 \\
\hline Blanchard $^{10}$ & 2008 & 395 & 61 & 0.71 & $0.56-0.91$ & 27 & & & 17 \\
\hline Cady $^{\text {b } 15}$ & 2008 & 622 & 38 & - & - & - & & & - \\
\hline Bafford $\left.^{16}\right]$ & 2009 & 147 & 41 & 0.47 & - & 42 & & & 28 \\
\hline Ruiterkamp $^{11}$ & 2009 & 728 & 40 & 0.62 & $0.51-0.76$ & 31 & & & 14 \\
\hline Leung $^{17}$ & 2009 & 157 & 33 & - & - & 25 & & & 13 \\
\hline Neuman $^{12}$ & 2010 & 186 & 37 & 0.71 & $0.47-1.06$ & 40 & & & 33 \\
\hline Dominici $^{\text {b } 18}$ & 2011 & 290 & 23 & 0.94 & $0.83-1.08$ & 42 & & & 41 \\
\hline
\end{tabular}

$\mathrm{HR}=$ Hazard ratio; $95 \% \mathrm{Cl}=95 \%$ confidence interval. ${ }^{\text {a }}$ Rapiti: 5 -year specific survival; $27 \%$ for surgery with negative margins, $16 \%$ for surgery with positive margins, $12 \%$ for surgery with unknown margins and $12 \%$ for no surgery. ${ }^{b}$ Case-matched analysis 


\begin{tabular}{|c|c|c|c|c|c|c|}
\hline Study or Subgroup & log[Risk Ratio] & SE & Weight & $\begin{array}{c}\text { Risk Ratio } \\
\text { IV, Random, } 95 \% \mathrm{CI}\end{array}$ & $\begin{array}{r}\text { Ris! } \\
\text { IV, Rand } \\
\end{array}$ & $\begin{array}{l}\text { k Ratio } \\
\text { dom, } 95 \% \mathrm{Cl}\end{array}$ \\
\hline Babiera 2005 & -0.69 & 0.44 & $1.3 \%$ & $0.50[0.21,1.19]$ & & \\
\hline Bafford 2008 & -0.75 & 0.25 & $3.5 \%$ & $0.47[0.29,0.77]$ & & \\
\hline Blanchard 2007 & -0.34 & 0.124 & $9.4 \%$ & $0.71[0.56,0.91]$ & & \\
\hline Cady 2008 & 0 & 0 & & Not estimable & & \\
\hline Fields 2007 & -0.63 & 0.119 & $9.8 \%$ & $0.53[0.42,0.67]$ & & \\
\hline Gnerlich 2007 & -0.48 & 0.029 & $19.0 \%$ & $0.62[0.58,0.65]$ & $=$ & \\
\hline Khan 2002 (1) & -0.49 & 0.029 & $19.0 \%$ & $0.61[0.58,0.65]$ & $=$ & \\
\hline Khan 2002 (2) & -0.29 & 0.027 & $19.1 \%$ & $0.75[0.71,0.79]$ & 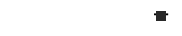 & \\
\hline Leung 2009 & 0 & 0 & & Not estimable & & \\
\hline Rapiti 2006 (1) & -0.51 & 0.234 & $3.9 \%$ & $0.60[0.38,0.95]$ & & \\
\hline Rapiti 2006 (2) & 0.26 & 0.246 & $3.6 \%$ & $1.30[0.80,2.10]$ & & \\
\hline Ruiterkamp 2009 & -0.48 & 0.102 & $11.3 \%$ & $0.62[0.51,0.76]$ & & \\
\hline Total $(95 \% \mathrm{Cl})$ & & & $100.0 \%$ & $0.65[0.59,0.72]$ & & \\
\hline \multicolumn{7}{|c|}{ 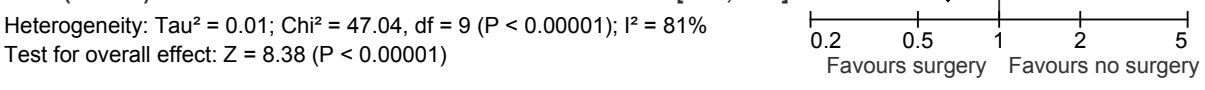 } \\
\hline
\end{tabular}

Figure 6.1 Pooled analyses of hazard ratios for overall mortality for surgery versus no surgery for patients with stage IV breast cancer ${ }^{14}$.

(1): patients with free surgical margins; (2): patients with positive surgical margins

In all these aforementioned studies, the decision to perform surgery could have been influenced by favorable prognostic factors, such as younger age, the presence of only one metastatic site or a good response to systemic therapy. To rule out the impact of potential confounders, most studies adjusted for age, tumor size, number and sites of metastases and hormone receptor status. In addition, some studies also adjusted for comorbidity or surgical margins.

More recent studies have investigated the role of additional confounding factors, such as timing of surgery, selection bias and coding errors, and came to the conclusion that the survival benefit seen in patients who were treated with a surgical resection of the primary tumor was not so strong or may have been explained by these confounders. ${ }^{15-18}$ For example, in the study of Bafford et al., the benefit of surgery seemed confined to patients operated upon before diagnosis of metastatic disease and there was no survival advantage in patients who received an operation of the breast tumor after the diagnosis of the metastatic disease had taken place. This phenomenon was referred to as stage migration bias. ${ }^{16,18}$ In a study by Leung et al., the benefit from surgery disappeared in the multivariate analysis when taking into account the use of chemotherapy. ${ }^{17}$ Finally, in a study by Cady et al. coding errors in the retrospectively collected dataset were found to explain part of survival advantage. $^{15}$

Given the nature of retrospective analysis, it is not possible to provide a definite answer to the question whether surgical therapy of the breast tumor indeed affects overall survival. Therefore, in the Netherlands a randomized controlled trial (RCT) has 
been initiated and will start recruiting in the second half of 2011. This study is called, the SUBMIT trial, an acronym for 'Systemic therapy with or without Up front surgery of the primary tumor in Breast cancer patients with distant Metastases at Initial presenTation'. In the current paper we will present the design of this trial.

\section{Methods}

The aim of the SUBMIT study is to investigate the effect of surgery of the primary tumor in breast cancer patients with distant metastatic disease at initial diagnosis. After diagnosis of primary distant metastatic breast cancer, patients will be randomly allocated in two groups: A. Up front breast surgery followed by systemic therapy; B. Systemic therapy potentially followed by delayed local treatment of the breast tumor (Figure 6.2).

\begin{tabular}{|c|c|c|c|c|c|c|}
\hline \multicolumn{6}{|c|}{ Patients with primary distant metastatic breast cancer (M1) } & -2 weeks \\
\hline \multicolumn{6}{|c|}{ Check in/exclusion criteria } & -1 week \\
\hline \multicolumn{6}{|c|}{ Randomization after informed consent } & \multirow[b]{2}{*}{$\mathrm{T}=0$} \\
\hline & & & & & & \\
\hline $\begin{array}{l}\text { Group A } \\
\text { (UFS) }\end{array}$ & \multicolumn{4}{|c|}{ Group B (ST) } & \multirow{4}{*}{ 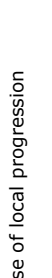 } & \\
\hline Surgery & \multicolumn{4}{|c|}{ Systemic therapy } & & Week 1-4 \\
\hline $\begin{array}{l}\text { Systemic } \\
\text { therapy }\end{array}$ & & & & & & Month 2-3 \\
\hline Tumor evaluation & \multicolumn{4}{|c|}{ Tumor evaluation } & & Month 3-4 \\
\hline $\begin{array}{l}\text { Systemic } \\
\text { therapy }\end{array}$ & \multicolumn{4}{|c|}{ Systemic therapy } & $\widehat{\widehat{a}}$ & Month 4-5 \\
\hline \multirow[b]{2}{*}{ Tumor evaluation } & \multicolumn{4}{|c|}{ Evaluation systemic response } & 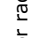 & \multirow[b]{2}{*}{ Month 5-6 } \\
\hline & \multicolumn{2}{|c|}{ Progression } & $\begin{array}{l}\text { Stable } \\
\text { disease }\end{array}$ & $\begin{array}{l}\text { Responsive } \\
\text { disease }\end{array}$ & $\begin{array}{l}\geq \\
\frac{1}{0} \\
0 \\
\frac{5}{5} \\
0\end{array}$ & \\
\hline $\begin{array}{l}\text { Systemic } \\
\text { therapy }\end{array}$ & 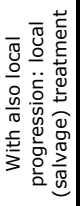 & 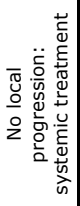 & 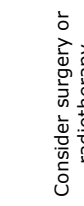 & 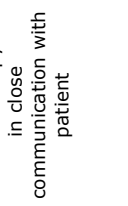 & 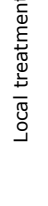 & Month 6-7 \\
\hline \multicolumn{6}{|c|}{ Left to the discretion of responsible physician } & From month 7 \\
\hline
\end{tabular}

Figure 6.2 Study design. 


\section{Patient selection criteria}

The eligibility criteria for the study are:

- primary distant metastatic breast cancer (M1); metastases diagnosed within one month after the diagnosis of the breast cancer

- an anticipated survival of at least 6 months;

- a histologically proven diagnosis of the breast tumor;

- a known hormonal and HER2Neu status;

- TNM classification: T1-T3, resectable T4 status and N0-N3;

- performance status and comorbidity should allow surgery and/or systemic therapy;

- age $\geq 18$ years;

- written informed consent.

Exclusion criteria are:

- a primary invasive breast cancer in the medical history;

- another malignancy within the last 10 years, besides basal cell carcinoma of the skin or early stage cervical cancer;

- surgical treatment and/or radiotherapy of the breast tumor before randomization;

- irresectable T4 breast tumor;

- synchronous bilateral breast cancer.

\section{Randomization}

Centralized randomization will take place immediately after the diagnosis of primary distant metastatic breast cancer, using a computer-generated randomization list. Patients either randomize for up front surgery of the breast tumor followed by systemic therapy or for systemic therapy possibly followed by local treatment of the breast tumor if clinically indicated.

The randomization will be balanced by minimization, according to the minimization algorithm of Pocock and Simon ${ }^{19}$, for: centre, age (18-49, 50-69, $\geq 70$ years), dominant location of distant metastases (bone, soft tissue (lymph nodes and subcutaneous metastases) and visceral metastases), hormonal receptor status (ER and/or PR positive or both negative) and HER2Neu status (overexpression yes or no).

Randomization will be performed centrally, using a website with electronic data-entry to check treatment eligibility. 


\section{Hypotheses}

The following three hypotheses will be tested:

1. Up front breast surgery in patients with primary distant metastatic breast cancer will result in a significant improvement of the 2-year survival compared to the survival achieved with palliative systemic therapy followed by delayed local treatment or systemic therapy alone.

2. Local tumor control in these patients will be superior in case of up front breast surgery compared to patients who receive systemic treatment with delayed local therapy or systemic therapy alone.

3. Better local control, by the use of up front breast surgery, results in a better quality of life in patients with Stage IV breast cancer, compared to patients who receive systemic treatment with delayed local therapy or systemic therapy alone.

\section{Ethical approval}

The study is approved by the one of the Dutch Medical Ethics Committees (METOPP; Medisch-Ethische Toetsing Onderzoek Patiënten en Proefpersonen, Tilburg). The project number is NL30331.028.11. The METOPP is an Ethical Review Committee according to the Dutch Medical Research Involving Human Subjects Act (WMO: Wet Medisch-Wetenschappelijk Onderzoek met Mensen). This study will be carried out in compliance with the Helsinki Declaration. ${ }^{20}$

\section{Settings and location}

The study is a multicenter randomized controlled trial, which will be conducted in the Netherlands. Both academic and regional hospitals are allowed to participate, and already 25 centers are willing to participate.

\section{Treatment options}

During the study patients can be treated with surgery of the primary tumor (depending on randomization), systemic therapy and/or locoregional radiotherapy. The different treatment modalities are described below.

\section{Surgery of the primary tumor and axillary lymph node dissection}

Patients who are randomized to up front surgery of the breast tumor will receive a lumpectomy or mastectomy depending on patient and tumor characteristics. Both types of surgery may be conducted as long as the intention is a complete resection of the primary tumor, which is defined as having succeeded in obtaining free resection 
margins for the invasive component. In case of the presence of involved margins (more than focally) there are three options:

- to perform a re-excision or mastectomy (preferred options in up front surgery group);

- to treat the patient with locoregional radiotherapy;

- to accept that a non-radical resection has been performed.

What to decide belongs to the responsibility of the treating physician; he or she is not bound by restrictions in the protocol.

Also the choice to perform an axillary lymph node dissection is left to the discretion of the treating physician, but is highly recommended if palpable and/or tumor positive lymph nodes in the axillary region are present.

If patients are randomized for systemic therapy, they may still be candidates for surgery of the primary tumor. In case of local progression breast surgery is allowed at any time to gain local control, but preferentially not within the initial 5-6 months of first-line systemic therapy. Surgery for this group is primary indicated when the treating physician beliefs the tumor may cause wound problems in near future, despite use of systemic therapy.

\section{Locoregional radiotherapy}

There are two situations where radiotherapy to the breast or chest wall should be considered. First after an irradical lumpectomy or mastectomy. Irradicality in this trial is defined as involved margins for invasive breast cancer. The second situation is in case of local progression in patients in group $B$ where a non invasive local therapy with radiotherapy is a treatment option instead of surgery. In case of clinically positive axillary lymph nodes, radiotherapy may be a viable treatment option instead of surgery as well. In both situations a hypofractionated regimen is mandatory without too much delay in systemic therapy, if applicable. Of note, - if considered indicated radiotherapy can be postponed after first-line chemotherapy has been delivered. Concurrent radiotherapy and chemotherapy is not allowed because of expected excessive toxicity.

Radiotherapy may also be indicated for distant metastases, such as painful bone metastases or brain metastases.

\section{Systemic therapy}

Patients will be treated with systemic therapy according to the guidelines from the NAtional Breast cancer Organization of the Netherlands (NABON) for treatment of breast cancer. The choice of initial chemotherapy, immunotherapy and endocrine therapy depends - among others - on ER and PR and HER2Neu status, dominant site of distant metastases, age, performance status and comorbidity; but may also depend on the chance to reach a complete remission for example in minimal metastatic disease. In patients with a hormone receptor positive tumor, hormonal treatment is 
indicated. In case of rapid progression, chemotherapy is the treatment of choice. In HER2Neu positive disease and the use of an aromatase inhibitor, it is possible to add HER2Neu targeted therapy. Chemotherapy is offered to patients with hormone receptor negative status, with extensive and fast growing visceral metastases and with severe cytopenia. For this study we advice to use at least an anthracycline, a taxane and capecitabine for the first 2-3 lines of treatment. The order is left to the discretion of the treating physician, if necessary in combination with targeted therapy, such as bevacizumab or HER2Neu targeted therapy, according to local practice. Patients with HER2Neu overexpression, can be treated with a combination of trastuzumab and taxanes as first-line chemotherapy. At first line treatment one may also choose for anthracycline containing chemotherapy, without HER2Neu targeted therapy. During the following lines of chemotherapy, continuing HER2Neu blocking with trastuzumab or lapatinib is advised.

\section{Primary and secondary outcome measures}

The primary endpoint is the two-year survival. This is defined as the percentage of patients who survive two years after randomization. Secondary endpoints are quality of life, overall survival, number of unplanned local therapies, i.e. surgery or radiotherapy, number of axillary lymph node dissections or axillary radiotherapy, determination of pathological resection margin (margin status) in patients treated by surgery of the primary tumor and type of chemotherapy, immunotherapy and endocrine therapy and number of regimens of systemic therapy during the first 2 years.

\section{Statistics}

\section{Sample size calculation}

In a previous, retrospective, study performed in the south of the Netherlands, the median survival of patients with stage IV breast cancer who had surgery was 31 months, as compared to 14 months for patients who did not have surgery $(P<.0001) .{ }^{11}$ In a multivariable Cox regression analysis, adjusting for age, period of diagnosis, T-classification, number of metastatic sites, co-morbidity, use of locoregional radiotherapy and use of systemic therapy, the HR of breast surgery for overall mortality in this study was 0.62 (95\% confidence interval $(\mathrm{Cl}) 0.51-0.76)$. In a recently published meta-analysis, including the results of 9 retrospective studies, the pooled HR for overall mortality was 0.65 (95\% $\mathrm{Cl} 0.59-0.72){ }^{14}$

We are planning a randomized controlled trial with an equal number of patients in both treatment arms, an accrual interval of 60 months, and additional follow-up after the accrual interval of 18 months. We assume that (as a result of more effective systemic treatments) the median survival time of the patients without surgery has 
improved to 18 months since 2004, which was the last period of diagnosis included in the retrospective study based on the data from the Eindhoven Cancer Registry. ${ }^{1}$ If the true hazard ratio (relative risk) of the patients with upfront surgery relative to the patients with immediate start of systemic therapy is 0.76 (the upper boundary of the $95 \% \mathrm{Cl}$ of the retrospective study, performed in the south of the Netherlands by Ruiterkamp et al. ${ }^{11}$ ), we will need to study 248 patients with up front surgery and 248 without up front surgery to be able to reject the null hypothesis that the survival curves are equal with a probability (power) of 0.80 . The Type I error probability associated with this test of this null hypothesis is 0.05 . An additional number of 20 patients will be included to account for loss to follow-up and/or exclusion after randomization because of violation of the eligibility criteria; so total accrual consists of 516 patients.

\section{Data analysis}

Investigators will enter the information required by the protocol into the Case Report Forms (CRFs). The data from all centers will be pooled and summarized with respect to demographic and baseline characteristics and efficacy and safety observations. Data will be presented for the complete intent-to-treat population. The primary endpoint will be analyzed in a Cox regression model, with the minimization factors as covariables.

\section{Interim analysis}

An interim analysis will be performed after $50 \%$ (258 patients) of the total required number of patients has been included. The purpose of this interim review is to assess any clinically significant safety concerns and to determine whether there is evidence that up front surgery (treatment A) is clinically or statistically inferior to immediate systemic therapy without up front surgery (treatment B), with respect to the primary endpoint. To control the overall type I error when performing the interim analysis, the Peto approach will be used to ensure an overall Type I error of $5 \% .{ }^{21,22}$ A one-sided significance level of 0.001 will be used at the interim analysis.

\section{Discussion}

Recent studies on surgery of the breast tumor in patients with primary distant metastatic disease are inconclusive regarding the effect of surgery on overall survival. Most indicate that surgical treatment is associated with a significantly improved overall survival $^{5-12}$, but some state that this benefit is caused by confounding, induced by the retrospective study designs. ${ }^{15-18}$ In order to provide a definite answer with respect to the role of surgery in primary metastatic breast cancer, a prospective 
randomized controlled trial, the SUBMIT study, is about to be initiated within The Netherlands. If surgery is shown to be associated with improved survival, it would also be interesting to know more about the biological mechanisms which underly the effect. Therefore, research on circulating tumor or endothelial cells in blood, the immune response and the angiogenic potential of metastases will be considered within the trial. A grant application for a side-study, in which circulating tumor cells (CTCS) will be enumerated and characterized for HER2Neu expression and estrogen receptor status, has already been submitted. This side-study would enable us to address the hypothesis that among patients with a HER2Neu negative primary tumor those with HER2Neu positive CTCS have a worse outcome to standard systemic treatment compared to those with HER2Neu negative CTCs. Additionally, the impact of primary tumor resection on CTC numbers will be analyzed. 


\section{References}

1. Ruiterkamp J, Ernst MF, de Munck L, van der Heiden-van der Loo M, Bastiaannet E, van de Poll-Franse LV, Bosscha K, Tjan-Heijnen VCG, Voogd AC. Improved survival of patients with primary distant metastatic breast cancer in the period of $1995-2008$. A nationwide population-based study in the Netherlands. Breast Cancer Res Treat. 2011;128:495-503

2. Ly BH, Nguyen NP, Vinh-Hung V, Rapiti E, Vlastos G. Loco-regional treatment in metastatic breast cancer patients: Is there a survival benefit? Breast Cancer Res Treat. 2010;119:537-545

3. Chia SK, Speers CH, D'yachkova Y, Kang A, Malfair-Taylor S, Barnett J, Coldman A, Gelmon KA, O'reilly $\mathrm{SE}$, Olivotto IA. The impact of new chemotherapeutic and hormone agents on survival in a populationbased cohort of women with metastatic breast cancer. Cancer. 2007;110: 973-979

4. Ernst MF, van de Poll-Franse LV, Roukema JA, Coebergh JW, van Gestel CM, Vreugdenhil G, Louwman MJ, Voogd AC. Trends in the prognosis of patients with primary metastatic breast cancer diagnosed between 1975 and 2002. Breast. 2002;16:344-351

5. Khan SA, Stewart AK, Morrow M. Does aggressive local therapy improve survival in metastatic breast cancer? Surgery. 2002;132:620-627

6. Babiera GV, Rao R, Feng L, Meric-Bernstam F, Kuerer HM, Singletary SE, Hunt KK, Ross MI, Gwyn KM, Feig BW, Ames FC, Hortobagyi GN. Effect of primary tumor extirpation in breast cancer patients who present with stage IV disease and an intact primary tumor. Ann Surg Oncol. 2005;13:776-782

7. Rapiti E, Verkooijen HM, Vlastos G, Fioretta G, Neyroud-Caspar I, Sappino AP, Chappuis PO, Bouchardy C. Complete excision of primary breast tumor improves survival of patients with metastatic breast cancer at diagnosis. J Clin Oncol. 2006;24:2743-2749

8. Fields RC, Jeffe DB, Trinkaus K, Zhang $Q$, Arthur C, Aft R, Dietz JR, Eberlein TJ, Gillanders WE, Margenthaler JA. Surgical resection of the primary tumor is associated with increased long-term survival in patients with stage IV breast cancer after controlling for site of metastasis. Ann Surg Oncol. 2007; 14:3345-3351

9. Gnerlich J, Jeffe DB, Deshpande AD, Beers C, Zander C, Margenthaler JA. Surgical removal of the primary tumor increases overall survival in patients with metastatic breast cancer. Analysis of the 1988-2003 SEER data. Ann Surg Oncol. 2007;14:2187-2194

10. Blanchard DK, Shetty PB, Hilsenbeck SG, Elledge RM. Association of surgery with improved survival in stage IV breast cancer patients. Ann Surg. 2008;247:732-738

11. Ruiterkamp J, Ernst MF, van de Poll-Franse LV, Bosscha K, Tjan-Heijnen VC, Voogd AC. Surgical resection of the primary tumour is associated with improved survival in patients with distant metastatic breast cancer at diagnosis. Eur J Surg Oncol. 2009 ;35:1146-1151

12. Neuman HB, Morrogh M, Gonen M, Van Zee KJ, Morrow M, King TA. Stage IV breast cancer in the era of targeted therapy. Does surgery of the primary tumor matter? Cancer. 2010;116:1226-1233

13. Rao R, Feng L, Kuerer HM, Singletary SE, Bedrosian I, Hunt KK, Ross MI, Hortobagyi GN, Feig BW, Ames FC, Babiera GV. Timing of surgical intervention for the intact primary in stage IV breast cancer patients. Ann of Surg Oncol. 2008;15:1696-1702

14. Ruiterkamp J, Voogd AC, Bosscha K, Tjan-Heijnen VCG, Ernst MF. Impact of breast surgery on survival in patients with distant metastases at initial presentation. A systematic review of the literature. Breast Cancer Res Treat. 2010;120:9-16

15. Cady B, Nathan NR, Michaelson JS, Golshan M, Smith BL. Matched pair analyses of stage IV breast cancer with or without resection of primary breast site. Ann Surg Oncol. 2008;15:3384-3395

16. Bafford AC, Burstein HJ, Barkley CR, Smith BL, Lipsitz S, Iglehart JD, Winer EP, Golshan M.: Breast surgery in stage IV breast cancer: impact of staging and patient selection on overall survival. Breast Cancer Res Treat. 2009;115:7-12

17. Leung AM, Vu HN, Nguyen KA, Thacker LR, Bear HD. Effects of surgical excision on survival of patients with stage IV breast cancer. J Surg Res. 2010;161:83-88

18. Dominici L, Najita J, Hughes M, Niland J, Marcom P, Wong Y, Carter B, Javid S, Edge S, Burstein H, Mehra Golshan. Surgery of the primary tumor does not improve survival in stage IV breast cancer. Breast Cancer Res Treat. 2011;129:459-465 
19. Pocock S, Simon R. Sequential treatment assignment with balancing of prognostic factors in controlled clinical trials. Biometrics. 1975;31:103 -115

20. http://www.wma.net/en/30publications/10policies/b3/index.html

21. Haybittle JL. Repeated assessment of results in clinical trials of cancer treatment. $\mathrm{Br} \mathrm{J}$ Radiol. 1971;44:793-797

22. Peto R, Pike MC, Armitage P, Breslow NE, Cox DR, Howard SV, Mantel N, McPherson K, Peto J, Smith $P G$. Design and analysis of randomized clinical trials requiring prolonged observation or each patient. Br J Cancer. 1976;34:585-612 


\section{CHAPTER 7}

THE ROLE OF SURGERY IN BREAST CANCER LIVER AND LUNG METASTASES

J Ruiterkamp MF Ernst 


\section{Abstract}

\section{Objective}

Patients with secondary metastatic breast cancer are treated with systemic therapy, whereas metastasectomy of liver and lung metastases might improves overall survival of these patients. We performed a systematic review of the literature to weigh the evidence for and against metastasectomy. Also treatment of vertebrae en femur metastases and brain metastases is discussed.

\section{Methods}

Eight reports on metastasectomy in hepatic metastases, ten about minimally invasive techniques for liver metastases and nine studies regarding metastasectomy in patients with pulmonary metastases were recently published. These results and conclusions were analyzed and compared.

\section{Results}

All studies were conducted retrospectively. In metastasectomy for liver metastases, median survival ranged from 27 till 63 months, with a 5-year overall survival between 21 and $61 \%$. In case of radiofrequency ablation median survival ranged from 2,5 to 5 years. In patients with lung metastases median survival ranged between 32 and 76 months. Five-year overall survival rates were 31 to 54\%. Low morbidity and mortality numbers were reported. Important factors if considering metastasectomy were; young age, long disease free interval and small number of metastases. Best results are generated if a combination of systemic therapy and surgery can be realized.

\section{Conclusions}

Selected patients could benefit from metastasectomy of liver and lung metastases. When metastasectomy is not possible, minimally invasive techniques can be used in selected patients for the treatment of breast cancer liver metastases. In case of metastases in femur and vertebrae, surgical treatment is used only to prevent or treat pathological fractures or spinal cord compression. Even in brain metastases local treatment, such as surgery, can be considered. 


\section{Introduction}

Secondary metastatic breast cancer is defined as recurrence of disease by distant metastases. In case of breast cancer, sites of metastases are bone (85\%), liver (40-50\%), pleuritis carcinomatosa (20\%) lung (15-25\%) and brain (6-16\%). Median survival of these patients nowadays is 58 months after recurrence, with a 5-year overall survival of $44 \% .{ }^{1}$ Recent results of studies regarding metastasectomy of liver and lung metastases draw attention to this type of extensive treatment and raise questions concerning its effect. Further, because of the serious implications of metastases in the vertebrae and femur, treatment of these types of metastases are also highlighted.

\section{Metastasectomy of breast cancer liver metastases}

A small part (5\%) of all patients with breast cancer develop liver metastases without extrahepatic disease. If treated with chemotherapy, median survival of breast cancer patients with only liver metastases or with limited disease elsewhere is 19 to 26 months. ${ }^{2}$

\section{Review of literature}

Eight reports on metastasectomy in hepatic metastases from breast cancer are published in the last 10 years (Table 7.1). ${ }^{3-11}$ All were single institution studies with 17 to 85 patients, treated between 1986 and 2004. All patients received metastasectomy of hepatic metastases. Median survival ranged from 27 till 63 months, with a 5-year overall survival between 21 and 61\%. No control groups were available, except for 2 studies, which compared complete resection with irradical resection.,10 In case of R0 (complete macroscopic and microscopic) resection, 5-year survival was 43\%, compared to $42 \%$ in R1 (microscopic residual disease) resection and $10 \%$ in $\mathrm{R} 2$ (macroscopic residual disease) resection, described in the study of Adam et al. ${ }^{10}$ In the study of Elias et al. the completeness of the resection did not appear to be of significant prognostic value. ${ }^{7}$ Reported proportion of complete resections ranged from $65 \%$ to $86 \%$. $^{2,7,10}$

Postoperative mortality was very low, in none of the studies surgical related deaths were described (Table 7.2). Overall or postoperative morbidity occurred - in case it was reported - in 0 to $22 \%$ of all patients. Recurrence of disease in liver and/or at other sites occurred in 52 to $76 \%$ of all patients. In 13 to $56 \%$ of all cases the first place of recurrence was in the remaining liver. 


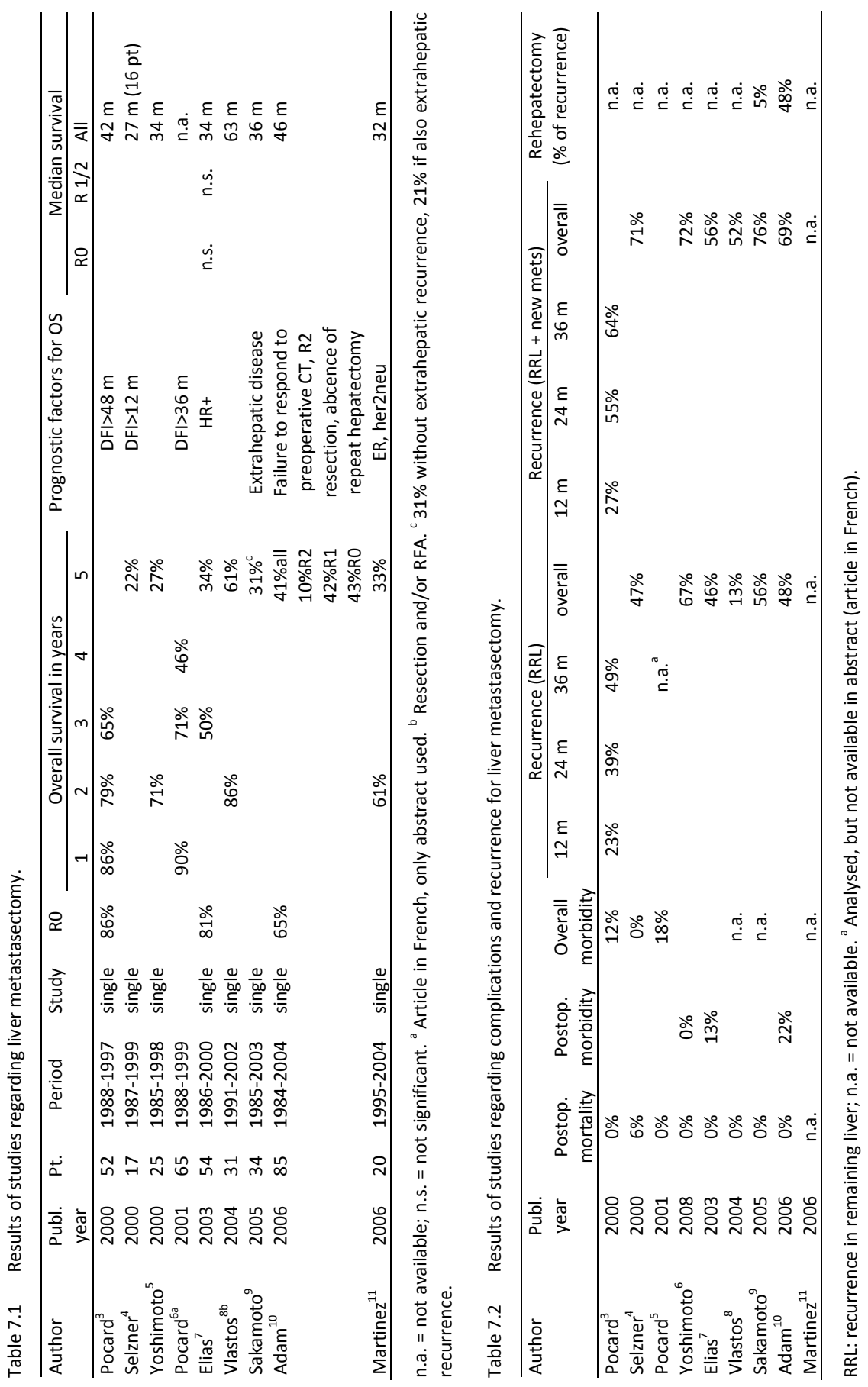


Only 2 studies describe the number of patients who received a rehepatectomy for recurrent metastases; Sakamoto et al. reoperated 5\% (1) of the patients who had hepatic recurrence, but Adam et al. described at least 1 rehepatectomy in almost half of the patients with recurrent disease in the liver. ${ }^{9,10}$ Patients who had at least 1 repeated hepatic resection, had a higher 5 -year overall survival $(81 \%)$ compared to patients with unresectable liver recurrences and patients without any hepatic recurrence following the first hepatic resection (5-year overall survival of 29\%) according to the results of Adam et al. ${ }^{10}$

Prognostic factors influencing overall survival were disease free interval (DFI), hormone positive tumor, extrahepatic disease, failure to respond to chemotherapy and $\mathrm{R} 2$ resection.

Retrospective analyses, small numbers of patients, relative long study intervals, use of different outcome parameters and the absence of control groups to compare results, make it difficult to draw conclusions. All studies enclosed only patients selected for surgery, thereby causing bias. Also, information about the timing of metastasectomy is missing. Nevertheless, median survival for patients treated with hepatic metastasectomy is higher compared to patients who did not have surgery. Further, there are no reports of serious surgical related incidents.

\section{Recommendations}

Metastasectomy for liver metastases in patients with colorectal cancer is accepted nowadays. ${ }^{12}$ Based on the above results, some indications for hepatic metastasectomy in breast cancer patients could be given. Liver surgery is beneficial for selected patients: (1) young(er) patients, (2) low operation risk, (3) long interval (more than one year) between breast cancer surgery and liver metastases, (4) positive hormone receptor status of primary tumor, (5) no extrahepatic disease (except bone metastases), (6) less than four metastases, (7) demonstrated disease regression or stability with systemic therapy (chemotherapy or hormonal treatment) before resection, (8) normal liver function tests, (9) resection with intent of a complete (R0 resection) of liver metastases. Based on the little information about rehepatectomy in case of recurrence of disease in the remaining liver after initial liver metastasectomy, one could argue that this might be a valuable treatment to prolong survival.

\section{Minimally invasive techniques as treatment of breast cancer liver metastases}

\section{Introduction}

When surgical resection of liver metastases is not possible, due to for instance the location of the tumors, multifocality and/or an insufficient liver reserve, several 
minimally invasive techniques have been developed to produce localized intrahepatic tumor destruction, including radiofrequency ablation (RFA), laser-induced thermotherapy (LITT) and microwave.

\section{Review of literature}

Six reports on the treatment of breast cancer liver metastases with radiofrequency ablation have been published so far (Table 7.3). ${ }^{13-18}$ Most were single institution studies with 12-52 patients, treated between 1996 and 2008. Median survival was not specified in three studies en ranged from 2,5 to 5,0 years in the remaining three. No control groups were available. In none of the studies procedure related deaths were described. Pleural effusion and subcapsular hematoma of the liver were the most common side effects, but rarely needed treatment (Table 7.4).

The three studies on the treatment of breast cancer liver metastases with laserinduced thermotherapy were reported by one study group from Frankfurt, Germany. ${ }^{19-21}$ In 2004 Mack et al. described their results after treating 578 lesions in 232 patients. The five year overall survival rate and mean survival were $41 \%$ and 4,9 years respectively and there was a low complication rate. Vogl et al. presented their results in 2010, describing 161 patients who were treated with transarterial chemoembolization (TACE) to achieve the size and number of metastatic lesions that met the requirements for LITT. The complication rate was higher than in their previous study and five year overall survival rate and mean survival lower: $14 \%$ and 2,7 years.

Only one study describing the effect of microwave thermocoagulation on breast cancer liver metastases has been published. ${ }^{22}$ Eleven nodules in 8 patients were treated with a technical success rate of $91 \%$. Unfortunately overall survival rates and median survival are not mentioned. After a mean observation period of 25,9 months $62,5 \%$ of the patients are alive with new metastatic foci. 


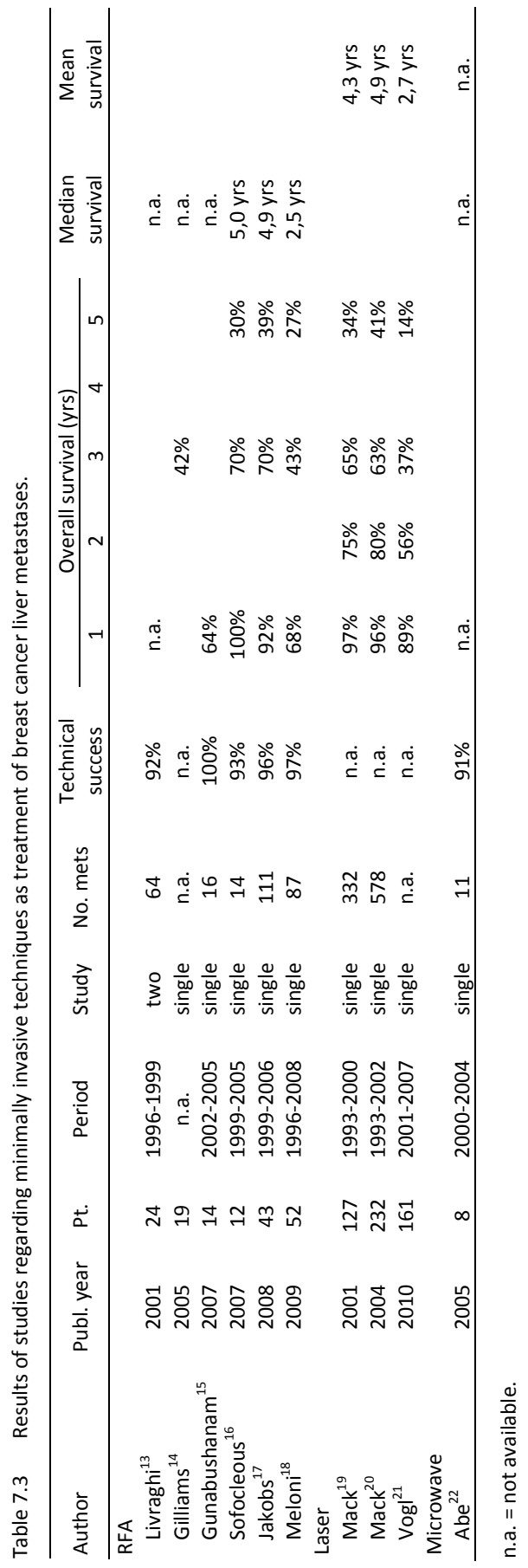


Table 7.4 Results of studies regarding complications in minimally invasive techniques.

\begin{tabular}{|c|c|c|}
\hline Author & Publ. year & Complications \\
\hline \multirow[t]{2}{*}{ Livraghi $^{13}$} & 2001 & perirenal hematoma (4\%) \\
\hline & & pain due to diaphragmatic thickening (4\%) \\
\hline Gilliams $^{14}$ & 2005 & n.a. \\
\hline \multirow[t]{2}{*}{ Gunabushanam $^{15}$} & 2007 & pleural effusion (14\%) \\
\hline & & peri-hepatic fluid collection (7\%) \\
\hline \multirow[t]{2}{*}{ Sofocleous ${ }^{16}$} & 2007 & prolonged shoulder pain (8\%) \\
\hline & & pleural effusion (8\%) \\
\hline \multirow[t]{5}{*}{ Jakobs $^{17}$} & 2008 & subcapsular hematoma $(4,6 \%)$ \\
\hline & & hematoma of the abdominal wall $(2,3 \%)$ \\
\hline & & pleural effusion $(11,6)$ \\
\hline & & severe intrahepatic bleeding $(4,6 \%)$ \\
\hline & & bile duct injury $(2,3 \%)$ \\
\hline \multirow[t]{3}{*}{ Meloni $^{18}$} & 2009 & perirenal hematoma ( $2 \%)$ \\
\hline & & biloma (2\%) \\
\hline & & pleural effusion (10\%) \\
\hline Mack $^{19}$ & 2001 & n.a. \\
\hline \multirow[t]{5}{*}{ Mack $^{20}$} & 2004 & pleural effusion $(0,9 \%)$ \\
\hline & & liver abscess $(0,4 \%)$ \\
\hline & & injury to bile duct $(0,2 \%)$ \\
\hline & & subcapsular hematoma $(4,4 \%)$ \\
\hline & & non-symptomatic pleural effusion $(9,1 \%)$ \\
\hline \multirow[t]{5}{*}{$\operatorname{Vog}^{21}$} & 2010 & chemotherapy-associated steatohepatitis $(7,5 \%)$ \\
\hline & & reactive pleural effusion $(35,4 \%)$ \\
\hline & & biloma $(9,3 \%)$ \\
\hline & & subcapsular hematoma $(6,8 \%)$ \\
\hline & & basal lung atelectasis $(10,6 \%)$ \\
\hline $\mathrm{Abe}^{22}$ & 2005 & high fever e.c.i. (9\%) \\
\hline
\end{tabular}

n.a. = not available.

\section{Discussion}

Minimally invasive treatment of breast cancer liver metastases can be performed in selected patients. Similar with surgical resection, studies on this subject are retrospective and lack control groups. There are no randomized controlled trials conducted. When metastasectomy is not possible because of the location of the tumors, multifocality and/or an insufficient liver reserve, minimally invasive techniques can be considered as an alternative treatment. The technique that has been studied most is radiofrequency ablation. 


\section{Metastasectomy of breast cancer lung metastases}

A solitary pulmonary nodule in patients with (a history of) breast cancer appears to be a metastasis of the breast in $33-40 \%$ of all cases. Only $3 \%$ of all breast cancer patients develop such a solitary lesion. ${ }^{2}$ In general, median survival in case of isolated pulmonary metastases (due to breast cancer) is 13 to 25 months, but there are very few reports on this subject. ${ }^{23}$

\section{Review of literature}

In recent years, 9 studies regarding metastasectomy in patients with pulmonary metastases were published (Table 7.5). ${ }^{23-31}$ Most studies contained 15 to 47 patients, but three were larger; they included 90, 125 and 467 patients. ${ }^{23,25,28}$ All patients were treated in the period between 1960 and 2007 and most were single institution studies, except the study of Friedel et al., which was based on results of the International Registry of Lung Metastases. ${ }^{23}$ Generally, all studies reported 5-year overall survival rates, ranging from 31 to 54\%, except for the study of Yhim et al., who described a 4 -year overall survival of $82 \%$ for patients with less than 4 metastases. ${ }^{31}$ Reported 10-year overall survival ranged from 18 to $40 \%$ in five studies. Median survival, reported in half of the studies, ranged between 32 and 76 months. Friedel et al. made a distinction between median survival in patients with a RO and R1/2 resection, which was 37 and 25 months, respectively. ${ }^{23}$ The percentage of patients who were treated with a complete resection varied from 57 to $100 \%$.

Postoperative mortality, described in five of all studies, was low, and occurred in $0-1 \%$ of all cases (Table 7.6). Only Planchard et al. informed about the amount of postoperative morbidity, which took place in $13 \%$ of all patients. ${ }^{25}$ Recurrence of lung metastases was recorded in 3 studies and ranged from 13 to $28 \%$. Recurrence of disease (lung metastases and/or other locations) was approximately 68\%. Reoperation for recurrent lung metastases was only described by Friedel et al. and was performed in $4 \%$ of all patients who had lung recurrence. The 5-year survival of these patients was $53 \%$, suggesting a benefit from redo surgery. ${ }^{23}$

Prognostic factors in favour of prolonged survival were disease free interval (DFI) >36 months, hormone receptor positive breast cancer, stage I breast cancer, small size of largest metastasis and less than 4 metastatic sites. In the only study that compared metastasectomy to systemic therapy, surgery was a independent prognostic factor for progression free survival, but not for overall survival. ${ }^{31}$

All studies were retrospectively analysed and only one study compared patients who received metastasectomy with patients treated with systemic therapy only. Most studies were small, single institution studies and only one study was registry based. ${ }^{23}$ Conform the studies regarding hepatic metastasectomy, study periods were relatively long. Median survival after metastasectomy in general was quite reasonable. 

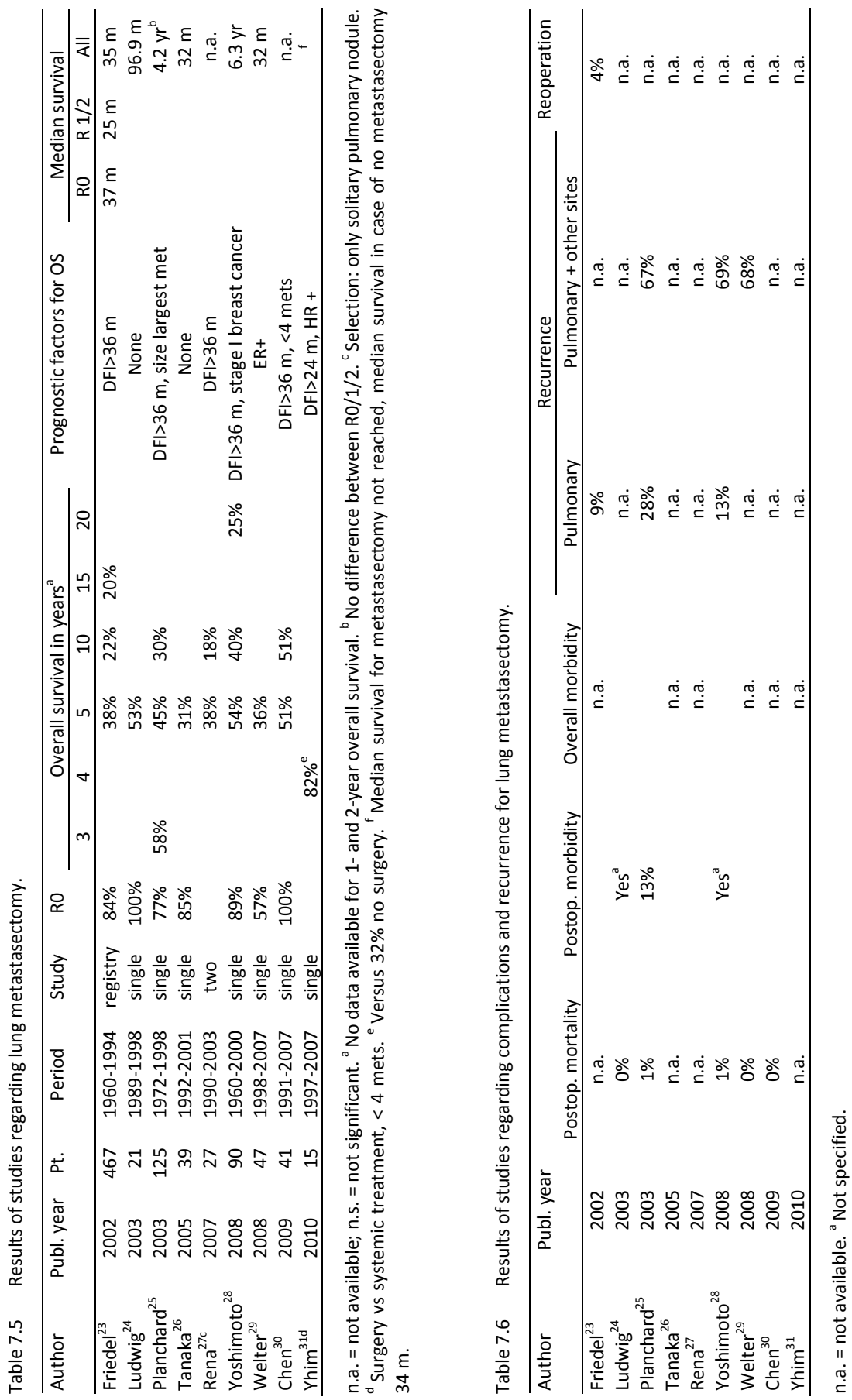


\section{Recommendations}

First, metastasectomy in lung metastases is an important diagnostic tool, allowing for differential diagnosis, like primary lung cancers and benign lesions. ${ }^{2,12}$ Second, this potentially beneficial procedure can be discussed in a selected group of patients, to prolong survival. ${ }^{12}$ Apart from the general indications, like performance status and age, for metastasectomy in patients with lung metastases that are also described in the paragraph about liver metastases, DFI is also important in case of lung metastases. Though, in lung metastases, a DFI more than 36 months (instead of 1 year as in liver metastases) is an indication for metastasectomy. Further, a complete (R0) resection should be possible and lung metastases should be of small volume. With regard to surgical procedure, there were no significant differences between the type of resection. ${ }^{23}$ In case of a solitary pulmonary nodule, video-assisted thoracoscopic surgery (VATS) is a good procedure for diagnostic management, when breast cancer metastases are diagnosed, an open procedure must be performed to palpate the entire lung to exclude previously unknown nodules. ${ }^{27}$

\section{Discussion}

Metastasectomy in case of liver - or lung metastases of breast cancer can be performed in selected patients. Studies about this subject are retrospective and lack control groups. There are no randomized controlled trials conducted. Further, no research has been done about the right timing for metastasectomy, therefore, no good advice about this subject can be given. It is generally accepted that in all cases systemic therapy should be administered. Metastasectomy can be an adjuvant treatment, but when distant metastases have occurred, the disease should be considered and approached as a systemic problem. Best results are generated if a combination of systemic therapy and surgery can be realized.

\section{Treatment of breast cancer metastases in the vertebrae and femur}

In patients with breast cancer who develop bone metastases, these metastases occur mostly in long bones and the spine. Most common indications for surgery in these cases are complete fracture, impending fracture and spinal neurologic deficit or pain. $^{32}$ In case of painful bone metastases radiotherapy is an effective treatment. Most patients experience a significant reduction of the pain and in $33-50 \%$ of all patients the pain disappears completely. ${ }^{33,34}$ In large, osteolytic lesions with (the risk of) a pathological fracture or in metastases in the vertebrae with (the risk of) spinal cord compression, surgical stabilisation in combination with postoperative radiotherapy is advised. The latter is recommended to prevent luxation of the 
osteosynthesis. ${ }^{35}$ Especially in case of spinal cord compression patients should receive treatment as soon as possible. Neurosurgical and/or orthopaedic surgery followed by radiotherapy causes improved recovery of function compared to radiotherapy alone. ${ }^{36}$ The primary goal of surgery in these patients is prevent or delay pathological factures or spinal cord compression, so bone lesion progression should be monitored closely. Patients with large osteolytic lesions on weight-bearing areas should receive surgical stabilisation. If pathological fracture has occurred, surgery may stabilize bones, and may facilitate healing. ${ }^{37}$ A population-based study on the surgical treatment for skeletal breast cancer metastases showed that after surgery, pain decreased in $77 \%$ of all patients and function improved in $65 \%(n=107)$. Approximately $10 \%$ of the patients underwent a reoperation, in which experience in treating pathological fractures seems to play a role. In case of proximal femur fractures, less complications were seen in endoprosthetic replacement compared to osteosynthetic devices. ${ }^{32}$ In patients who received spinal surgery $(n=87)$, pain was reduced significantly postoperative (reduction of pain level measured by visual analog scale (VAS) from 6 to 2 ) and $75 \%$ of the patients who were nonambulatory regained ambulation. $26 \%$ of all patients who received surgery had major complications, which is in line with other studies. ${ }^{38}$

\section{Treatment of breast cancer metastases in the brain}

A very small amount of patients with metastatic breast cancer have a solitary brain metastasis. Surgery of the solitary metastasis in combination with postoperative radiotherapy can be considered, and this intensive treatment can lead to a significant improvement in survival. ${ }^{39}$ Stereotactic radiotherapy can be a good alternative for surgery. ${ }^{40,41}$ The largest retrospective study on surgery of brain metastases illustrated that craniotomy followed by whole-brain radiotherapy (WBRT) can positively impact survival. Overall median survival in patients who received craniotomy $(n=70)$ was 16.2 months after diagnosis of the brain tumor. There was no statistical difference in survival for patients who had single or multiple lesions. In multivariate analysis, adjuvant WBRT after craniotomy and the absence of meningeal carcinomatosis were the only significant predictive variables for longer survival. The frequency of complications after surgery are not described. It is recommended that patients with a single metastasis or two or even three accessible metastases from breast cancer be considered for local treatment, such as surgery. ${ }^{42}$ 


\section{References}

1. Giordano SH, Buzdar AU, Smith TL, Kau SW, Yang Y, Hortobagyi GN. Is breast cancer survival improving? Trends in survival for patients with recurrence breast cancer diagnosed form 1974 through 2000. Cancer. 2004;100:44-52

2. Singletary SE, Walsh G, Vauthey JN, Curley S, Sawaya R, Weber KL, Meric F, Hortobágyi GN. A role for curative surgery in the treatment of selected patients with metastatic breast cancer. Oncologist. 2003;8:241-251

3. Pocard M, Pouillart P, Asselain B, Salmon RJ. Hepatic resection in metastatic breast cancer: results and prognostic factors. Eur J Surg Onol. 2000;26:155-159

4. Selzner M, Morse MA, Vredenburgh JJ, Meyers WC, Clavien PA. Liver metastases form breast cancer: Long-term survival after curative resection. Surgery. 2000;127:383-389

5. Yoshimoto M, Tada T, Saito M, Takahashi K, Uchida $Y$, Kasumi F. Surgical treatment of hepatic metastases from breast cancer. Breast Cancer Res Treat. 2000;59:177-184

6. Pocard M, Pouillart P, Asselain B, Falcou MC, Salmon RJ. [Hepatic resection for breast cancer metastases: results and prognosis (65 cases)] [Article in French] Ann Chir. 2001;126:413-420

7. Elias D, Maisonnette F, Druet-Cabanac M, Ouellet JF, Guinebretiere JM, Spielmann M, Delaloge S.An attempt to clarify indications for hepatectomy for liver metastases from breast cancer. Am J Surg. 2003;185:158-164

8. Vlastos G, Smith DL, Singletary SE, Mirza NQ, Tuttle TM, Popat RJ, Curley SA, Ellis LM, Roh MS, Vauthey $\mathrm{JN}$. Long-term survival after an aggressive surgical approach in patients with breast cancer hepatic metastases. Ann Surg Oncol. 2004;11:869-874

9. Sakamoto Y, Yamamoto J, Yoshimoto M, Kasumi F, Kosuge T, Kokudo N, Makuuchi M. Hepatic resection for metastatic breast cancer: prognostic analysis of 34 patients. World J Surg. 2005;29:524527

10. Adam R, Aloia T, Krissat J, Bralet MP, Paule B, Giacchetti S, Delvart V, Azoulay D, Bismuth H, Castaing D. Is liver resection justified for patients with hepatic metastases from breast cancer? Ann Surg. 2006;244:897-907

11. Martinez SR, Young SE, Giuliano AE, Bilchik AJ. The utility of estrogen receptor, progesterone receptor, and Her-2/neu status to predict survival in patients undergoing hepatic resection for breast cancer metastases. Am J Surg. 2006;191:281-283

12. Pagani O, Senkus E, Wood W, Colleoni M, Cufer T, Kyriakides S, Costa A, Winer EP, Cardoso F; ESO$\mathrm{MBC}$ Task Force. International guidelines for management of metastatic breast cancer: can metastatic breast cancer be cured? J Natl Cancer Inst. 2010;102:456-463

13. Livraghi T, Goldberg SN, Solbiati L, Meloni F, lerace T, Gazelle GS. Percutaneous radio-frequency ablation of liver metastases from breast cancer: initial experience in 24 patients. Radiology. 2001;220:145-149

14. Gillams AR. The use of radiofrequency in cancer. Br J Cancer. 2005;92:1825-1829

15. Gunabushanam G, Sharma S, Thulkar S, Srivastava DN, Rath GK, Julka PK, Bhatnagar S. Radiofrequency ablation of liver metastases from breast cancer: results in 14 patients. J Vasc Interv Radiol. 2007;18:67-72

16. Sofocleous CT, Nascimento RG, Gonen M, Theodoulou M, Covey AM, Brody LA, Solomon SM, Thornton $\mathrm{R}$, Fong $\mathrm{Y}$, Getrajdman GI, Brown KT. Radiofrequency ablation in the management of liver metastases from breast cancer. AJR Am J Roentgenol. 2007;189:883-889

17. Jakobs TF, Hoffmann RT, Schrader A, Stemmler HJ, Trumm C, Lubienski A, Murthy R, Helmberger TK, Reiser MF. CT-guided radiofrequency ablation in patients with hepatic metastases from breast cancer. Cardiovasc Intervent Radiol. 2009;32:38-46

18. Meloni MF, Andreano A, Laeseke PF, Livraghi T, Sironi S, Lee FT Jr. Breast cancer liver metastases: USguided percutaneous radiofrequency ablation -intermediate and long-term survival rates. Radiology. 2009;253:861-869

19. Mack MG, Straub R, Eichler K, Engelmann K, Zangos S, Roggan A, Woitaschek D, Böttger M, Vogl TJ. Percutaneous MR imaging-guided laser-induced thermotherapy of hepatic metastases. Abdom Imaging. 2001;26:369-374 
20. Mack MG, Straub R, Eichler K, Söllner O, Lehnert T, Vogl TJ. Breast cancer metastases in liver: laserinduced interstitial thermotherapy - local tumor control rate and survival data. Radiology. 2004;233:400-409

21. Vogl TJ, Naguib NN, Nour-Eldin NE, Mack MG, Zangos S, Abskharon JE, Jost A. Repeated chemoembolization followed by laser-induced thermotherapy for liver metastasis of breast cancer. AJR Am J Roentgenol. 2011;196:W66-72

22. Abe H, Kurumi Y, Naka S, Shiomi H, Umeda T, Naitoh H, Endo Y, Hanasawa K, Morikawa S, Tani T. Open-configuration MR-guided microwave thermocoagulation therapy for metastatic liver tumors from breast cancer. Breast Cancer. 2005;12:26-31

23. Friedel G, Pastorino U, Ginsberg RJ, Goldstraw P, Johnston M, Pass H, Putnam JB, Toomes H; International Registry of Lung Metastases, London, England. Results of lung metastasectomy from breast cancer: prognostic criteria on the basis of 467 cases of thelinternational Registry of Lung Metastases. Eur J Cardiothorac Surg. 2002;22:335-344

24. Ludwig C, Stoelben E, Hasse J. Disease-free survival after resection of lung metastases in patients with breast cancer. Eur J Surg Oncol. 2003;29:532-535

25. Planchard D, Soria JC, Michiels S, Grunenwald D, Validire P, Caliandro R, Girard P, Le Chevalier T. Uncertain benefit from surgery in patients with lung metastases from breast carcinoma. Cancer. 2004;100:28-35

26. Tanaka F, Li M, Hanaoka N, Bando T, Fukuse T, Hasegawa S, Wada H. Surgery for pulmonary nodules in breast cancer patients. Ann Thorac Surg. 2005;79:1711-1715

27. Rena O, Papalia E, Ruffini E, Filosso PL, Oliaro A, Maggi G, Casadio C. The role of surgery in the management of solitary pulmonary nodule in breast cancer patients. Eur J Surg Oncol. 2007;33:546550

28. Yoshimoto M, Tada K, Nishimura S, Makita M, Iwase T, Kasumi F, Okumura S, Sato Y, Nakagawa K. Favourable long-term results after surgical removal of lung metastases of breast cancer. Breast Cancer Res Treat. 2008;110:485-491

29. Welter S, Jacobs J, Krbek T, Tötsch M, Stamatis G. Pulmonary metastases of breast cancer. When is resection indicated? Eur J Cardiothorac Surg. 2008;34:1228-1234

30. Chen F, Fujinaga T, Sato K, Sonobe M, Shoji T, Sakai H, Miyahara R, Bando T, Okubo K, Hirata T, Toi M, Date $\mathrm{H}$. Clinical features of surgical resection for pulmonary metastasis from breast cancer. Eur J Surg Oncol. 2009;35:393-397.

31. Yhim HY, Han SW, Oh DY, Han W, Im SA, Kim TY, Kim YT, Noh DY, Chie EK, Ha SW, Park IA, Bang YJ. Prognostic factors for recurrent breast cancer patients with an isolated, limited number of lung metastases and implications for pulmonary metastasectomy. Cancer. 2010;116:2890-2901

32. Wedin R, Bauer HCF, Rutqvist L. Surgical treatment for skeletal breast cancer metastases. Cancer. 2001;92:257-262

33. Agarawal JP, Swangsilpa T, van der Linden $Y$, Rades D, Jeremic B, Hoskin PJ. The role of external beam radiotherapy in the management of bone metastases. Clin Oncol (R Coll Radiol). 2006;18:747-760

34. van der Linden YM, Lok JJ, Steenland E, Martijn H, van Houwelingen H, Marijnen CA, Leer JW; Dutch Bone Metastasis Study Group. Single fraction radiotherapy is efficacious: a further analysis of the Dutch Bone Metastasis Study controlling for the influence of retreatment. Int J Radiat Oncol Biol Phys. 2004;59:528-537

35. Townsend PW, Smalley SR, Cozad SC, Rosenthal HG, Hassanein RE. Role of postoperative radiation therapy after stabilization of fractures caused by metastatic disease. Int J Radiat Oncol Biol Phys. 1995;31:43-49

36. Patchell RA, Tibbs PA, Regine WF, Payne R, Saris S, Kryscio RJ, Mohiuddin M, Young B Direct decompressive surgical resection in the treatment of spinal cord compression caused by metastatic cancer: a randomised trial. Lancet. 2005;366:643-648

37. Lipton A. Management of bone metastases in breast cancer. Curr Treat Options Oncol. 2005;6: 161-171

38. Shehadi JA, Sciubba DM, Suk I, Suki D, Maldaun MV, McCutcheon IE, Nader R, Theriault R, Rhines LD, Gokaslan ZL. Surgical treatment strategies and outcome in patients with breast cancer metastatic to the spine: a review of 87 patients. Eur Spine J. 2007;16:1179-1192 
39. Tsao MN, Lloyd NS, Wong RK, Rakovitch E, Chow E, Laperriere N; Supportive Care Guidelines Group of Cancer Care Ontario's Program in Evidence-based Care. Radiotherapeutic management of brain metastases: a systematic review and meta-analysis. Cancer Treat Rev. 2005;31:256-273

40. Akyurek S, Chang EL, Mahajan A, Hassenbusch SJ, Allen PK. Stereotactic radiosurgical treatment of cerebral metastases arising from breast cancer. Am J Clin Oncol. 2007;30:310-314

41. Rades D, Bohlen G, Pluemer A, Veninga T, Hanssens P, Dunst J, Schild SE. Stereotactic radiosurgery alone versus resection plus whole-brain radiotherapy for 1 or 2 brain metastases in recursive partitioning analysis class 1 and 2 patients. Cancer. 2007;109:2515-2521

42. Wronski M, Arbit E, McCormick B. Surgical treatment of 70 patients with brain metastases from breast carcinoma. Cancer. 1997;80:1746-1754 


\section{CHAPTER 8}

SUMMARY, CONCLUSIONS AND FUTURE PERSPECTIVES 


\section{Summary}

Approximately $5 \%$ of all patients with invasive breast cancer have distant metastatic disease at initial presentation. This is called primary metastatic breast cancer. Currently, the standard of care for the treatment of patients with primary metastatic breast cancer does not include surgery of the breast tumor. However, during the last 10 years a substantial number of observational studies have been published, in which the removal of the primary tumor in this patient group was associated with a survival benefit. This observation was studied and described into further detail in this thesis. Additionally, the possible benefit of surgery of breast cancer metastases in patients with secondary metastatic breast cancer was reviewed, especially in liver and lung metastases. In these patients the metastases develop in the years after the diagnosis and treatment of the breast tumor.

In Chapter $\mathbf{2}$ changes in prognosis of more than 8000 patients with primary distant metastatic breast cancer were analyzed, using data of the Netherlands Cancer Registry. Patients were divided into three periods, based on the year of diagnosis of their disease, to analyze if an improvement in prognosis had occurred.

The median survival of patients with primary metastatic disease improved from 1.42 to 1.95 years between 1995 and 2008. This improvement was most pronounced for patients below the age of 50 . Patients receiving systemic treatment, locoregional radiotherapy or breast surgery had a significantly lower risk of death compared to patients not receiving these treatment options.

The increased efficacy of chemotherapy and the introduction of targeted treatments are considered to be the most likely explanations for the improved median survival. This assumption is supported by the fact that the survival benefit was larger for younger patients, who were also more likely to receive targeted treatments.

The results of a population-based study in which the impact of a surgical resection of the primary tumor on survival in patients with primary distant metastatic breast cancer was investigated were presented in chapter 3. For this study, population-based data of the Eindhoven Cancer Registry were used. Seven-hundred-and-twenty-eight patients with distant metastatic disease at initial presentation were included, diagnosed in the South of the Netherlands between 1993 and 2004. Of these patients, 288 were treated with surgery of the primary tumor (40\%). The proportion of patients who had surgery decreased from 55\% in the period 1993-1996, to $39 \%$ in the period $1997-2000$ and to $30 \%$ in the period 2001-2004 $(P<0.0001)$.

Median survival of patients who had surgery of the primary tumor was significantly longer than for patients who did not have surgery (31 vs. 14 months). The 5-year survival rates were $24.5 \%$ and $13.1 \%$, respectively $(P<0.0001)$. In a multivariable Cox regression analysis, adjusting for age, period of diagnosis, T-classification, number of 
metastatic sites, comorbidity, use of locoregional radiotherapy and use of systemic therapy, surgery appeared to be an independent prognostic factor for overall survival, with a hazard ratio of $0.62(95 \% \mathrm{Cl} 0.56-0.71)$. Patients undergoing axillary dissection tended to have a better overall survival than those without axillary dissection, but this difference was restricted to the first year after treatment. Unfortunately, no information on margin status after surgery was available.

The conclusion based on the above results is that removal of the primary tumor in patients with primary distant metastatic disease is associated with a reduction of the mortality risk of $40 \%$. These results are in line with previous observational studies and provide additional evidence in favour of surgery.

The results described in chapter 3 generated additional questions, especially regarding the role of confounding factors and the impact of the completeness of the surgical removal of the primary tumor. Therefore, the effect of the presence of symptoms of metastases and the timing of surgery, both potential confounders of the impact of surgery, were examined in chapter 4 , as well as the effect of margin status on survival in patients treated with surgery. To determine the impact of these potential confounders, individual charts of 279 patients with primary metastatic breast cancer were reviewed.

Eighty-four of the 279 patients (30\%) underwent surgery of the breast tumor as part of their treatment. The median survival in these patients was 39 months, compared to 15 months for those without surgery $(P<0.0001)$. Patients undergoing surgery were less likely to have metastases at more than one site.

Patients presenting with symptomatic metastatic disease $(n=112)$ were more likely to have cutaneous metastases and metastases of the central nervous system. Further, they were more likely to have three or more metastatic sites. Regarding surgery, fewer patients had a breast operation compared with patients without symptomatic disease. The median survival of patients with symptomatic metastatic disease was 19 months, compared to 22 months for those without symptomatic disease ( $P=0.15)$.

Patients who underwent surgery of the primary tumor before metastatic disease was diagnosed $(n=43)$ had significantly smaller tumors, were less likely to have hormone receptor positive tumors, were less likely to have bone metastases and less likely to have symptomatic metastases at diagnosis. Patients who received surgery and whose metastases were already detected before surgery of the breast tumor had taken place, had a median survival of 38 months, compared to 40 months for patients in whom the metastatic disease was diagnosed after surgery $(P=0.81)$.

The median survival of patients with a complete resection was 41 months, compared to 28 months for those with tumor-positive surgical margins $(P=0.06)$.

In conclusion, the presence of symptomatic metastatic disease is not a significant prognostic factor for patients with distant metastasis at diagnosis, neither is the timing of surgery. Based on these results, it seems unlikely that the prolonged survival 
after surgery can be explained by these potentials confounders. Additionally, patients who had a complete resection of the tumor tend to have a better survival than patients with positive tumor margins.

In recent years, ten retrospective studies on the effect of surgery of the breast tumor in patients with primary metastatic breast cancer on survival were published. These studies were discussed and analysed in chapter $\mathbf{5}$ to provide more understanding in the evidence for and against breast surgery and its effect on survival.

A crude analysis, without adjustment for potential confounders, showed that surgical removal of the breast lesion in primary metastatic disease was associated with a significantly higher overall survival rate in seven of the ten studies and a trend towards a better survival in the three remaining studies. Surgery of the primary tumor appeared to be an independent factor for an improved survival in the multivariate analyses from the individual studies, with hazard ratios ranging from 0.47 to 0.71 . The pooled hazard ratio for overall mortality was $0.65(95 \% \mathrm{Cl} 0.59-0.72)$ in favour of the patients who were treated with surgery. Of the two studies that took into account the surgical margins, one showed that the better survival was only observed in the patients whose primary breast tumor had been removed with free surgical margins, whereas the other study showed that the survival benefit was more pronounced in patients with a complete resection.

Three out of ten studies concluded that surgery was not related to an improved survival and the observed benefit was confounded by stage migration bias, selection bias and coding errors.

Besides surgery, there were several other factors contributing to a better overall survival, like younger age, smaller primary tumor and only one metastatic site. In most of the studies included in the systematic review these factors were taken into account by including them in the multivariate analyses. However, in non-randomized studies there is always a risk of confounding by indication, which means that the association could have been biased by other prognostic factors which correlate with the use of surgery but which have not been measured or are not yet known.

This literature review indicates that surgery of the primary breast tumor has a positive impact on the survival of patients with metastatic disease at initial presentation. Furthermore, in order to provide a definite answer on whether local tumor control in patients with primary metastatic disease improves survival, a randomized controlled trial comparing systemic therapy with or without breast surgery is needed.

The SUBMIT-trial is a randomized clinical trial, designed to overcome the influence of potential biases from which all observational studies may have suffered. In chapter 6, the protocol of the SUBMIT-trial was presented. SUBMIT is an acronym for "Systemic therapy with or without Up front surgery of the primary tumor in Breast cancer patients with distant Metastases at Initial presenTation". This trial will be performed 
to evaluate whether breast surgery in patients with primary distant metastatic breast cancer will improve prognosis. Further, it will be analyzed if up front surgery increases local tumor control (compared to systemic therapy alone). Also, quality of life will be assessed. Approximately 500 patients will either be randomized for up front surgery of the breast tumor followed by systemic therapy, or for systemic therapy followed by delayed local treatment of the breast tumor if indicated.

Patients who are randomized for up front surgery of the breast tumor will receive a lumpectomy or mastectomy depending on patient and tumor characteristics. Both types of surgery may be conducted as long as the intention is a complete resection of the primary tumor. The choice to perform an axillary lymph node dissection is left to the discretion of the treating physician, but is highly recommended if palpable and/or tumor positive lymph nodes in the axillary region are present. If patients are randomized for systemic therapy, breast surgery in case of local progression is allowed to gain local control. There are two situations where radiotherapy to the breast or chest wall should be considered. First, following an incomplete lumpectomy or mastectomy. Second, in case of local progression in patients treated with systemic therapy where non invasive local therapy with radiotherapy is a treatment option instead of surgery. In case of clinically positive axillary lymph nodes, radiotherapy may be a viable treatment option instead of surgery as well. All patients will be treated with systemic therapy according to the guidelines from the National Breast cancer Organization of the Netherlands (NABON) for treatment of breast cancer.

The primary endpoint of this trial is 2-year survival. Quality of life and local tumor control are the most important secondary endpoints.

An overview based on a systematic review on the results of metastasectomy of liver and lung metastases in breast cancer on survival was given in chapter 7 .

A small part of all patients with breast cancer develop liver metastases without extrahepatic disease. If treated with chemotherapy, median survival of these patients is 19 to 26 months. Studies on metastasectomy for liver metastases generally reported better survival rates than studies without surgery, with median survival rates ranging from 27 to 63 months and 5-year overall survival rates varying between 21 and $61 \%$. In the studies on radiofrequency ablation the median survival ranged from 2.5 to 5 years.

In general, median survival in case of isolated pulmonary metastases due to breast cancer is 13 to 25 months. In studies on treatment with metastasectomy of lung metastases the median survival rates tended to be better than in studies without surgery, with figures ranging between 32 and 76 months. Reported 5-year overall survival rates varied between 31 and $54 \%$.

The studies on surgery of liver and lung metastases reported low risks of surgeryrelated morbidity and mortality. Important factors that were mentioned when considering metastasectomy were: young age, long disease free interval and small 
number of metastases. The best results appeared to have been achieved with a combination of systemic therapy and surgery. It was generally accepted that in all cases systemic therapy should be administered. In metastases in the femur and vertebrae, surgical treatment was only used to prevent or treat pathological fractures or spinal cord compression.

We conclude that metastasectomy can be performed in selected patients with liver or lung metastases of breast cancer, in an attempt to improve survival. The use of minimally invasive techniques to remove breast cancer liver metastases can be considered in selected patients for whom surgical resection of breast cancer liver metastases is not possible. But, of note, all studies that could be found on this subject were retrospective and lacked control groups, which makes it difficult to draw conclusions from their findings. Furthermore, no research has been done on the impact of the timing of metastasectomy.

\section{Conclusions}

This thesis discusses trends in the prognosis of patients with primary metastatic breast cancer and the impact of breast surgery on survival in this patient group. It also provides an overview on metastasectomy of liver and lung metastases in breast cancer.

The prognosis of patients with primary metastatic breast cancer has improved significantly during the last 5 to 10 years, especially for young women. This improvement is thought to be the result of the increased efficacy of chemotherapy and the introduction of targeted treatments.

Regional population-based cancer registry data indicates that resection of the primary tumor is associated with an improved survival. Consequently, this provides additional evidence that surgery of the breast tumor may improve the prognosis of breast cancer patients with metastatic disease at initial presentation. These results are in line with previous studies. Further, it seems unlikely that the prolonged survival after surgery could be explained by differences in the presence of symptomatic metastases between patients with and without surgery and by timing of surgery, demonstrated in additional research.

The role of breast surgery, however, remains unproven in the absence of randomized clinical trials. Thus, it is impossible to provide a definite answer to the question whether surgical resection of the breast tumor should be recommended for patients with primary metastatic breast cancer. A randomized controlled trial has been designed in order to analyze this properly in the near future.

Additionally, based on a review of the literature, it is concluded that metastasectomy of breast cancer liver or lung metastases may be considered in selected patients in an attempt to prolong survival. 


\section{Future perspectives}

Initiation and realization of randomized controlled trials on the effect of surgery of the breast tumor in patients with primary metastatic breast cancer will be very important in the near future. Different study groups from all over the world have committed themselves to this task, but it will take another 5 to 10 years before the results will come available.

Recently, in Austria (May 2010) and in the United States (February 2011) randomized controlled trials on this subject were initiated. The designs of these studies are largely similar to the design of the Dutch SUBMIT-trial, comparing up front surgery of the breast tumor immediately followed by systemic therapy with systemic therapy alone. The most important differences relate to the advice for locoregional radiotherapy. In the American study all patients treated with breast conserving surgery (BCS) will be receiving locoregional radiotherapy postoperatively. In the Austrian study, radiotherapy is not mandatory, whereas in the SUBMIT study protocol use of additional locoregional radiotherapy is left to the discretion of the responsible physician. Results of these studies are expected between 2014 and 2019. ${ }^{1}$

In the mean time, it would be interesting to investigate the biological mechanisms of the effect of surgery of the breast tumor on survival. The association between margin status and survival may indicate that tumors with positive margins have a more aggressive behaviour and therefore also result in a worse survival. One theory on the rationale of the effect of surgery is that surgery lowers the tumor load and therefore reduces the number of circulating tumor cells (CTCS) in the blood, which may be an important source of new metastatic deposits. Other hypotheses are that removal of the primary tumor restores the immune system and improves the nutritional status of the patient. Tumor-induced immunosuppression is a mechanism allowing tumors to escape immune destruction. It is thought that immunosuppression intensifies with increasing tumor burden. Surgery reduces the quantity of immunosuppressive factors, allowing the immune response to recover. ${ }^{2}$

Among others, it would be interesting to analyze the impact of tumor resection on CTCS, as previous prospective studies have shown that the number of CTCs before treatment is an independent predictor of overall survival in patients with metastatic breast cancer. $^{3-5}$

Randomized controlled trials are also indicated to provide more solid evidence for the effectiveness of resection of lung and liver metastases in breast cancer patients. Such trials are also important to define which patients may benefit from metastasectomy. At this moment, only literature on metastasectomy in patients with secondary metastatic breast cancer is available. In the future it would be interesting to see whether surgery of metastases has a place in the treatment of primary metastatic breast cancer as well, in order to prolong survival. 


\section{References}

1. clinicaltrials.gov

2. Danna EA, Sinha P, Gilbert M, Clements VK, Pulaski BA, Ostrand-Rosenberg S. Surgical removal of primary tumor reverses tumor-induced immunosuppression despite the presence of metastatic disease. Cancer. Res 2004;64:2205-2211

3. Budd GT, Cristofanilli M, Ellis MJ, Stopeck A, Borden E, Miller MC, Matera J, Repollet M, Doyle GV, Terstappen LWMM, Hayes DF. Circulating tumor cells versus imaging - predicting overall survival in metastatic breast cancer. Cancer Res. 2006;12:6403-6409

4. Cristofanilli M, Budd GT, Ellis MJ, Stopeck A, Matera J, Miller MC, Reuben JM, Doyle GV, Allard WJ, Terstappen LW, Hayes DF. Circulating tumor cells, disease progression, and survival in metastatic breast cancer. N Engl J Med. 2004;351:781-791

5. Cristofanilli M, Hayes DF, Budd GT, Ellis MJ, Stopeck A, Reuben JM, Doyle GV, Matera J, Allard WJ, Miller MC, Fritsche HA, Hortobagyi GN, Terstappen LW. Circulating tumor cells: a novel prognostic factor for newly diagnosed metastatic breast cancer. J Clin Oncol. 2005;23:1420-1430 
NEDERLANDSE SAMENVATTING, CONCLUSIES EN TOEKOMSTIGE ONTWIKKELINGEN 


\section{Samenvatting}

Bij ongeveer $5 \%$ van alle patiënten bij wie een invasief mammacarcinoom wordt vastgesteld, blijkt de ziekte op het moment van diagnose reeds te zijn uitgezaaid naar plekken elders in het lichaam. Dit wordt aangeduid als primair gemetastaseerd mammacarcinoom. Momenteel ondergaat het merendeel van de patiënten met een primair gemetastaseerd mammacarcinoom geen borstoperatie. Gedurende de laatste 10 jaar zijn verschillende observationele studies gepubliceerd waarin het verwijderen van de primaire tumor bij deze patiëntengroep geassocieerd bleek te zijn met een overlevingsvoordeel. Deze waarneming is meer in detail bestudeerd en beschreven in dit proefschrift. Daarnaast is het mogelijke voordeel van een chirurgische behandeling van metastasen van borstkanker bij patiënten met secundair gemetastaseerd mammacarcinoom bestudeerd, in het bijzonder van lever- en longmetastasen. Dit betreft patiënten bij wie de metastasen zich ontwikkelen in de jaren na de behandeling van het mammacarcinoom.

In hoofdstuk 2 is de prognose van meer dan 8000 patiënten met een primair gemetastaseerd mammacarcinoom geanalyseerd aan de hand van de gegevens van de Nederlandse Kanker Registratie. De patiënten werden onderverdeeld in drie perioden, afhankelijk van het diagnosejaar van hun ziekte, om zo te bestuderen of er een verbetering in de prognose was opgetreden.

De mediane overleving van patiënten met primair gemetastaseerde ziekte verbeterde tussen 1995 en 2008 van 1,42 tot 1,95 jaar. Deze verbetering was het meest uitgesproken bij patiënten onder de 50 jaar. Patiënten die systemische therapie, locoregionale radiotherapie of chirurgie van de mammatumor hadden ondergaan, lieten een significant lager risico op overlijden zien in vergelijking met patiënten die deze behandelingen niet hadden gekregen.

Het verbeterde effect van chemotherapie en de introductie van trastuzumab en andere doelgerichte therapie (targeted therapy) zijn de meest logische verklaringen voor de verbeterde prognose. Deze veronderstelling wordt ondersteund door het feit dat het overlevingsvoordeel groter was bij jongere patiënten, waarvan een groter deel behandeld bleek te zijn met doelgerichte therapie.

De resultaten van een populatieonderzoek zijn gepresenteerd in hoofdstuk 3. Het effect van een operatie van de mammatumor op de overleving werd onderzocht bij patiënten met een primair gemetastaseerd mammacarcinoom. Voor deze studie is gebruik gemaakt van de gegevens van de kankerregistratie van het Integraal Kankercentrum Zuid (IKZ). Er werden 728 patiënten geïncludeerd met gemetastaseerd mammacarcinoom bij initiële presentatie, gediagnosticeerd tussen 1993 en 2004 in Zuid-Nederland. Tweehonderdachtentachtig patiënten (40\%) waren behandeld met chirurgie van de mammatumor. Het percentage chirurgisch behandelde patiënten 
daalde van $55 \%$ in de periode $1993-1996$ tot $39 \%$ in de periode $1997-2000$ en tot $30 \%$ in de periode 2001-2004 $(P<0,0001)$.

De mediane overleving van patiënten die chirurgie van de primaire tumor hadden ondergaan was significant langer dan van patiënten die niet behandeld waren met een operatie (31 vs. 14 maanden). De 5-jaarsoverleving was respectievelijk $24,5 \%$ en $13,1 \%(P<0,0001)$. In een multivariate Cox regressieanalyse, gecorrigeerd voor leeftijd, periode van diagnose, T-classificatie, aantal locaties van metastasen, comorbiditeit, locoregionale radiotherapie en systemische therapie, bleek dat chirurgie een onafhankelijke prognostische factor was voor overleving, met een hazard ratio van 0,62 (95\% Cl 0,56-0,71). Patiënten die een okselklierdissectie ondergingen toonden een trend tot betere overleving in vergelijking met patiënten die geen okselklierdissectie hadden ondergaan. Echter dit verschil was alleen merkbaar in het eerste jaar na behandeling. Helaas was het niet bekend of er sprake was van een complete resectie of van tumorpositieve resectieranden.

Aan de hand van deze resultaten is er geconcludeerd dat resectie van de mammatumor bij patiënten met primair gemetastaseerd mammacarcinoom is geassocieerd met een verlaging van het mortaliteitsrisico van $40 \%$. Deze resultaten zijn vergelijkbaar met ander observationeel onderzoek en levert aanvullend bewijs in het voordeel van chirurgie.

De uitkomsten die beschreven zijn in hoofdstuk 3 resulteerden in aanvullende vragen, vooral met betrekking tot de rol van confounders en de invloed van een complete resectie van de primaire tumor op de overleving. Daarom is het effect van symptomatische metastasen en de timing van chirurgie, beiden potentiële confounders van het effect van chirurgie, onderzocht in hoofdstuk 4 . Tevens is het verschil van een complete resectie ten opzichte van positieve resectieranden bij een chirurgische behandeling op de overleving onderzocht. Om de invloed van deze mogelijke confounders te analyseren, zijn de individuele statussen van 279 patiënten met primair gemetastaseerd mammacarcinoom geanalyseerd.

Vierentachtig patiënten (30\%) ondergingen een operatie van de mammatumor als onderdeel van de behandeling. De mediane overleving van deze patiënten was 39 maanden, in vergelijking met 15 maanden voor die patiënten die geen chirurgie hadden ondergaan $(P<0,0001)$. Patiënten die waren behandeld met een operatie hadden minder vaak metastasen op meer dan één locatie.

Patiënten die zich presenteerden met symptomatische metastasen $(n=112)$ hadden vaker huidmetastasen en metastasen in het centrale zenuwstelsel. Zij werden minder vaak behandeld met chirurgie van de mammatumor in vergelijking met patiënten zonder symptomatische metastasen. De mediane overleving van patiënten met symptomatische metastasen was 19 maanden en voor patiënten zonder symptomatische metastasen was de mediane overleving 22 maanden $(P=0,15)$. 
Patiënten die een operatie van de primaire tumor ondergingen voordat de metastasen waren gediagnosticeerd $(n=43)$ hadden een significant kleinere primaire tumor, minder vaak een hormoonreceptorpositieve tumor, minder vaak botmetastasen en minder vaak symptomatische metastasen. Patiënten die behandeld waren met chirurgie van de primaire tumor op het moment dat de metastasen reeds waren gediagnosticeerd, hadden een mediane overleving van 38 maanden in vergelijking met 40 maanden voor degene waarbij de metastasen waren gediagnosticeerd nadat de operatie had plaatsgevonden $(P=0.81)$.

De mediane overleving van patiënten die een complete resectie hadden ondergaan was 41 maanden, in vergelijking met 28 maanden voor de patiënten met tumorpositieve resectieranden $(P=0,06)$.

Concluderend lijkt de aanwezigheid van symptomatische metastasen geen significante prognostische factor te zijn voor de overleving bij patiënten met een primair gemetastaseerd mammacarcinoom. Hetzelfde geldt voor de timing van chirurgie. Het is onwaarschijnlijk dat de verbeterde overleving na chirurgie wordt veroorzaakt door deze potentiële confounders. Daarnaast laten patiënten die chirurgisch behandeld waren met een complete resectie van de mammatumor een trend tot een betere overleving zien in vergelijking met patiënten met positieve tumormarges.

In de afgelopen jaren zijn er tien retrospectieve studies gepubliceerd over de invloed van chirurgie van de mammatumor op de prognose van patiënten met een primair gemetastaseerd mammacarcinoom. Deze studies zijn bediscussieerd en gezamenlijk geanalyseerd in hoofdstuk $\mathbf{5}$ om een beter inzicht te krijgen in het bewijs voor en tegen het effect van chirurgie.

Een ruwe analyse, zonder correctie voor potentiële confounders, liet zien dat een chirurgische resectie van de mammatumor bij patiënten met een primair gemetastaseerd mammacarcinoom werd geassocieerd met een significant langere overleving in zeven van de tien studies. De overige drie studies toonden een trend tot een betere overleving. Chirurgie van de primaire tumor bleek een onafhankelijke voorspellende factor te zijn voor een betere overleving in de multivariate analyses van de individuele studies, met hazard ratio's die varieerden van 0,47 tot 0,71 . De berekende gepoolde hazard ratio voor mortaliteit was $0,65(95 \% \mathrm{Cl} 0,59-0,72)$ in het voordeel van de patiënten die behandeld waren met chirurgie. Twee studies hadden ook het effect van chirurgische marges onderzocht, waarbij één studie liet zien dat de verbetering in overleving alleen zichtbaar was bij patiënten die een complete resectie van de primaire tumor hadden ondergaan. De andere studie toonde dat het overlevingsvoordeel meer uitgesproken was bij de patiënten die een complete resectie hadden gehad.

Drie van de tien studies concludeerden dat chirurgie niet gerelateerd was aan een verbeterde overleving en dat het geobserveerde voordeel was beïnvloed door confounders zoals "stage migration bias", selectiebias en coderingsfouten. 
Naast chirurgie waren er verschillende andere factoren die bijdroegen aan een betere overleving, zoals jonge leeftijd, kleine primaire tumor en metastasen op maar één locatie. In de meeste studies die waren geïncludeerd in de systematische review werd voor deze factoren gecorrigeerd door middel van een multivariate analyse. Echter, niet-gerandomiseerde studies staan altijd bloot aan het gevaar van "confounding by indication", wat inhoudt dat de associatie kan worden beïnvloed door andere prognostische factoren die samenhangen met de keuze voor chirurgie, maar die niet zijn gemeten of waarvan nog niet bekend is dat het confounders zijn.

De literatuur review laat zien dat chirurgie van de borsttumor bij patiënten met primair gemetastaseerd mammacarcinoom een positief effect heeft op de overleving. Tevens wordt er geconcludeerd dat, om een definitief antwoord te verkrijgen op de vraag of chirurgie van de mammatumor de overleving verbetert, gerandomiseerd onderzoek nodig is. Daarbij dient systemische therapie met en zonder chirurgie van de primaire tumor met elkaar te worden vergeleken.

De SUBMIT-studie is een gerandomiseerde klinische trial, die is opgezet om de invloed van potentiële confounders, waaraan alle observationele studies hebben blootgestaan, te elimineren. In hoofdstuk $\mathbf{6}$ is het protocol van deze studie gepresenteerd. SUBMIT is een acroniem voor "Systemic therapy with or without Up front surgery of the primary tumor in Breast cancer patients with distant Metastases at Initial presenTation". Deze trial zal uitgevoerd worden om te evalueren of chirurgie van de mammatumor bij patiënten met een primair gemetastaseerd mammacarcinoom de prognose zal verbeteren. Verder zal worden geanalyseerd of primaire chirurgie de lokale tumorcontrole verbetert (in vergelijking met systemische therapie alleen). Tevens zal de kwaliteit van leven worden onderzocht. Er zullen rond de $\mathbf{5 0 0}$ patiënten worden gerandomiseerd voor primaire chirurgie van de mammatumor gevolgd door systemische therapie, of voor systemische therapie gevolgd door uitgestelde lokale behandeling van de borsttumor op indicatie.

Patiënten die gerandomiseerd zijn voor chirurgie kunnen, afhankelijk van patiënt- en tumorkarakteristieken, zowel met een borstsparende ingreep of een ablatio mammae behandeld worden. Beide types chirurgie kunnen uitgevoerd worden, zolang de intentie maar een complete resectie is. De keuze voor een okselklierdissectie is de verantwoordelijkheid van de behandelend arts, maar dit wordt sterk geadviseerd als er sprake is van palpabele en/of tumor positieve lymfeklieren in de okselregio. Als de patiënt wordt gerandomiseerd voor systemische therapie dan is mammachirurgie in het geval van lokale progressie toegestaan. In twee gevallen kan gebruik gemaakt worden van radiotherapie. Ten eerste in het geval van een incomplete chirurgische verwijdering van de mammatumor. Ten tweede bij lokale progressie bij patiënten die gerandomiseerd zijn voor systemische therapie, als verondersteld wordt dat zij meer baat hebben bij lokale radiotherapie ten opzichte van chirurgie. Ook radiotherapie van de oksel in het geval van een klinisch positieve oksel kan worden overwogen als 
alternatief voor okselchirurgie. Alle patiënten zullen worden behandeld met systemische therapie volgens de richtlijnen van het Nationaal Borstkanker Overleg Nederland (NABON).

Het primaire eindpunt voor deze studie is de 2-jaarsoverleving. Kwaliteit van leven en lokale tumor controle zijn belangrijke secundaire eindpunten.

In hoofdstuk 7 werd een overzicht gegeven, gebaseerd op een systematische review, van het effect van chirurgie van lever- en longmetastasen bij patiënten met secundair gemetastaseerd mammacarcinoom. Een klein deel van alle patiënten met borstkanker ontwikkelt levermetastasen zonder extrahepatische ziekte. Hun mediane overleving is 19 tot 26 maanden als zij behandeld worden met systemische therapie. Studies naar chirurgie van levermetastasen rapporteerden een betere mediane overleving variërend van 27 tot 63 maanden en een 5-jaarsoverleving variërend tussen de 21 en $61 \%$. In de studies met radiofrequentie ablatie was de mediane overleving 2,5 tot 5 jaar.

In het algemeen is de mediane overleving in het geval van geïsoleerde longmetastasen ten gevolge van borstkanker 13 tot 25 maanden. De studies over chirurgie van longmetastasen lieten zien dat de overleving in het geval van chirurgie langer was, met een mediane overleving van 32 tot 76 maanden. De 5-jaarsoverleving varieerde tussen de 31 en $54 \%$.

De studies betreffende chirurgie van lever- en longmetastasen rapporteerden lage risico's op chirurgie gerelateerde morbiditeit en mortaliteit. Belangrijke factoren voor het overwegen van chirurgie van metastasen waren: jonge leeftijd, een lang ziektevrij interval en een klein aantal metastasen. De beste resultaten werden behaald met een combinatie van systemische therapie en chirurgie. Het was algemeen geaccepteerd dat alle patiënten met systemische therapie behandeld werden.

In het geval van metastasen van het femur en de wervels werd chirurgie alleen ingezet om pathologische fracturen te voorkomen of te behandelen.

Er wordt geconcludeerd dat chirurgie van lever- en longmetastasen bij patiënten met mammacarcinoom zou kunnen worden uitgevoerd bij een geselecteerde groep patiënten in een poging de overleving te verbeteren. Het gebruik van minimaal invasieve technieken om levermetastasen te behandelen kan worden overwogen als chirurgische resectie van de metastasen niet mogelijk lijkt te zijn. Een kanttekening bij dit onderzoek is dat alle beschikbare studies retrospectieve, niet-gerandomiseerde onderzoeken zijn zonder controlegroepen. Dit maakt het moeilijk om conclusies te trekken. Daarnaast is er geen literatuur gevonden over het effect van de timing van chirurgie van de metastasen. 


\section{Conclusies}

Dit proefschrift behandelt de trends in de prognose van patiënten met primair gemetastaseerd mammacarcinoom en het effect van een operatieve behandeling van de mammatumor op de overleving van deze patiëntengroep. Het geeft tevens een overzicht van chirurgie van lever- en longmetastasen bij patiënten met mammacarcinoom.

Gegevens van de Nederlandse Kanker Registratie laten zien dat de prognose van patiënten met primair gemetastaseerd mammacarcinoom aanzienlijk is verbeterd in de afgelopen 5 tot 10 jaar en dat dit met name geldt voor jonge vrouwen. Deze verbetering is waarschijnlijk veroorzaakt door de verbeterde effectiviteit van chemotherapie en de introductie van trastuzumab (en andere targeted therapy).

Aan de hand van regionaal populatieonderzoek in Zuid-Nederland, gebaseerd op gegevens van de kankerregistratie van het Integraal Kankercentrum Zuid, is er geconcludeerd dat resectie van de primaire tumor geassocieerd is met een verbeterde overleving. Dit levert aanvullend bewijs dat chirurgie van de mammatumor de prognose van patiënten met metastasen bij de initiële presentatie zou kunnen verbeteren. Tevens zijn deze resultaten vergelijkbaar met de resultaten van eerdere studies. Verder is er aangetoond dat het onwaarschijnlijk is dat de verbeterde overleving zou kunnen worden veroorzaakt door een verschil in de aanwezigheid van symptomatische metastasen tussen patiënten die wel en niet behandeld zijn met chirurgie en door de timing van chirurgie.

Echter, door het ontbreken van gerandomiseerde studies is de rol van chirurgie niet onomstotelijk bewezen. Daarom is het onmogelijk om een definitief antwoord te geven op de vraag of chirurgie van de mammatumor aanbevolen zou moeten worden aan patiënten met een primair gemetastaseerd mammacarcinoom. Een gerandomiseerde studie om dit goed te onderzoeken is recentelijk in Nederland opgezet.

Aanvullend, aan de hand van een review van de literatuur, kan worden geconcludeerd dat chirurgie van lever- en longmetastasen overwogen kan worden bij een geselecteerde groep patiënten om zo te pogen de overleving te verbeteren.

\section{Toekomstige ontwikkelingen}

Het is zeer belangrijk om in de nabije toekomst gerandomiseerd onderzoek te initiëren naar het effect van chirurgie van de mammatumor bij patiënten met primair gemetastaseerd mammacarcinoom. Verschillende onderzoeksgroepen over de hele wereld hebben zich toegelegd op de uitvoering van dergelijke studies. Het zal waarschijnlijk nog 5 tot 10 jaar duren voordat de resultaten van deze studies beschikbaar komen. 
Onlangs zijn in Oostenrijk (mei 2010) en de Verenigde Staten (februari 2011) studies vergelijkbaar aan de SUBMIT-trial opgezet en gestart. De opzet van deze studies komt overeen met het design van de SUBMIT-trial, waarbij chirurgie van de mammatumor en systemische therapie wordt vergeleken met systemische therapie alleen. Het belangrijkste verschil betreft het gebruik van locoregionale radiotherapie. In de Amerikaanse studie krijgen alle patiënten die behandeld worden met borstsparende therapie postoperatief locoregionale radiotherapie. In de Oostenrijkse studie is dit niet verplicht en in het SUBMIT studieprotocol wordt de behandelaar vrij gelaten in de keuze voor eventuele postoperatieve locoregionale radiotherapie. De resultaten van deze studies worden verwacht tussen 2014 en $2019 .^{1}$

In de tussentijd is het interessant om een biologische verklaring te zoeken die het effect van chirurgie van de primaire tumor op de overleving zou kunnen verduidelijken. De samenhang tussen een complete resectie en overleving zou kunnen betekenen dat tumoren met positieve marges een agressiever gedrag vertonen en daardoor een slechtere overleving hebben. Een theorie over het effect van chirurgie is dat de verminderde tumorload resulteert in een afname van het aantal circulerende tumorcellen (CTCS) in het bloed, die een belangrijke bron zouden kunnen zijn van nieuwe metastasen. Andere hypothesen zijn dat het verwijderen van de primaire tumor het immuunsysteem herstelt en dat het de voedingsstatus van de patiënt verbetert. Tumorgeïnduceerde immuunsuppressie is een mechanisme dat er voor zorgt dat tumoren kunnen ontsnappen aan het immuunsysteem. Er wordt gedacht dat die immuunsupressie versterkt met het groeien van de tumor en/of metastasen. Daardoor zou chirurgie de hoeveelheid immunosupressieve factoren kunnen verminderen en zou de normale immuunrespons kunnen herstellen. ${ }^{2}$ Het is onder andere interessant om te analyseren wat het effect van tumorresectie zal zijn op het aantal circulerende tumorcellen, omdat eerdere prospectieve studies naar CTCs hebben laten zien dat het aantal CTCs voor de behandeling een onafhankelijke voorspeller is van de overleving bij patiënten met gemetastaseerd mammacarcinoom. $^{3-5}$

Gerandomiseerd onderzoek is tevens nodig voor het verkrijgen van meer gefundeerd bewijs van het effect van resectie van lever- en longmetastasen bij patiënten met gemetastaseerd mammacarcinoom. Dat zal ook belangrijk zijn om te bepalen welke patiënten voordeel kunnen hebben bij resectie van de metastasen. Op dit moment is er alleen literatuur beschikbaar over chirurgie van metastasen bij patiënten met secundair gemetastaseerd mammacarcinoom. Het is relevant om te onderzoeken of resectie van metastasen tevens een rol kan spelen in de behandeling van patiënten met primair gemetastaseerd mammacarcinoom om ook op die manier hun overleving te kunnen verbeteren. 


\section{References}

1. clinicaltrials.gov

2. Danna EA, Sinha P, Gilbert M, Clements VK, Pulaski BA, Ostrand-Rosenberg S. Surgical removal of primary tumor reverses tumor-induced immunosuppression despite the presence of metastatic disease. Cancer. Res 2004;64:2205-2211

3. Budd GT, Cristofanilli M, Ellis MJ, Stopeck A, Borden E, Miller MC, Matera J, Repollet M, Doyle GV, Terstappen LWMM, Hayes DF. Circulating tumor cells versus imaging - predicting overall survival in metastatic breast cancer. Cancer Res. 2006;12:6403-6409

4. Cristofanilli M, Budd GT, Ellis MJ, Stopeck A, Matera J, Miller MC, Reuben JM, Doyle GV, Allard WJ, Terstappen LW, Hayes DF. Circulating tumor cells, disease progression, and survival in metastatic breast cancer. N Engl J Med. 2004;351:781-791

5. Cristofanilli M, Hayes DF, Budd GT, Ellis MJ, Stopeck A, Reuben JM, Doyle GV, Matera J, Allard WJ, Miller MC, Fritsche HA, Hortobagyi GN, Terstappen LW. Circulating tumor cells: a novel prognostic factor for newly diagnosed metastatic breast cancer. J Clin Oncol. 2005;23:1420-1430 
DANKWOORD 


\section{Dankwoord}

Dit proefschrift is het resultaat van het opzetten van een multicenter gerandomiseerde studie in Nederland en de tijd die dat in beslag heeft genomen. Ik ben een enthousiaste onderzoeker geworden en dit is eigenlijk pas het begin nu de SUBMIT studie van start is gegaan.

Ik ben iedereen erg dankbaar voor alle hulp en het getoonde vertrouwen in een goed resultaat.

Geachte Prof. dr. Tjan-Heijnen, beste Vivianne. Ontzettend bedankt dat jij als medisch oncoloog de promotor wilde zijn van dit chirurgische proefschrift. Jij heb je fantastisch ingezet. Allereerst door er voor te waken dat het design van de SUBMIT studie zo simpel (chirurgisch) mogelijk werd gehouden. Daarnaast met de begeleiding tijdens het opzetten van de studie: voor ons een bijzonder groot project. Zonder jouw ervaring was het niet gelukt. Zo snel jij was met het reviseren van mijn stukken, zo laat hoorde je dat ik was aangenomen voor de opleiding tot chirurg, ik had je gesmst... (maar dat lees je dus niet). Een kaart was beter geweest, dat had ik moeten weten.

Miranda! Dr. M.F. Ernst. Allereerst veel dank voor de gezellige (onderzoeks)tijd en de gastvrijheid bij jullie thuis. Schrijven is een stuk leuker als je het samen doet! Ik zou het bijzonder vinden als we dat blijven doen. Het proefschrift is er als vanzelf gekomen, tijdens het opzetten van onze studie. Heel erg bedankt voor je optimistische houding tijdens de hobbels op weg naar de start van SUBMIT. Stockholm was voor mij een kroon op al het werk, bedankt dat je daar bij was.

Beste Adri, dr. A.C. Voogd. Jouw ervaring was zeer waardevol tijdens het schrijven van alle stukken. We hebben veel heen en weer gemaild en samen revisies geschreven. Of ik toch niet ook in het Catharina Ziekenhuis de statussen in wilde duiken, een groter patiëntenaantal zou het artikel namelijk ten goede komen... Natuurlijk had je gelijk. Bedankt voor al je goede raad.

Graag wil ik de leden van de beoordelingscommissie, te weten Prof. dr. M.F. von Meyenfeldt, dr. P.S.G.J. Hupperets en Prof. dr. M.H. Prins hartelijk danken voor het beoordelen van mijn proefschrift.

Mijn paranimfen, Anne en Henrieke. Dank voor jullie onvermoeide interesse in de voortgang van mijn onderzoek en proefschrift en nog meer voor de bijstand op de dag zelf! Ik waardeer het enorm dat jullie de komst van de baby's voor en na mijn promotie hebben gepland. 
Beste oud-collega's van het Jeroen Bosch Ziekenhuis. Een betere start binnen de chirurgie had ik me niet kunnen wensen. De gezelligheid heeft er mede voor gezorgd dat ik meer dan drie jaar bij jullie heb gewerkt (leuk al die congressen!). Ik ben blij dat ik naast het werken in de kliniek de kans heb gekregen zulk productief onderzoek te verrichten.

Beste collega's van het Máxima Medisch Centrum. Dank voor alle weekjes schijftijd! Zie hier wat er van geworden is. Ik ben blij dat ik mijn opleiding heb kunnen starten in deze leerzame kliniek waar ik zo gastvrij ben ontvangen. Nu heb ik tijd om (nog meer) te opereren!

Boukje, samen uit, samen thuis. Dank voor al je handige adviezen. We zijn weer collega's, nu allebei in opleiding!

Lieve dames van Geneeskunde, zelfde studie, maar allemaal een andere weg. Ondanks de drukke agenda's staan jullie er nog steeds in. Ik kom jullie onderweg graag tegen!

Bliksem. Veel ploeghappen, weinig roeien, nog steeds heel veel lol.

Lieve Lotte, vanuit de Verenigde Staten altijd interesse naar mijn onderzoek en bijzondere verhalen over de chirurgische wereld aan de andere kant van de oceaan (van Trac). Niet altijd correct, maar dat levert mooie verhalen op; gedwongen sectio's voor vrouwelijke assistenten hoofd-hals chirurgie? In ieder geval hebben we het in Nederland niet slecht met betrekking tot de werktijden.

Lieve Janneke, soms lijkt Zeeland ook zo ver weg, maar gelukkig zijn en komen er genoeg gebeurtenissen, zoals Femke, die er voor zorgen dat we elkaar zien of schrijven.

Lieve Jolijn en Eline, na de middelbare school belandden we alle drie in Maastricht, waar we meer onze eigen weg gingen dan op het Jordan. Gelukkig zie ik jullie en de kids vaak genoeg in Bilthoven of Leiden.

Lieve vriendinnetjes uit Wijk, Cora, Nicky en Mirelle. Ik wil jullie alle drie bedanken voor jullie interesse in mijn werk en nog meer voor de ontspanning en gezelligheid.

Lieve Fia en Wim, jullie zijn altijd onbevooroordeeld en vrij geweest in onze opvoeding, stimulerend en zeer geïnteresseerd. Jullie zijn een aanvulling op elkaar; Fia is de kliniek en Wim de wetenschap met betrekking tot mijn opleiding en mijn promotie. Ik kan mij geen betere combinatie wensen. 
Wigger, broertje! Jij bent altijd zo trots op mij (en dan bel je na een paar biertjes 's avonds laat om dat te vertellen). Erg lief. Jouw vriendin Patricia is een leuke schoonzus, ik kan het goed met haar vinden. Jullie geweldige dochter Tessa maakt mij zo vrolijk!

Ellen, mijn vrouw

Honey you are a rock

Upon which I stand

And honey you should know

That I could never go on without you

Green eyes ... 


\section{CURRICULUM VITAE}




\section{Curriculum vitae}

Jetske Ruiterkamp was born on the 3th of August 1981, in Utrecht, and raised in the nearby Wijk bij Duurstede. She attended high school at the Herman Jordan Lyceum in Zeist. After graduation she studied Health Sciences for two years, followed by the start of her medical training in 2001, both at the University of Maastricht. During her study she worked as research assistant at the Department of Biochemistry, which has been the start of her research career. Besides studying, she was involved in the development of the new curriculum of the Faculty of Medicine. In 2006 she received her doctorate cum laude and one and a half year later she obtained her medical degree (2007). She worked as surgical resident at the Jeroen Bosch Hospital in 'sHertogenbosch. The research on surgery of the primary tumor in breast cancer patients with metastatic disease has started there, supervised by Miranda Ernst, and has resulted in this thesis. She has presented her study results at several international congresses in that period, and she was invited speaker in September 2011 at the European Multidisciplinary Oncology Congress in Stockholm. In January 2011 she started as a resident in training to become a surgeon at the Máxima Medical Centre in Veldhoven, part of the educational region of the University Medical Centre Nijmegen. In September 2011 she married Ellen Vunderink.

Jetske Ruiterkamp is geboren op 3 augustus 1981 te Utrecht en opgegroeid in het nabije Wijk bij Duurstede. Op het Herman Jordan Lyceum in Zeist heeft zij Montessori onderwijs genoten en haar VWO diploma behaald. Hierna heeft zij twee jaar Gezondheidswetenschappen gestudeerd waarna zij kon starten met de studie Geneeskunde in 2001, beide aan de universiteit van Maastricht. Tijdens haar studie werkte zij als student-assistent bij de Vakgroep Biochemie, waar de basis voor het doen van onderzoek gelegd is. Naast haar studie was zij betrokken bij de inhoud van het nieuwe curriculum van de faculteit Geneeskunde. In 2006 behaalde zij cum laude haar doctoraal en anderhalf jaar later ontving zij haar artsendiploma (2007). Zij ging werken als arts-assistent chirurgie in het Jeroen Bosch Ziekenhuis te 'sHertogenbosch. Het onderzoek naar chirurgie van de primaire tumor bij borstkankerpatiënten met gemetastaseerde ziekte is zij daar begonnen onder leiding van Miranda Ernst en heeft geresulteerd in dit proefschrift. In die periode heeft zij verscheidene keren haar onderzoeksresultaten op internationale congressen gepresenteerd en in september 2011 was zij genodigd spreker in Stockholm op het Europees Multidisciplinair Oncologiecongres. Zij is in januari 2011 begonnen met de opleiding tot chirurg in het Máxima Medisch Centrum in Veldhoven, in de opleidingsregio van het Universitair Medisch Centrum Nijmegen. In september 2011 is zij getrouwd met Ellen Vunderink. 
128 